\title{
CARACTERIZAÇÃO DA AÇÃO INIBITÓRIA DA CROTOXINA SOBRE AS FUNÇÕES DE CÉLULAS ENDOTELIAIS EM MATRIZ EXTRACELULAR BIDIMENSIONAL E TRIDIMENSIONAL. ESTUDOS IN VITRO
}

Dissertação apresentada ao Programa de PósGraduação em Farmacologia do Instituto de Ciências Biomédicas da Universidade de São Paulo, para obtenção do Título de Mestre em Ciências. 


\section{Ellen Emi Kato}

Caracterização da ação inibitória da Crotoxina sobre as funções de células endoteliais em matriz extracelular bidimensional e tridimensional.

Estudos in vitro

Dissertação apresentada ao Programa de PósGraduação em Farmacologia do Instituto de Ciências Biomédicas da Universidade de São Paulo, para obtenção do Título de Mestre em Ciências.

Área de concentração: Farmacologia

Orientadora: Sandra Coccuzzo Sampaio Vessoni

Versão original 
DADOS DE CATALOGAÇÃO NA PUBLICAÇÃO (CIP)

Serviço de Biblioteca e Informação Biomédica do

Instituto de Ciências Biomédicas da Universidade de São Paulo

reprodução não autorizada pelo autor

Kato, Ellen Emi.

Caracterização da ação inibitória da Crotoxina sobre as funções de células endoteliais em matriz extracelular bidimensional e tridimensional. Estudos in vitro. / Ellen Emi Kato. -- São Paulo, 2014.

Orientador: Profa. Dra. Sandra Coccuzzo Sampaio Vessoni.

Dissertação (Mestrado) - Universidade de São Paulo. Instituto de Ciências Biomédicas. Departamento de Farmacologia. Área de concentração: Farmacologia. Linha de pesquisa: Mecanismos moleculares envolvidos na ação de toxinas sobre processos fisiopatológicos.

Versão do título para o inglês: Characterization of inhibitory action of Crotoxin on endothelial cells function in two-dimensional and threedimensional extracellular matrix. In vitro studies.

1. Crotoxina 2. Células endoteliais 3. Matriz extracelular 4. Adesão 5. Migração 6. Integrinas I. Vessoni, Profa. Dra. Sandra Coccuzzo Sampaio II. Universidade de São Paulo. Instituto de Ciências Biomédicas. Programa de Pós-Graduação em Farmacologia III. Título. 
Título da Caracterização da ação inibitória da Crotoxina sobre as funções de células endoteliais em matriz extracelular bidimensional e tridimensional. Estudos in vitro.

Orientador(a):

Profa. Dra. Sandra Coccuzzo Sampaio Vessoni.

A Comissão Julgadora dos trabalhos de Defesa da Dissertação de Mestrado, em sessão pública realizada a considerou

\section{( ) Aprovado(a)}

( ) Reprovado(a)

Examinador(a): Assinatura:

Nome:

Instituição:

Examinador(a): Assinatura:

Nome:

Instituição:

Presidente: Assinatura:

Nome:

Instituição: 


\section{CERTIFICADO DE ISENÇÃO}

Certificamos que o Protocolo CEP-ICB N $\mathrm{N}^{\circ}$ 549/12 referente ao projeto intitulado: "Efeito da crotoxina sobre mecanismos envolvidos na adesão, proliferação e migração de célula endotelial em matriz extracelular bidimensional e tridimensional" sob a responsabilidade de Ellen Emi Kato, foi analisado na presente data pela CEUA - COMISSÃO DE ÉTICA NO USO DE ANIMAIS e pela CEPSH- COMISSÃO DE ÉTICA EM PESQUISA COM SERES HUMANOS, tendo sido deliberado que o referido projeto não utilizará animais que estejam sob a égide da lei 11.794 de 8 de outubro de 2008, nem envolverá procedimentos regulados pela Resolução CONEP nº196 de 1996.

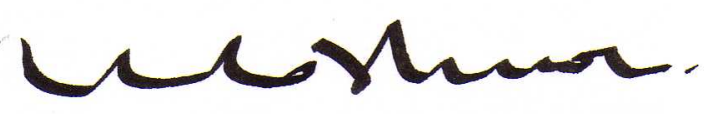

Prof. Dr. Wothan TAVARES DE Lima Coordenador da CEUA - ICB/USP
São Paulo, 30 de agosto de 2012.

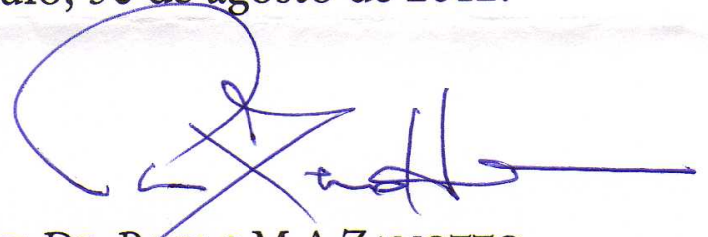

PROF. DR. PAOLO M.A ZANOTTO

Coordenador da CEPsh - ICB/USP 
São Paulo, 13 de setembro de 2012.

Protocolo: I-963/12

Dra. Sandra Coccuzzo Sampaio Vessoni Laboratório de Fisiopatologia

Instituto Butantan

Referente Projeto: "Efeito da crotoxina sobre mecanismos envolvidos na adesão, proliferação e migração de célula endotelial em matriz extracelular bidimensional e tridimensional".

A Comissão de Ética no Uso de Animais do Instituto Butantan (CEUAIB) informa que o projeto acima referido é isento de análise por parte desta Comissão, pois não faz uso de animais vertebrados em sua execução.

Cordialmente,

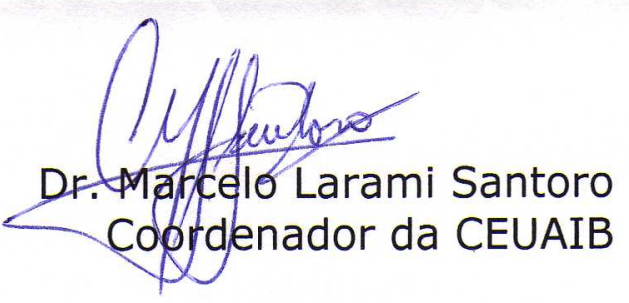


$\grave{A}$ minha familia,

Aos meus país, Teresa e Roberto, e à minha irmã, Kelly, por todo amor, confíança, apoio, esforço e dedicação para que eu tívesse uma boa formação acadêmica. Vocês foram e sempre serão os meus pilares e minha principal fonte de força.

Ao meu amor, Pedro

Por todo amor, paciência, apoio, compreensão e companheirísmo em todos os momentos difíceis. Por sempre ter me incentivado a seguir em frente, em tentar e nunca desistir dos meus objetivos.

À minha querida tía Rosa (in memorian), Mesmo de longe, sempre me deu apoí, incentivo e muitas orações para que tudo desse certo na minha vida. Hoje tenho certeza, de onde ela estiver, ela está feliz com essa conquista! 


\section{AGRADECIMENTOS}

À minha orientadora, Sandra Coccuzzo Sampaio Vessoni, obrigada pela oportunidade de ser sua aluna, pelo aprendízado, compreensão e paciêncía, por ter acredítado e confíado em mím desde o começo e sempre mostrar que sou capaz. Você é muito maís que orientadora, é exemplo de profissional e pessoa que eu admiro e me inspiro.

À minha co-orientadora, Maíra Estanislau Soares de Almeida, obrigada por toda paciência, por compartilhar seu conhecimento comigo, pelas discussões científicas, pela colaboração no projeto e pelo apoío e suporte nos momentos difíceís. Pode ter certeza que aprendi e muito com você!

À professora Marinilce dos Santos, obrigada pela colaboração no projeto, confiança e por ceder o laboratório para eu realizar boa parte dos experimentos.

À Vanessa Zambelli, que na última etapa do projeto tive a grande oportunidade de aprender a técnica de Western Blotting, obrigada pelo conhecimento, confiança, paciencia e por ter dado liberdade e espaço para eu padronizar as amostras.

Ao grupo, Edilene, Renatinha, Luciana e Jaqueline, obrigada pelo suporte, apoio, conversas e companheirismo. Aprendi e amadureci profíssionalmente com vocês.

Aos funcionários e pesquisadores do Laboratório de Fisiopatología e do Laboratório Especializado em Dor e Sinalização do Instituto Butantna e do Laboratório de Biología do Movimento Celular do ICB/USP, obrigada pelo suporte técnico.

À secretáría do Programa de Pós-Graduação, Mônica Nunes, pela competencia, auxilio e disposição para ajudar.

Aos meu familiares pelo apoio e incentivo, em especial à tía Elena e ao tio Katsunorí.

Aos meus amigos, pela compreensão da minha ausêncía, pelo apoio e por sempre torcerem por mim. Obrigada!

Ao apoio financeiro do CNPq (Processo $n^{0}$ 132761/2012-2) e FAPESP (Processo $n^{0}$ 2012/51241-5) 
"Throughout the years

I have struggled to find

the answer that I never knew

It struck me like a million lightnings

and here I am telling to you"

("Destiny" - Stratovarius,

Compositor: Timo Tolkki) 
"Foi o tempo que dedícaste à tua rosa que fez tua rosa tão importante" (Antoine de Saint-Exupéry) 


\section{RESUMO}

KATO, E. E. Caracterização da ação inibitória da Crotoxina sobre as funções de células endoteliais em matriz extracelular bidimensional e tridimensional: estudos in vitro. 2014 . 76 f. Dissertação (Mestrado em Farmacologia) - Instituto de Ciências Biomédicas, Universidade de São Paulo, São Paulo, 2014.

Diversos estudos, in vivo e in vitro, demonstraram a atividade antitumoral da Crotoxina (CTX), toxina majoritária do veneno de serpente Crotalus durissus terrificus. A angiogenese é um evento-chave nos processos da tumorigênese e da metástase. Apesar das evidências da ação antitumoral da CTX, não foi demonstrado, até o momento, a ação desta toxina sobre eventos envolvidos com a neovascularização, essenciais para o crescimento e sobrevivência do tumor. Assim, estudos demonstrando a ação da CTX sobre parâmetros fundamentais para a neovascularização podem contribuir com a caracterização da ação antitumoral da CTX. Neste estudo, foi investigado o efeito in vitro da CTX sobre a angiogênese. Para tanto, a linhagem de células endoteliais murinas derivados do hemangioma do timo (t.End.1) foram tratadas em diferentes concentrações de CTX $(0,15 \mu \mathrm{g} / \mathrm{mL}$ a $4,8 \mu \mathrm{g} / \mathrm{mL})$ e a proliferação, adesão e a morfologia das células endoteliais sobre as matrizes de laminina $(10 \mu \mathrm{g} / \mathrm{mL})$, colágeno tipo I $(10 \mu \mathrm{g} / \mathrm{mL})$ e fibronectina $(3 \mu \mathrm{g} / \mathrm{mL})$, bem como a migração por meio dos modelos de cicatrização (Wound Healing), quimiotaxia (transwell) e a formação de tubos sobre matriz tridimensional (3-D) foram avaliados. Os resultados demonstraram efeito inibitório da CTX, principalmente na concentração de $1,2 \mu \mathrm{g} / \mathrm{mL}$, durante o tratamento de 1 hora, seguido da incubação em meio de cultura fresco, em diferentes tempos. CTX inibiu a proliferação celular, formação de tubos no matrigel 3-D, a migração celular avaliadas no modelo de cicatrização e quimiotaxia tanto na presença de meio de cultura como no meio condicionado de célula tumoral. Além disso, CTX inibiu a adesão celular o que pode ter contribuido para a diminuição na distribuição das subunidades de integrinas $\alpha \mathrm{v}$ e $\alpha 2$ e polimerização do citoesqueleto de actina, evidenciados em microscopia confocal. Esta ação inibitória não é decorrente da perda de viabilidade celular. Ainda, frente ao estímulo tumoral, alguns desses eventos analisados apresentaram-se mais inibidos após o pré-tratamento com a CTX. Pela primeira vez, é demonstrado que a CTX inibe os eventos cruciais envolvidos com o processo de angiogênese, os quais podem ser fundamentais para o efeito inibitório da toxina sobre a progressão tumoral.

Palavras-chave: Crotoxina. Célula endotelial. Matriz extracelular. Adesão. Migração. Integrinas. 


\begin{abstract}
KATO, E. E. Characterization of inhibitory action of Crotoxin on endothelial cells functions in two-dimensional and three-dimensional extracellular matrix: in vitro studies. 2014. 76 p. Masters thesis (Pharmacology) - Instituto de Ciências Biomédicas, Universidade de São Paulo, São Paulo, 2014.

Several studies, in vivo and in vitro have demonstrated antitumor activity of Crotoxin (CTX), the major toxin from Crotalus durissus terrificus snake venom. Angiogenesis, the development of new blood vessels, is essential for tumor growth and metastasis. Despite the evidences of antitumor action of CTX, it has been not demonstrated, until now, the action of this toxin on main events involved in neovascularization which is essential for tumor growth and survival. Thus, studies demonstrating the action of CTX on key parameters for neovascularization may contribute for characterization of antitumor action of CTX. In this study, the in vitro effect of CTX on angiogenesis was investigated. Murine endothelial cells line derived from thymus hemangioma (t.End.1) were treated at different concentrations of CTX $(0.15 \mu \mathrm{g} / \mathrm{mL}$ to $4.8 \mu \mathrm{g} / \mathrm{mL})$ and endothelial cell (EC) proliferation, adhesion and actin cytoskeleton on laminin $(10 \mu \mathrm{g} / \mathrm{mL})$, collagen type $\mathrm{I}(10 \mu \mathrm{g} / \mathrm{mL})$ and fibronectin $(3 \mu \mathrm{g} / \mathrm{mL})$ as well EC migration (scratch wound healing and chemotaxis assays) and formation of capillarylike tubes on matrigel were evaluated. The results have shown inhibitory effect of CTX, mainly at the concentration of $1.2 \mu \mathrm{g} / \mathrm{mL}$ during treatment for 1 hour. CTX inhibited the cell proliferation; tube formation on matrigel 3D, migration at wound healing and chemotaxis assays in the presence of culture medium or in tumor conditioned medium. Moreover, CTX inhibited cell adhesion which may have contributed to reduction of the $\alpha \mathrm{v}$ and $\alpha 2$ integrins distribution and cytoskeleton actin polymerization, analysed in confocal microscopy. The results of this study demonstrate that CTX inhibits key events involved in angiogenesis such as adhesion, proliferation, migration, tube formation, morphology and distribution of integrins on endothelial cells and this inhibition is not due to loss of cell viability. Additionally, this inhibitory effect being more pronounced against tumor stimulation in some of these events analyzed. In conclusion, it was demonstrated for the first time, that CTX inhibits key events involved in the angiogenesis process, and may contribute for inhibitory effect of the toxin on tumor progression.
\end{abstract}

Keywords: Crotoxin. Endothelial cells. Extracellular Matrix. Adhesion. Migration. Integrins. 


\section{LISTA DE FIGURAS}

Figura 1 - Estrutura Tetramérica da Crotoxina isolada do veneno de Crotalus durissus terrificus

Figura 2. Principais aspectos da sinalização intracelular mediada pelas integrinas ...... 26

Figura 3 -Efeito in vitro da CTX sobre a proliferação das células endoteliais t.End.1 ... 41

Figura 4 - Efeito da CTX sobre adesão celular em diferentes componentes de matriz extracelular

Figura 5 - Efeito da CTX sobre a migração da t.End.1 no modelo de Wound healing em diferentes períodos de tratamento

Figura 6 - Efeito da CTX sobre a migração celular avaliada no modelo de Wound healing após 24 horas de incubação em meio condicionado de cultura de célula tumoral

Figura 7 - Efeito d a CTX sobre a migração das células endoteliais avaliada no modelo de câmara de transwell

Figura 8 - Efeito da CTX sobre a formação de estruturas do tipo tubulares no matrigel

Figura 9 - Efeito da CTX sobre o citoesqueleto de actina e marcação das integrinas ..... 56

Figura 10 - Efeito da CTX sobre o citoesqueleto de actina e expressão da integrina $\alpha v$ sob fibronectina, na presença de meio condicionado de célula tumoral MCF-7 


\section{SUMÁRIO}

1 INTRODUÇÃ

1.1 Venenos de serpentes Crotalus durissus terrificus e suas toxinas isoladas.................. 15

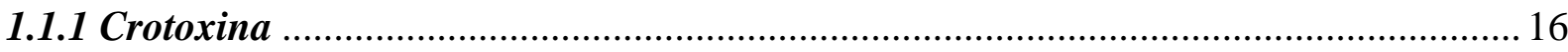

1.2 Estudos experimentais sobre os efeitos imunorregulatório, anti-inflamatório e antitumoral do veneno de Crotalus durissus terrificus (VCdt) e suas toxinas isoladas

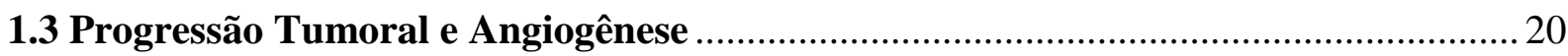

1.3.1 Interação entre célula endotelial e matriz extracelular na angiogênese ..................... 22

1.3.2 Adesão, proliferação e migração celular. Principais aspectos ................................... 23

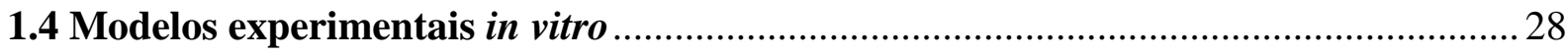

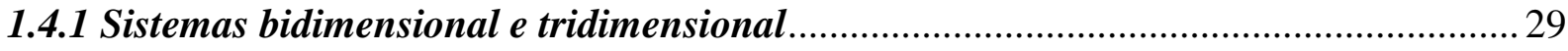

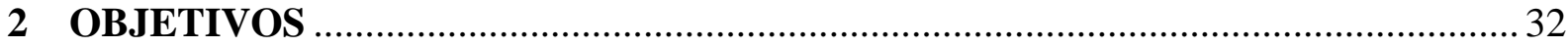

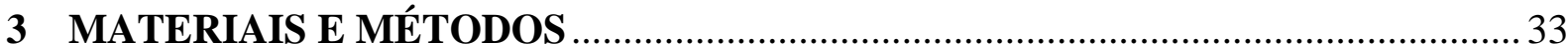

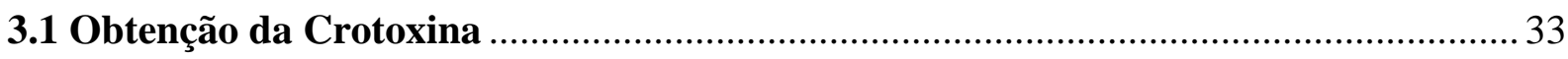

3.2 Obttenção do colégeno tipo I a partir da cauda de rato ........................................... 33

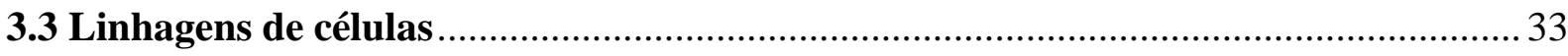

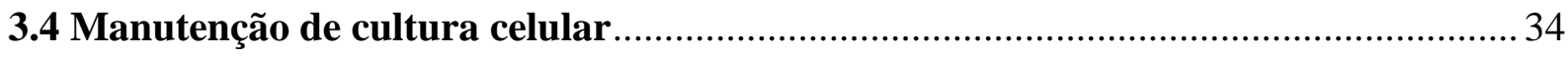

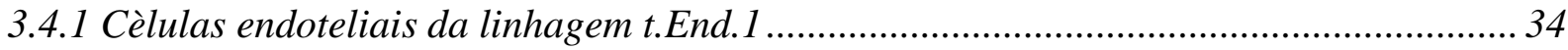

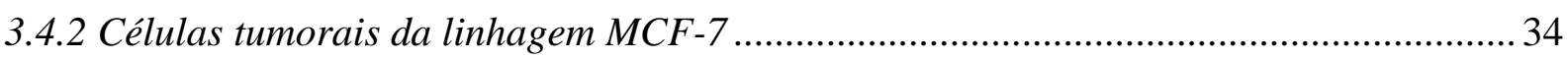

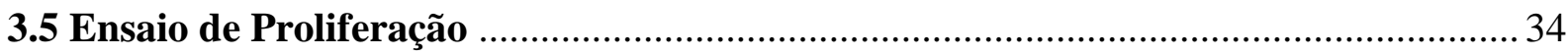

3.6 Efeito da CTX sobre a invasão da célula t.End.1 na matriz extracelular .................. 35

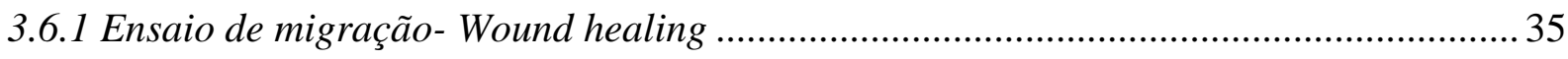

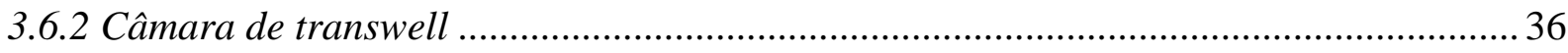

3.6.3 Ensaio de competição entre a célula endotelial e o ligante natural ............................... 37

3.7 Ensaio da formação de tubos em matrigel no modelo 3D .......................................... 38

3.8 Ensaio de imunofluorescencia para avaliar o efeito da CTX sobre as integrinas ...... 38

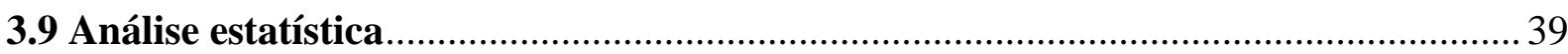

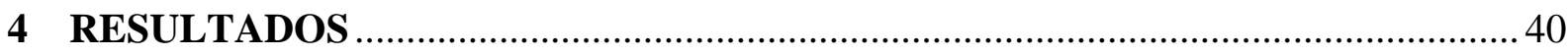

4.1 Efeito in vitro da CTX sobre a proliferação da célula endotelial (t.End.1) ............... 40

4.2 Efeito da CTX sobre a adesão de t.End.1 em diferentes ligantes da matriz extracelular. 
4.3 Efeito da CTX na migração da célula endotelial ....................................................... 44

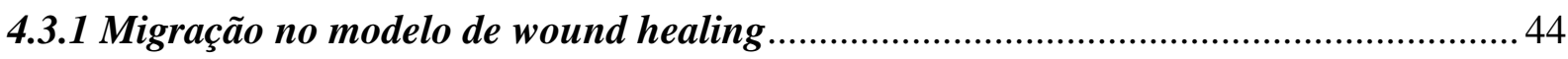

4.3.2 Migração no modelo de wound healing induzida por estímulo tumoral ..................... 47

4.3.3 Efeito da CTX sobre a quimiotaxia no modelo de câmara de transwell ...................... 50

4.4 Efeito da CTX sobre a formação de estruturas capilares in vitro no matrigel 3D ..... 53

4.5 Efeito da CTX sobre o citoesqueleto de actina e expressão de integrinas $\alpha$ e $\alpha 2$ em

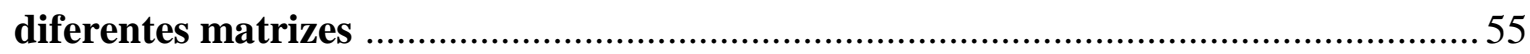

4.6 Efeito da CTX sobre o citoesqueleto de actina e sobre a expressão de integrinas $\alpha \mathrm{v}$ e $\boldsymbol{\alpha 2}$ em diferentes matrizes sob estímulo tumoral ....................................................... 57

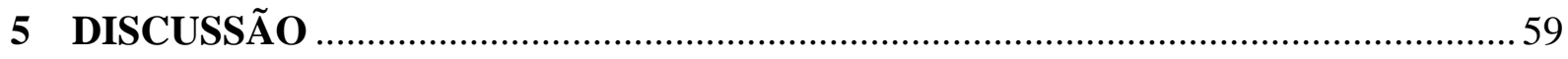

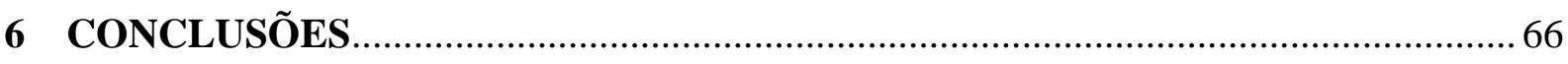

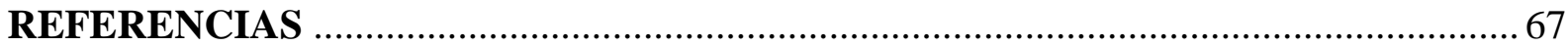




\section{INTRODUÇÃO}

Os venenos animais contêm grande variedade de toxinas, em sua maioria peptídeos e proteínas, que são utilizadas para a captura de presas e como defesa. Ainda, são constituídos por misturas complexas de substâncias inorgânicas e orgânicas. Os constituintes inorgânicos incluem cálcio, cobre, ferro, potássio, magnésio, manganês, sódio, fósforo, cobre e zinco (FRIEDERICH; TU, 1971). Os componentes orgânicos são representados principalmente por proteínas com propriedades enzimáticas, peptídeos biologicamente ativos e algumas moléculas não-protéicas, que agem isolada ou sinergisticamente, interferindo em mecanismos fisiológicos, celulares e moleculares específicos (LEE, 1979). Alguns destes componentes do veneno possuem efeitos tóxicos, sendo assim denominados toxinas, e estas são responsáveis por diversos efeitos biológicos, como distúrbios na coagulação sanguínea, hemólise, hemorragia local e sistêmica, hipotensão, efeitos neurotóxicos, necrose tecidual, entre outros (IWANAGA; SUZUKI, 1979; MARKLAND, 1998; TANEN et al., 2001; WALTER; BIDLEN; GIBLY,1999).

Apesar da sua toxicidade, vários trabalhos da literatura têm demonstrado a importância de compostos derivados de venenos de serpentes para o tratamento de diferentes patologias. Isto se deve ao fato de milhões de anos de evolução terem conferido a estas substâncias, duas características importantes para o desenvolvimento de um fármaco: especificidade e seletividade a seus alvos (celulares e moleculares, como canais iônicos, receptores, enzimas, membranas celulares ou vias metabólicas) (BAILEY; WILCE, 2001; CURY; PICOLO, 2006; LEWIS; GARCIA, 2003).

Desta forma, as toxinas animais se constituem em importante ferramenta para o estudo das propriedades fisiológicas e farmacológicas destes alvos e para a compreensão de como disfunções destes alvos podem contribuir para o desenvolvimento de diversas doenças. Adicionalmente, estas toxinas, em decorrência de sua seletividade ou mesmo especificidade pelos seus alvos, são modelos importantes para o desenho de novos e eficazes agentes terapêuticos.

\subsection{Veneno de serpentes Crotalus durissus terrificus (VCdt) e suas toxinas isoladas}

O gênero Crotalus inclui as serpentes popularmente conhecidas como cascavéis, causadoras de aproximadamente 7,6\% dos acidentes ofídicos no Brasil (SINAN, 2011), sendo estes acidentes causados principalmente pela Crotalus durissus terrificus. 
As manifestações clínicas do envenenamento por serpentes Crotalus durissus terrificus são decorrentes particularmente, da atividade neurotóxica do veneno e são caracterizadas pelo aparecimento do chamado "facies miastênico" ou "facies neurotóxico", onde se observam ptose palpebral, diplopia, flacidez da musculatura facial e paralisia dos nervos cranianos (ROSENFELD, 1971). Além disso, em decorrência desta atividade neurotóxica é observada também insuficiência respiratória (AMARAL; MAGALHÃES; DE REZENDE, 1991; ROSENFELD, 1971). Além desta atividade, o veneno destas serpentes possui atividades miotóxica e coagulante (AZEVEDO-MARQUES et al., 1985; CUPO; AZEVEDO-MARQUES; HERING，1988; NAHAS; MACFARLANE; DENSON, 1964; ROSENFELD, 1971;), induzindo o quadro de rabdomiólise generalizada e incoagulabilidade (AZEVEDO-MARQUES; CUPO; HERING, 1987; SANO-MARTINS et al., 2001).

Apesar destes efeitos sistêmicos importantes, não são observados, nestes envenenamentos, sinais inflamatórios significativos no local da picada (AMORIM; DE MELLO; SALIBA, 1951; BRAZIL, 1950). São relatadas ainda, ausência de dor ou dor de pequena intensidade, seguida de parestesia local (ROSENFELD, 1971). Vale ressaltar que, além de não causar dor, Brazil (1950) evidenciou que este veneno é capaz de causar analgesia em humanos, sendo utilizado no início do século passado, no tratamento de algias, principalmente de origem neoplásica.

As principais toxinas presentes neste veneno incluem a crotoxina, crotamina, convulxina e giroxina. Tem sido sugerido que a giroxina e a enzima tipo trombina sejam o mesmo componente, uma vez que ambas apresentam as mesmas características bioquímicas e biológicas (ALEXANDER et al., 1988). A elevada toxicidade do veneno é atribuída à crotoxina, seu principal componente tóxico, (VITAL-BRAZIL, 1972), que corresponde à 60\% do veneno total (SLOTTA; FRAENKEL-CONRAT, 1938), contribuindo com cerca de $80 \%$ da letalidade induzida pelo veneno total.

\subsubsection{Crotoxina}

A crotoxina (CTX) foi isolada por Slotta e Fraenkel-Conrat (1938), e teve sua estrutura descrita por Fraenkel-Conrat e Singer (1956), sendo uma $\beta$-neurotoxina heterodimérica, formada pela associação não-covalente de duas diferentes subunidades: a crotapotina (CA) e a fosfolipase $\mathrm{A}_{2}\left(\mathrm{FLA}_{2}-\mathrm{CB}\right)$. Seu peso molecular é de 24 a $26 \mathrm{kDa}$, ponto isoelétrico de 4,7 e exibe atividades fosfolipásica, neurotóxica (bloqueio da transmissão 
neuromuscular) e miotóxica (GOPALAKRISHNAKONE et al, 1984; STOKER, 1990; VITAL-BRAZIL, 1972) (Figura 1).

Figura 1. Estrutura Tetramérica da Crotoxina isolada do veneno de Crotalus durissus terrificus

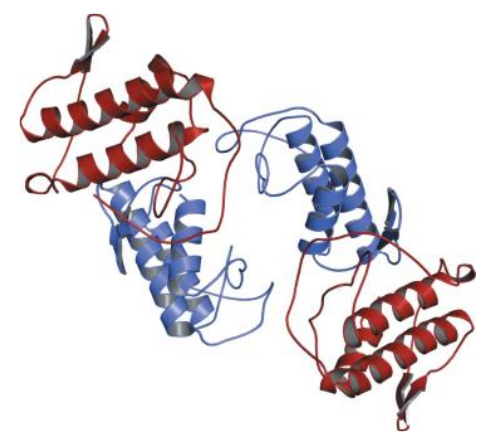

Os monômeros das isoformas CB1 e CB2 estão demonstrados em vermelho e azul, respectivamente. Esta figura foi gerada utilizando PyMOL (DeLano, 2002).

A subunidade CB ou $\mathrm{FLA}_{2}$ apresenta cerca de $14 \mathrm{kDa}$, ponto isoelétrico 9,7, sendo constituída por uma cadeia única polipeptídica contendo 123 resíduos de aminoácidos, formando estruturas globulares associadas por sete pontes dissulfídicas (AIRD et al., 1986). Para a subunidade CB são atribuídas as atividades fosfolipásicas encontradas no veneno crotálico ou na fração CTX. Quando associada à CA, esta FLA 2 apresenta atividade hidrolítica reduzida, porém as atividades neurotóxicas e miotóxicas são potencializadas (CHOUMET et al., 1996).

A CTX exerce seu efeito por meio da associação da fração FLA $_{2}$ aos seus alvos nas membranas, levando à dissociação do complexo, onde CA permanece em solução, enquanto CB interage com seus aceptores. Foram realizados estudos no intuito de compreender a ligação da CTX às membranas pré-sinápticas, e esclarecer a participação da subunidade CA. Délot e Bon (1993) observaram que CA participa temporariamente da etapa na qual CB se associa com seu aceptor na membrana, formando um complexo ternário transitório. A subunidade CA só se dissocia de CB após o acoplamento irreversível deste componente ao aceptor na membrana das terminações nervosas.

A subunidade CA (crotapotina) apresenta peso molecular de $8,9 \mathrm{kDa}$, com ponto isoelétrico de 3,4, características ácidas, sendo desprovida de atividade enzimática e tóxica. Foi demonstrado, por meio de estudos de caracterização e sequenciamento, que esta subunidade é formada por três cadeias polipeptídicas, com 88 aminoácidos, unidas por sete 
pontes dissulfídicas (AIRD et al., 1990). Sua função não está totalmente evidenciada, porém é aceito que CA pode agir como uma molécula carreadora potencializando a atividade letal de CB, porém sua atividade enzimática diminui dentro do complexo CTX (BON et al., 1989; CHOUMET et al., 1996).

\subsection{Estudos experimentais sobre os efeitos imunorregulatório, anti-inflamatório e antitumoral do veneno de Crotalus durissus terrificus (VCdt) e suas toxinas isoladas}

Vários estudos experimentais têm mostrado que, o VCdt ou substâncias isoladas deste veneno são capazes de modular as respostas inflamatória e imune (SAMPAIO et al., 2010). Em relação aos efeitos sobre o sistema imune, foi evidenciado que o veneno crotálico ou a CTX apresentam papel supressor sobre a resposta imunológica humoral (CARDOSO; MOTA, 1997). Ainda, Cardoso et al. (2001) mostraram que a CTX, quando injetada por via subcutânea em camundongos, é capaz de induzir diminuição do número de leucócitos circulantes. Dados obtidos em nosso laboratório são indicativos de que o VCdt, CTX e o componente $\mathrm{CB}\left(\mathrm{FLA}_{2}\right)$, mas não a crotapotina, administrados por via subcutânea, em ratos, reduzem o número de linfócitos circulantes em ratos. Este efeito é modulado, pelo menos em parte, por mediadores gerados na via da 5-lipoxigenase (ZAMBELLI et al., 2008).

Em relação à resposta inflamatória, Landucci et al. (1995, 2000) mostraram que a crotapotina inibe o edema de pata de ratos induzido por carragenina ou por fosfolipases $\mathrm{A}_{2}$ isoladas de venenos animais. Ainda, a injeção, em camundongos, de VCdt, imediatamente após a administração intraperitoneal de tioglicolato, determina decréscimo no número de leucócitos que migram para a cavidade peritoneal (SOUSA-E-SILVA; GONÇALVES; MARIANO, 1996). Em continuidade a esses estudos, Nunes et al. (2007) mostraram que a ação inibitória sobre os componentes vascular e celular da resposta inflamatória, induzida pela carragenina, é de longa duração e mais efetiva quando comparado a anti-inflamatórios clássicos, caracterizando assim, o efeito anti-inflamatório sugerido para este veneno. Esses mesmos autores demonstraram que a CTX é a toxina responsável por este efeito prolongado (NUNES et al., 2010).

Sampaio et al. (2001), avaliando o efeito do veneno de cascavel sobre o metabolismo de macrófagos e a possível correlação entre as modificações deste metabolismo e as alterações funcionais destas células, demonstraram dualismo na ação deste veneno, uma vez que foi observada tanto inibição de alguns parâmetros funcionais, como espraiamento e fagocitose, quanto estimulação do "burst" respiratório (geração de peróxido de oxigênio), da 
geração de óxido nítrico, da atividade microbicida (fungicida) e do metabolismo de glicose e glutamina destas células. O incremento deste metabolismo foi demonstrado através da determinação da influência do veneno sobre a atividade máxima de enzimas-chave do metabolismo de glicose e glutamina (hexoquinase, glicose-6-fosfato desidrogenase, citrato sintase e glutaminase dependente de fosfato) e da oxidação destes substratos. Tanto as ações estimulatórias quanto inibitórias são de longa duração, pois serão observadas por até 7 dias após a administração de uma única dose do veneno. Estes efeitos manifestam-se independentemente do estado de ativação do macrófago - residente, inflamatório ou ativado. Contudo, as ações estimulatórias do VCdt são mais significativas no macrófago residente. Os mesmos autores demonstraram que a CTX e a subunidade $\mathrm{FLA}_{2}$, mas não as outras toxinas presentes no veneno, inibem as funções de espraiamento, mantendo a forma arredondada, não apresentando as mesmas alterações de prolongamento de membrana características de células espraiadas e fagocitose por macrófagos, de maneira similar ao observado para o veneno total, sendo considerada o fator responsável por estes efeitos do veneno sobre fagócitos (SAMPAIO et al., 2003; SAMPAIO et al., 2005; SAMPAIO et al., 2006a).

Recentemente, nosso grupo demonstrou, que a CTX é a toxina responsável pela ação estimulatória sobre o "burst" respiratório de macrófagos residentes obtidos da cavidade peritoneal de ratos normais, sendo este efeito prolongado, pois é observado após 14 dias da administração de uma única dose de CTX (COSTA et al., 2010). Este estudo evidenciou que a CTX é a responsável pelo efeito dual demonstrado para o veneno total.

Em relação à sinalização intracelular, tanto o veneno, quanto CTX inibem drasticamente a fosforilação de tirosina-quinase e a expressão das proteínas GTPases RhoA e Rac, interferindo assim, com a eficiência do citoesqueleto na captação das partículas a serem fagocitadas (SAMPAIO et al., 2006b). Estes efeitos são modulados, pelo menos em parte, por mediadores gerados na via da lipoxigenase (SAMPAIO et al., 2006a). Ainda, foi demonstrado que tanto o veneno crotálico como as toxinas isoladas são capazes de aumentar a liberação da lipoxina $\mathrm{A}_{4}$ (SAMPAIO et al., 2006a), um mediador lipídico gerado na via das lipoxigenases com potente efeito anti-inflamatório (MCMAHON; GODSON, 2004) e inibidor de diversos eventos envolvidos com o crescimento tumoral (CEZAR-DE-MELLO et al., 2008; FIERRO, 2005).

Em estudos realizados em nosso laboratório, foi demonstrada a ação antitumoral da CTX in vivo, no modelo experimental de tumor desenvolvido no coxim plantar de pata de ratos, induzido pela injeção do tumor de Walker 256. Estudos realizados pelo nosso grupo mostraram que células de tumor de Walker 256, injetadas por via intraplantar, são capazes de 
causar desenvolvimento de tumor sólido no coxim plantar de ratos a partir do $3^{\circ}$ dia de inoculação. A presença marcante de células tumorais na pata dos ratos foi evidenciada, por análises histopatológicas, no $5^{\circ}$ dia do desenvolvimento do tumor (BRIGATTE et al., no prelo). Animais tratados pela CTX apresentaram menor aumento do volume da pata causado pelo tumor, evidenciado por meio de pletismografia, quando comparado aos animais controles. Neste estudo, análises histológicas do coxim plantar sugerem que a CTX interfere com a neovascularização na vigência do tumor. Cabe ressaltar que, neste mesmo estudo, foi demonstrado que a CTX foi capaz também de inibir fenômenos nociceptivos, tais como, hiperalgesia, alodinia e dor espontânea, causados pelo câncer, observado no modelo de pressão de pata de ratos. Em continuidade a esses estudos, ensaios in vitro evidenciaram ação antitumoral da CTX, uma vez que a toxina inibiu a proliferação das células da linhagem LLC WRC 256, correspondente ao tumor de Walker 256 (FAIAD; DELLA-CASA; SAMPAIO,2008). Neste estudo, foi demonstrado que esta toxina interfere com os eventos fundamentais da progressão tumoral, agindo diretamente sobre as células tumorais desta linhagem, inibindo a proliferação, adesão da célula tumoral à fibronectina, além de inibir a polimerização dos filamentos de actina dessas células. Ainda, as proteínas sinalizadoras da família das GTPases Rho, tais como a RhoA e a quinase FAK apresentam a atividade diminuída após a incubação na presença da toxina, o que explica, pelo menos em parte, a diminuição da projeção do corpo celular durante a proliferação, conforme observado em ensaios de Microscopia Confocal (FAIAD; DELLA-CASA; SAMPAIO, 2008).

Apesar das evidências da ação antitumoral da CTX, e de que esta toxina acarreta inibição tanto na fosforilação de tirosina quinase quanto na expressão das proteínas Rho GTPases, efeito mediado por derivados da via 5-lipoxigenase, não foi demostrado, até o momento, a ação desta toxina sobre a angiogênese. Estudos demonstrando a ação da CTX sobre parâmetros fundamentais para a neovascularização pode contribuir para novas perspectivas no desenvolvimento de uma nova substância com propriedades terapêuticas no controle de neoplasias.

\subsection{Progressão Tumoral e Angiogênese}

Angiogênese é definida como a formação de novos vasos sanguíneos a partir de vasos pré-existentes, sendo componente fundamental durante processos fisiológicos, tais como o desenvolvimento vascular embrionário, e em adultos, para o ciclo ovariano e reparo de feridas. Além dos processos fisiológicos, a angiogênese também é essencial para a progressão 
de diversas desordens que dependam diretamente da neovascularização, tais como retinopatias diabéticas, artrite reumatóide e crescimento tumoral (FOLKMAN, 1995).

Em relação ao desenvolvimento tumoral, que envolve o crescimento do tumor e, consequentemente, invasão aos tecidos mais distantes, a angiogênese é um dos fatores essenciais por promover a progressão tumoral devido ao fornecimento de nutrientes, oxigênio e fatores de crescimento necessários para a sobrevida da célula tumoral. Este processo envolve diretamente uma interação entre as proteínas da matriz extracelular e as células endoteliais vasculares, as quais respondem a diversos fatores pró-angiogênicos e antiangiogênicos secretados pelo microambiente tumoral (BAZAA et al., 2010; ELICEIRI; CHERESH, 1998; MONTAÑEZ et al., 2002).

Inicialmente, o tumor cresce em área avascular, sob condições de hipóxia e privação de nutrientes permitindo um equilibrio entre os fatores pró-angiogênicos, como o fator de crescimento vascular endotelial (VEGF), fator de crescimento do fibroblasto tipo 2 (FGF-2), fator de crescimento derivado da plaqueta (PDGF), fator de crescimento transformante $\beta$ (TGF- $\beta$ ), citocinas pró-inflamatórias como fator de necrose tumoral $\alpha$ (TNF- $\alpha$ ) e os fatores antiangiogênicos como interferons, endostatina, angiostatina, trombospotina e inibidores das metaloproteinases (DASS; TRAN; CHOONG, 2007; MELO; JUNQUEIRA, CHAMMAS, 2003).

Porém, conforme o crescimento da massa tumoral, ao ultrapassar alguns milimetros de diâmetro (cerca de 1 a $2 \mathrm{~mm}$ ), aumenta a sua necessidade por nutrientes e fornecimento de oxigênio a partir do sangue, e consequentemente há o aumento da expressão de fatores próangiogênicos como as citocinas e fatores de crescimento (MELO; JUNQUEIRA, CHAMMAS, 2003; WEIS; CHERESH, 2011). Neste sentido, o VEGF, por exemplo, é regulado pela hipóxia levando a célula tumoral a secretar este fator e, assim, promover a proliferação e migração de células endoteliais vasculares, por meio da interação entre o VEGF e seu receptor tirosina quinase (VEGFR) localizado na superfície destas células, formando brotos a partir dos vasos pré-existentes. Esses brotamentos crescem e invadem a matriz extracelular, por meio da secreção de proteinases, em direção à célula tumoral. Os vasos passam a se organizarem em redes do tipo capilares adquirindo características estruturais e funcionais (CUENOD et al., 2006). No tumor, as células endoteliais vasculares (CEVs) proliferam de 50 a 100 vezes mais rápidas do que as células normais, sendo uma CEV capaz de manter mais de cem células tumorais (DASS; TRAN; CHOONG, 2007). Portanto, a formação de novos capilares por estruturas vasculares pré-existentes é de importância fundamental durante o processo de angiogênese (FOLKMAN, 2007). 


\subsubsection{Interação entre célula endotelial e matriz extracelular (MEC) na angiogênese}

As células endoteliais são originadas a partir da medula óssea onde ocorre uma diferenciação sucessiva de células mesodérmicas em hemangioblastos. Os hemangioblastos darão origem às células tronco hematopoiéticas que se diferenciarão em células do sangue, e em células tronco vasculares que originarão células precursoras endoteliais (CPE) e os perócitos (LACAUD; KELLER; KOUSKOFF, 2004; LAMALICE; LE BOEUF; HOUT 2007).

As células endoteliais vasculares são provenientes da diferenciação das CPEs apresentando forma alongada com núcleo proeminente, prolongamentos citoplasmáticos sendo repleto de organelas intracelulares. Por conta de sua estrutura, esta célula possui intensa atividade metabólica, devido a presença de cavéolas que são invaginações na membrana citoplasmática conferindo a capacidade da célula endotelial de reconhecer fatores e hormônios na superfície da célula por meio de receptores, moléculas sinalizadoras e efetoras e várias substâncias que estimulam a célula endotelial a exercer suas funções (MICHEL, 1998). Dentre esses receptores,são descritas as moléculas de adesão do tipo integrina (ICAM-1, VCAM-1 E PECAM) e selectinas (selectina P e selectina E), bem como receptores para proteínas de matriz extracelular, como fibronectina, laminina, trombospondina, colágenos I, II, III, IV e V, elastina, heparan sulfato, condroitim sulfato, entre outros (JAFFE, 1987). Além disso, a célula endotelial também expressa receptores para quimiocinas (CXCR4, CXCR7) (SALCEDO; OPPENHEIM, 2003; SINGH et al., 2013).

Mudanças na composição de matriz extracelular que circundam as células endoteliais coincidem com o comportamento proliferativo dessas células (FORM; PRATT; MADRI, 1986). Neste contexto, a matriz extracelular possui importância fundamental para a organização e o comportamento da célula endotelial tanto em condições fisiológicas como fisiopatológicas por estarem em constante comunicação, portanto, permitindo que a célula endotelial desempenhe suas funções de adesão, proliferação, migração, diferenciação, transdução de sinal e morfogênese. A matriz extracelular pode ser dividida em duas subcategorias: membrana basal, que está diretamente em contato com o endotélio; e matriz intersticial, que em condições fisiológicas, não está diretamente em contato com as células endoteliais (FRANCIS; URIEL; BREY, 2008). As duas subdivisões diferem quanto à distribuição no tecido e composição química, uma vez que a matriz intersticial consiste em colágeno fibrilar (tipo I), elastina, fibrina e glicoproteínas adesivas como fibronectina, proteoglicanos e ácido hialurônico, ao passo que a membrana basal consiste em laminina, 
colágeno não fibrilar (principalmente o tipo IV), nidogen, heparan sulfato e proteoglicanos como perlecan (FRANCIS; URIEL; BREY, 2008; NISHIUCHI et al., 2006; ROSARIO; DESIMONE, 2010).

Durante a angiogênese, os componentes da membrana basal, tais como colágeno tipo IV, principal componente da membrana que em conjunto com a laminina, a principal proteína adesiva da membrana basal, estabilizam os novos vasos formados. Já, os componentes intersticiais, especialmente o colágeno fibrilar (tipo I), o mais abundante, promovem rápido e invasivo crescimento da célula endotelial. A fibronectina, também uma das principais proteínas da MEC, desempenha importente papel na cascata da angiogênese, regulando a sobrevida, diferenciação e proliferação das células, eventos intensificados dentro e em torno de tumores sólidos. Nos estágios iniciais da angiogênese, a expressão local de proteases rompe a membrana basal, criando uma mudança química e física no microambiente da célula endotelial que inicia a formação de brotos (FRANCIS; URIEL; BREY, 2008). Sendo assim, os fatores angiogênicos, jutamente com os componentes da matriz extracelular, são essenciais para a adesão, proliferação e migração das células endoteliais.

\subsubsection{Adesão, Proliferação e Migração Celular: Principais aspectos.}

Durante o desenvolvimento tumoral, os fatores de crescimento pró-angiogênicos liberados pelas células tumorais ativam as células endoteliais quiescentes que irão degradar a matriz extracelular, estimulando a expressão de receptores de superfície, importantes para a adesão, migração e formação de estruturas tubulares (MELO; JUNQUEIRA, CHAMMAS, 2003).

As integrinas são as primeiras moléculas de superfície de adesão que facilitam comunicação bidirecional entre a célula endotelial e os componentes da matriz extracelular (WEIS; CHERESH, 2011). Por meio dessa interação, a sinalização intracelular é desencadeada, permitindo sua adesão à matriz e, consequentemente, a reorganização do citoesqueleto e a mudanças no comportamento celular como, por exemplo, no estímulo à proliferação celular (SILVA et al., 2007), na migração e invasão celular (WEIS; CHERESH, 2011).

Estruturalmente, as integrinas são proteínas heterodímericas transmembranas com domínio intracelular composta por suas subunidades, $\alpha$ e $\beta$, associadas por ligação nãocovalente (ELICIERI; CHERESH, 1998; NOGUERA et al., 2012). 
A subunidade $\alpha$ é capaz de se ligar especificamente a determinada proteína da matriz enquanto que a subunidade $\beta$ está em contato com a região citoplasmática, capaz de recrutar proteínas acessórias ancoradas aos filamentos de actina e é responsável pela ativação de diferentes vias de sinalização que regulam a organização do citoesqueleto de actina, a geração de força de contração (BARCZYK; CARRACEDO; GULLBERG, 2010; HOOD; CHERESH, 2002; LAMALICE; LE BOEUF; HOUT, 2007).

Existem 18 tipos da subunidade $\alpha$ e 8 tipos da subunidade $\beta$ que podem se associar em 24 integrinas. Cada associação se ligará a um componente específico da matriz extracelular, como colágenos, lamininas, proteínas que contém sequência RGD como a fibronectina, fibrinogênio (AVRAAMIDES; GARMY-SUSINI; VARNER, 2008; BARCZYK; CARRACEDO; GULLBERG, 2010; MARGADANT et al., 2011).

Durante a angiogênese, é observado aumento da expressão das principais integrinas envolvidas nesse processo, contribuindo para a regulação do crescimento, sobrevida e migração das células endoteliais. Há uma variedade de integrinas que são expressas pelas células endoteliais, tais como: $\alpha 2 \beta 1, \alpha 5 \beta 1, \alpha 5 \beta 3, \alpha 6 \beta 4, \alpha v \beta 3$ e $\alpha v \beta 5$ (SCHLIE-WOLTER; NGEZAHAYO; CHICHKOV, 2013). Estas integrinas são fortemente induzidas pelos fatores de crescimento pró-angiogênico ou quimiocinas capazes de alterar a conformação dessa molécula, tornando-a ativa (AVRAAMIDES; GARMY-SUSINI; VARNER, 2008; BAZAA et al., 2010). Algumas destas integrinas são expressas durante condições fisiopatológias, entretanto, a integrina $\alpha v \beta 3$ é considerada um importante alvo farmacológico, uma vez que não é encontrada em células endoteliais quiescentes, porém, na presença de citocinas ou tumores, sua expressão é intensamente estimulada (BAZAA et al., 2010; MELO; JUNQUEIRA, CHAMMAS, 2003; SILVA et al., 2007). Esta integrina, por sua vez, possui capacidade de se ligar a diversos substratos, incluindo a fibronectina, vitronectina, fibrinogênio, fator von Willebrand, osteopontina, trombina (BAZAA et al., 2010; WEIS; CHERESH, 2011) e formas proteolisadas de colágeno e laminina, enquanto que a integrina $\alpha 5 \beta 1$ se liga seletivamente a fibronectina (HOOD; CHERESH, 2002). Alguns estudos indicam que a integrina $\alpha v \beta 3$ está envolvida na adesão ao substrato, migração e formação de estruturas do tipo capilar (AVRAAMIDES; GARMY-SUSINI; VARNER, 2008; NISATO et al., 2003).

Em relação ao colágeno tipo I, principal componente da matriz extracelular, é substrato para as integrinas $\alpha 1 \beta 1, \quad \alpha 2 \beta 1, \quad \alpha 10 \beta 1$ e $\alpha 11 \beta 1$ (SCHLIE-WOLTER; NGEZAHAYO; CHICHKOV, 2013). Em particular, a integrina $\alpha 2 \beta 1$, expressa pelas células endoteliais, é essencial em processos fisiológicos e fisiopatológicos, como cicatrização de 
feridas, metástase de tumor, e trombose, sendo todas dependentes da ligação da integrina ao colágeno (BROOS et al., 2012; ECKES et al., 2006). Ainda, a integrina $\alpha 2 \beta 1$ espressas nas células endoteliais é também receptor para laminina (LANGUINO et al., 1989), sendo importante para a adesão das células, bem como o crescimento, diferenciação e migração (KUBOTA et al., 1988).

Logo após a ligação das integrinas aos seus ligantes na matriz extracelular, ocorre mudança na conformação do citoesqueleto da célula endotelial e, consequentemente, modulação da migração celular devido ao domínio citoplasmático da integrina que está em conexão funcional com as proteínas acessórias ( $\alpha$-actinina, vinculina, tensina e paxilina) associadas ao citoesqueleto de actina, iniciando uma cascata de sinalização angiogênica (HOOD; CHERESH, 2002; LAMALICE; LE BOEUF; HOUT, 2007; PARSONS; HORWITZ; SCHWARTZ, 2010). Entre essas vias de sinalização intracelular, a FAK (proteína quinase de adesão focal) é um mediador da transdução de sinal pelas integrinas e pelos receptores de fatores de crescimento nas células endoteliais co-localizada com a região citoplasmática das integrinas e pode ativar direta e indiretamente moléculas sinalizadoras responsáveis por regular a proliferação e a migração celular (AVRAAMIDES; GARMYSUSINI; VARNER, 2008). Entre essas proteínas sinalizadoras, a via da ERK (extracellularsignal regulated kinase) promove a atividade da quinase de cadeia leve de miosina (MLCK), bem como a atividade transcricional e alteração da afinidade entre a integrina e o ligante (HOOD; CHERESH, 2002) (Figura 2). Ainda, estudos sugerem que as integrinas podem ter uma interação recíproca (crosstalk) com receptores de tirosina quinase como o c-Met, receptor para fator de crescimento hepatócito (HGF), envolvidos com a proliferação, migração e morfogênese celular por meio da ativação da via da ERK (CHAN et al., 2006). Portanto, durante a angiogênese a formação da adesão, sua maturação e reorganização do citoesqueleto é um processo contínuo e balanceado entre a polimerização da actina e a contração da actomiosina (PARSONS; HORWITZ; SCHWARTZ, 2010), essencial para a migração celular.

A migração celular, por sua vez, não é um processo exclusivo da angiogênese, é importante para o desenvolvimento, como também em eventos como reparo tecidual e sobrevivência imunológica (LAMMERMANN et al., 2008). A aderência das células endoteliais à matriz extracelular durante a migração é um evento que ocorre dependente ou independemente de quimioatrativos. Neste sentido, os componentes da MEC como colágeno tipo I e fibronectina são, por si só, capazes de sustentar, guiar e regular a velocidade da migração (LAMALICE; LE BOEUF; HOUT, 2007). A migração da maioria das células 
consiste em quatro eventos seqüenciais básicos, que ocorrem de maneira cíclica: (1) protrusão da parte dianteira da célula, (2) adesão à matriz extracelular, (3) deslocamento do corpo celular, e (4) retração da parte traseira (RIDLEY et al., 2003).

\section{Figura 2. Principais aspectos da sinalização intracelular mediada pelas integrinas}

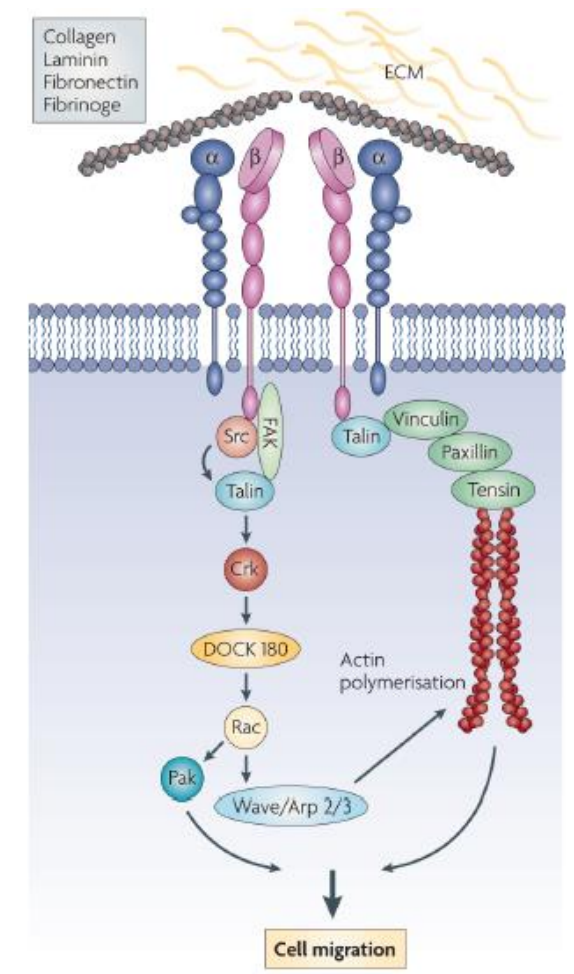

As integrinas medeiam a ligação entre a célula endotelial aos diferentes componentes de matriz extracelular e disparam sinalização intracelular envolvendo proteínas quinases, tais como quinases de adesão focal (FAK), sinalização intermediária, tais como fosfatidilinosital 3-quinase, as proteínas da família das Rho GTPAses e proteínas do citoesqueleto ligantes de actina, tais como a paxilina, $\alpha$-actinina e vinculina, promovendo o remodelamento do citoesqueleto de actina para a adesão, migraçãoe proliferação celular. Esta figura foi obtida de Avraamides; Garmy-Susini; Varner, 2008 in Nature Reviews/Cancer.

Ainda, no que concerne à sinalização envolvida com a migração celular, o citoesqueleto de actina é constantemente remodulado e regulado pelas proteínas Rho GTPases que ciclam entre um estado inativo (ligadas a GDP) e um estado ativo (ligadas a GTP). Uma vez ativadas, as Rho GTPases ligam-se a diferentes proteínas efetoras, por exemplo ROCK, desencadeando uma cascata de sinalização envolvidas em vários processos celulares, incluindo adesão, polaridade celular, expressão gênica, proliferação, apoptose e atividade de fator de transcrição (BRYAN; D’AMORE, 2007; VEGA; RIDLEY, 2008). Ainda, essas proteínas estão envolvidas no controle da morfologia e motilidade celular por meio da 
organização do citoesqueleto de actina de células não transformadas (SAHAI; MARSHALL, 2002).

As Rho GTPases são uma família de proteínas que possuem mais de 18 membros identificados e são subdivididas de acordo com sua sequencia e função (SAHAI; MARSHALL, 2002), porém as proteínas melhor caracterizadas e mais amplamente distribuídas são RhoA, Rac1 e Cdc42 que regulam as etapas envolvidas com a migração celular (NOBES; HALL, 1999; SANDER; COLLARD, 1999). A proteína Rac1 está principalmente envolvida na formação de lamelipódios enquanto que a Cdc42, está envolvida na formação de filopódios que direcionam o movimento da célula, essas protrusões formam adesões imaturas junto ao substrato de matriz extracelular, denominadas adesões nascentes e a medida em que a célula se projeta em direção ao sítio de migração, algumas dessas adesões se desfazem enquanto outras amadurecem, essas tornam-se complexos focais e posteriormente adesões focais. Essa maturação de adesões gera contractilidade da célula por meio do ancoramento dos feixes de filamentos de actina e miosina II (stress fibers) que são reguladas pela Rho (isoformas A, B ou C) (RIDLEY; HALL, 1992; RIDLEY et al., 1992; SAHAI; MARSHALL, 2002). O balanço recíproco entre Rac1 e RhoA determina a morfologia celular e o comportamento migratório (HERBRAND; AHMADIAN, 2006). Após o amadurecimento das adesões junto ao substrato a célula desloca seu corpo para a frente e a parte traseira é tracionada pelas stress fibers. O ciclo termina com a liberação das adesões que foram utilizadas na parte traseira da célula, podendo estas entrar em uso novamente (LAMALICE; LE BOEUF; HOUT, 2007; RIENTO; RIDLEY, 2003). Ainda, as Rho GTPases podem também regular a produção de metaloproteinases (MMPs) afetando o remodelamento da matriz extracelular,que circunda vasos sanguíneos favorecendo a migração das células endoteliais a partir da membrana basal para formar uma nova via de migração e, contribuindo assim, para a invasão das células endoteliais e, consequentemente, progressão tumoral (VEGA; RIDLEY, 2008).

A degradação da matriz depende da expressão e ativação da metaloproteinases, uma família de enzimas zinco-dependente. Para a invasão, estruturas superficiais encontradas em células especializadas (células tumorais e estromais), denominadas invadopodia utilizam MMPs,ativadas e secretadas no local, tais como MMP-2 e -9 para degradar diversas macromoléculas da MEC e facilitar a invasão celular (CEZAR-DE-MELLO et al., 2008). Entre esses membros da família das MMPs, a MMP-9 participa do switch angiogênico, uma vez que controla a liberação de VEGF, enquanto que a MMP-2 contribui para o crescimento tumoral (BERGERS et al., 2000; GIALELI; THEOCHARIS; KARAMANO, 2011). 
Como citado anteriormente, as CEVs proliferam de 50 a 100 vezes mais rápidas do que as células normais e expressam marcadores específicos que podem ser alvos de agentes terapêuticos. Ainda, uma CEV é capaz de manter mais de cem células tumorais, sugerindo, portanto, que a destruição de um único vaso sanguíneo pode erradicar um número considerável de células tumorais (DASS; TRAN; CHOONG, 2007). Estes fatos tornam relevantes estudos de substâncias com potencial anti-angiogênico.

\section{$1.4 \quad$ Modelos experimentais in vitro}

Nos ensaios experimentais, utilizando os modelos in vitro é essencial mimetizar as condições naturais possíveis envolvidas no ambiente celular. Neste sentido, ao escolher um modelo para a realização de experimentos in vitro são imprescindíveis os cuidados com a observação, mensuração e a manipulação das células para que o sistema in vitro reproduza o comportamento celular observado no ambiente in situ. Os estudos de migração celular e invasão estão sendo amplamente realizados em modelos de MEC de colágeno (WOLF et al., 2009). No colágeno se obtém uma estrutura de substrato fibrilar que favorece a adesão, bem como apresenta-se como barreira para a movimentação celular, similar aos tecidos intersticial rico em colágeno obtidos in vivo. Portanto, estes modelos são adequados para examinar aspectos distintos do movimento celular em um ambiente similar ao tecido, considerando sua geometria e fonte, e variação em suas propriedades estruturais básicas. Os monômeros de colágenos podem ser obtidos de diferentes espécies, tais como roedores e bovinos. Neste sentido, pesquisas recentes sobre o comportamento celular analisado em matriz de colágeno extraído de cauda de rato (EHRMANN; GEY, 1956; ELSDALE, 1972) reconstituído tridimensionalmente (ALEXANDER et al, 2008; NTAYI et al., 2001; WOLF et al., 2003; WOLF et al., 2009).

O estudo com células endoteliais pode ser feito por meio do cultivo das células em monocamada utilizando-se células endoteliais originárias de diversos tecidos, como veia de cordão umbilical humano (HUVEC), aorta bovina e veia safena humana (MORGAN, 1998). Também, podem ser utilizadas linhagens celulares que possuem maior capacidade de proliferação e mantidas com um fenótipo próximo ao das células originais por um número maior de passagens, o que viabiliza a realização de vários experimentos. Segundo trabalho desenvolvido por Ramos (2008), o hormônio do crescimento modula, in vitro, algumas funções da linhagem de células endoteliais tímica t.End.1, incluindo proliferação, morfologia, expressão de receptores de matriz extracelular, produção de matriz extracelular, adesão de 
timócitos às células endoteliais, assim como migração transendotelial de timócitos (PARK et al., 2001), demonstrando que estas células reproduzem um bom modelo para estudos dos aspectos funcionais fundamentais envolvidos na angiogênese.

\subsubsection{Sistemas bidimensionais (2D) e tridimensionais (3D)}

Conforme citado anteriormente, a adesão celular a matriz extracelular é uma etapa essencial para angiogênese e, ao longo de três décadas, diversos estudos em superfícies bidimensionais (2D) contribuiram para a compreensão de moléculas de sinalização necessárias para este processo. Nestas superfícies, também foram estudados mecanismos de regulação da migração celular, onde uma migração eficiente envolve o início da formação de protrusão na parte dianteira do corpo celular seguido de formação de novos sítios de adesões para estabilizar a protrusão (JAYO; PARSONS, 2012; RIDLEY et al., 2003).

Para estudar a dinâmica das integrinas na interação célula-substrato, transdução de sinais, protrusão de membrana e organização do citoesqueleto, o modelo bidimensional possui essa vantagem, sendo o modelo mais utilizado para avaliar esses parâmetros (EVEN-RAM; YAMADA, 2005; MARTINS; KOLEGA, 2006). No entanto, no substrato 2D, as células possuem migração atípica, semelhante a migração de ameba e leucócitos, envolvendo adaptação conformacional e não adesiva para a matriz. Apresentando comportamento que são diferentes do encontrado nas células in vivo (MARTINS; KOLEGA, 2006).

Portanto, para biomimetizar a migração celular encontrada no in vivo, onde as células estão completamente circundadas pela matriz extracelular, o modelo tridimensional (3D) é o que representa melhor,embora ainda de forma bastante incompleta, o microambiente tecidual (JAYO; PARSONS, 2012).

Células mesenquimais, como fibroblastos e células endoteliais, apresentam migração com forte força de tração entra a célula e matriz tridimensional por meio da ligação da integrina e contractilidade do citoesqueleto (MARTINS; KOLEGA, 2006). Nesse modelo, as células adquirem tensão doral e ventral apresentando, portanto, corpo celular mais alongado, enquanto que no modelo 2D adquirem tensão somente dorsal adquirindo morfologia mais achatada. Apesar das diferenças morfológicas, as células em matriz 3D utilizam a mesma estratégia migratória como as células em 2D (MARTINS; KOLEGA, 2006). Além disso, células em matriz bidimensional apresentam direção da migração randômica, ou seja, as células alternam espontaneamente sua direção de migração por conta da elevada atividade de 
Rac1, enquanto que células em 3D podem ser mais persistentes em direção e apresentam menor atividade de Rac1 (CZUCHRA et al., 2005).

Interações celulares com a matriz extracelular envolvem propriedades químicas, mecânicas e físicas da matriz, além de estruturas celulares como stress fibers e adesão focal, favorecendo o remodelamento da matriz para migração celular por meio da sinalização da integrina, ou seja, as integrinas geram sinalização diferenciada em resposta a superfície 2D rígida e simples, ou a uma matriz 3D maleável e complexa (CUKIERMAN; PANKOV; YAMADA, 2002).

Esses modelos in vitro são também utilizados para estudar os principais mecanismos envolvidos na neovascularização, onde é possível observar a formação de uma rede de estruturas tubulares biomimetizando o in vivo. Montañez et al. (2002) comparou a angiogenese em modelo tridimensional de gel de colágeno tipo I e em modelo bidimensional em coating de Matrigel, contendo predominantemente laminina, colágeno IV e nidogen, mimetizando a membrana basal (FRIELD; BROCKER, 2000); indicando que características in vivo das estruturas do tipo capilar foi melhor reproduzida no modelo de colágeno (MONTAÑEZ et al., 2002).

Outra vantagem de estudar em matriz tridimensional é avaliar também a secreção de metaloproteinases, proteínas que degradam a mambrana, importantes para a invasão das células endoteliais à matriz e consequentemente promover a migração celular e formação de estruturas tipo capilares. A metaloproteinase MTI-MMP (MMP-14) é necessária para ativação da GTPase Cdc42 na matriz tridimensional não sendo necessária para migração celular em substrato 2D (SACHARIDOU et al., 2010). Além da Cdc42, a Rac1 também é necessária para a formação de estruturas tipo capilar em matriz 3D (BAYLESS; DAVIS, 2002). 
Como citado anteriormente, apesar das evidências da ação antitumoral da CTX, não foi caracterizada, até o momento, a ação desta toxina sobre a angiogênese, processo de formação de novos vasos essenciais para o crescimento e sobrevivência do tumor. Assim, estudos demonstrando a ação desta toxina sobre os eventos fundamentais para a neovascularização podem contribuir para novas perspectivas no desenvolvimento de um novo desenho de substâncias com propriedades terapêuticas no controle de neoplasias, além de contribuir para a elucidação dos mecanismos envolvidos com as ações da CTX. 


\section{OBJETIVO}

Esse estudo tem como objetivo avaliar in vitro os efeitos da CTX sobre a adesão, proliferação e migração de células da linhagem endotelial tímica (t.End.1) sobre eventos cruciais da angiogênese.

Para tanto, será avaliada a ação da CTX sobre:

1) a proliferação da célula t.End.1, avaliada por contagem total do número de células;

2) o comportamento de adesão da célula endotelial aos seus ligantes naturais, tais como colágeno tipo I, fibronectina e laminina;

3) a migração da célula endotelial avaliada pelos ensaios de Wound healing e Câmara de transwell;

4) a formação de vasos induzidos em matrigel no modelo 3D;

5) a distribuição de subunidades de integrinas $\alpha 2$ e $\alpha v$ das células t.End.1, bem como a organização do citoesqueleto de F-actina, analisadas em ensaios de imunocitoquímica

Esses ensaios foram realizados após diferentes tempos de incubação em meio de cultura RPMI 1640 ou em meio condicionado obtido de cultura de células tumorais da linhagem MCF-7. 


\section{METODOLOGIA}

\subsection{Obtenção da Crotoxina}

Foi purificada a partir de veneno da espécie Crotalus durissus terrificus, liofilizado, extraído de vários exemplares de espécimes adultos, fornecido pelo Laboratório de Herpetologia do Instituto Butantan e estocado a $-20{ }^{\circ} \mathrm{C}$. A purificação da fração CTX do veneno foi realizada segundo o método descrito por Rangel-Santos et al. (2004), pelo Prof. André Fonseca Alves, assistente técnico responsável do Laboratório de Fisiopatologia do Instituto Butantan.

\subsection{Obtenção do colágeno tipo I a partir da cauda de rato}

Para obtenção do colágeno tipo I, as caudas de ratos Wistar machos, pesando entre 180-200 g foram coletadas imediatamente após a eutanásia e assepsia feita em etanol a 70\%, por 20 min e lavadas em água destilada estéril. É importante salientar que as caudas foram obtidas de animais doados após a obtenção de células peritoneais e pertencentes aos Protocolos de Comissão de Ética números: 832/11 e 1013/13. Os tendões das caudas foram obtidos e picotados com auxílio de pinça e tesoura e, em seguida, foram colocados em placas de petri estéreis até o final da coleta e então transferidos para o erlemmeyer para a adição do ácido acético $0,1 \%$ (40 mL por cauda). O colágeno foi extraído após a incubação overnight, em temperatura ambiente, e por outros 2-3 dias a $4{ }^{\circ} \mathrm{C}$ e agitado esporadicamente. $\mathrm{O}$ volume extraído (por volta de 50-150 mL por cauda) foi transferido para tubo de $50 \mathrm{~mL}$ estéril e centrifugado a $4000 \mathrm{rpm}$, por 2 horas, a $4{ }^{\circ} \mathrm{C}$ para a remoção de material insolúvel. O sobrenadante foi cuidadosamente coletado. Uma alíquota do sobrenadante foi obtida para a determinação da proteína total e do colágeno total, pelo método do Ácido Bicinconínico (BCA) conforme descrito por Wiechelman, Braun e Fitzpatrick (1988). O sobrenadante foi liofilizado e armazenado a $20{ }^{\circ} \mathrm{C}$.

\subsection{Linhagens de células}

a) Para realização desses estudos, foi utilizada a linhagem de células endoteliais tímicas (t.End.1), derivada de endotelioma de timo de camundongo C57BL/6. Essas células foram estabelecidas como endotelial por Williams, Courtneidge e Wagner (1988), utilizadas 
como modelo experimental in vitro (BORASCHI et al.,1991; MENDES-DA-CRUZ et al., 2008; RAMOS, 2008). Amostras destas células estão mantidas em nitrogênio líquido. Estas células foram fornecidas pela Dra. Ana Maria Moura, do Laboratório de Imunopatologia do Instituto Butantan.

b) Para os ensaios de migração, foram utilizados os sobrenadantes das culturas das células tumorais da linhagem MCF-7 (HTB22 - adenocarcinoma mamário humano) (ATCC, Manassas, VA, USA), fornecidos pela Dra. Vanessa Moraes Freitas do Departamento de Biologia Celular e do Desenvolvimento do Instituto de Ciências Biomédicas da Universidade de São Paulo (ICB-USP).

\subsection{Manutenção da cultura celular}

\subsubsection{Células endoteliais da linhagem t.End.1}

Foram descongeladas e restabelecidas às condições de cultura, em garrafas de $75 \mathrm{~cm}^{2}$ próprias para cultivo, com meio de cultura RPMI 1640 (Gibco, Grand Island, NY, EUA) contendo soro bovino fetal (SBF) a 10\% e L-glutamina a 1\%, e acondicionadas em estufa a 37 ${ }^{\circ} \mathrm{C}$ e $5 \%$ de $\mathrm{CO}_{2}$ por 48 horas. Após encontrar-se em estado de semiconfluência (80\%), foram submetidas ao tratamento com tripsina/EDTA (Invitrogen), para posteriormente serem utilizadas de acordo com o protocolo experimental desejado.

\subsubsection{Células tumorais da linhagem MCF-7}

As células de tumor mamário humano foram descongeladas e restabelecidas à condição de cultura, em garrafas de $75 \mathrm{~cm}^{2}$ próprias para cultivo, com meio de cultura DMEM (Dulbecco's Modified Eagle Medium, Sigma-Aldrich, Canadá) contendo SBF a 10\%, glicose a $0,45 \%$ e L-glutamina a $1 \%$, e acondicionadas em estufa a $37{ }^{\circ} \mathrm{C}$ e $5 \%$ de $\mathrm{CO}_{2}$ por 72 horas. Após encontrar-se em estado de semiconfluência (90\%), foram submetidas ao tratamento com tripsina/EDTA, para posteriormente serem utilizadas de acordo com o protocolo experimental desejado.

\subsection{Ensaio de proliferação}


Para avaliar o efeito da toxina sobre a proliferação das células t.End.1 $\left(5,0 \times 10^{4} / \mathrm{mL} /\right.$ poço $)$ foram incubadas com a toxina, em diferentes concentrações $(0,15 \mu \mathrm{g} / \mathrm{mL}$; $0,3 \mu \mathrm{g} / \mathrm{mL} ; 0,6 \mu \mathrm{g} / \mathrm{mL} ; 1,2 \mu \mathrm{g} / \mathrm{mL} ; 2,4 \mu \mathrm{g} / \mathrm{mL}$ e $4,8 \mu \mathrm{g} / \mathrm{mL}$ ) ou apenas com meio de cultura (controle), em placas de cultura de 6 poços em duas situações: 1) tratadas e incubadas por 24 horas ou 2) tratadas por 1 hora, lavadas e incubadas na presença de meio de cultura RPMI $164010 \%$ de $\mathrm{SBF}$, por 24 horas, em estufa à $37{ }^{\circ} \mathrm{C}$ e $5 \%$ de $\mathrm{CO}_{2}$. Após este período, as células foram tripsinizadas, ressuspensas com PBS e com corante azul de Tripan e contadas em câmara de Neubauer.

\subsection{Efeito da CTX sobre a invasão da célula t.End.1 na matriz extracelular}

\subsubsection{Ensaio de migração - Wound healing}

Este ensaio é usado para avaliar o movimento de células no campo vazio criado por uma interrupção na monocamada de cultura de células (DENKER; BARBER, 2002). Foram plaqueadas $1,0 \times 10^{6} / \mathrm{mL}$ de t.End. 1 em placa de 24 poços na presença de meio RPMI $10 \%$ por 1 hora para aderência em coating de colágeno $(10 \mu \mathrm{g} / \mathrm{mL})$. Em seguida foram lavadas e incubadas em meio RPMI 10\%, por até 24 horas ou até a formação da monocamada. Após este período, o meio foi removido e na monocamada foi feita uma interrupção com uma ponteira de $200 \mu \mathrm{L}$, criando um espaço livre de células. Posteriormente, as placas foram lavadas com PBS e incubadas na presença de diferentes concentrações de CTX $(0,15 \mu \mathrm{g} / \mathrm{mL}$, $0,3 \mu \mathrm{g} / \mathrm{mL}, 0,6 \mu \mathrm{g} / \mathrm{mL}, 1,2 \mu \mathrm{g} / \mathrm{mL}$ e $2,4 \mu \mathrm{g} / \mathrm{mL}$ ) ou apenas na presença de meio de cultura (controle), por um período de 1 hora. Em seguida, as células foram lavadas e incubadas na presença de meio de cultura RPMI com SFB $1 \%$ para manter a viabilidade e migração e interromper a proliferação das células (WANG et al., 2009). O ensaio foi avaliado após os períodos de $6 \mathrm{~h}, 12 \mathrm{~h}$ e $24 \mathrm{~h}$ de incubação a $37^{\circ} \mathrm{C}$ e $5 \%$ de $\mathrm{CO}_{2}$. O número de células em migração foi determinado por contagem em 5 campos por poço, utilizando microscopia de luz invertida. Fotomicrografias foram obtidas nos tempos $0 \mathrm{~h}, 6 \mathrm{~h}, 12 \mathrm{~h}$ e $24 \mathrm{~h}$, para posterior análise. Para análise, utilizaremos o modelo descrito em Denker e Barber (2002), com modificações. Inicialmente, a área livre de células foi medida com uma régua e inserida por programa de computador sobre as imagens correspondentes ao tempo e ao tratamento. Em todos os tempos de análise $(0,6,12$ e 24 horas) foram realizadas as mesmas medidas, sendo correspondente a área de células que migraram para o espaço livre. 
Posteriormente, o efeito da CTX foi avaliado sobre a migração celular no modelo de Wound healing após 24 horas de incubação em meio condicionado de cultura de célula tumoral. Para tanto, células da linhagem t.End.1 (1,0x10\% $\mathrm{mL})$ foram plaqueadas e aderidas por $1 \mathrm{~h}$, em placa de cultura de 24 poços contendo lamínulas de vidro de $13 \mathrm{~mm}$ com coating de colágeno I (10 $\mu \mathrm{g} / \mathrm{mL})$, na presença de meio RPMI 10\%. Em seguida, foram lavadas e incubadas em meio RPMI 10\%, por aproximadamente 24 horas, ou até a cultura atingir 90\% de confluência. Após este tempo, o meio foi retirado e na monocamada de células foi feita uma interrupção, com uma ponteira de $200 \mu \mathrm{l}$, com o objetivo de criar uma área livre de células. Posteriormente as placas foram lavadas com PBS e incubadas, por 1 hora, apenas na presença de meio de cultura (controle) ou em meio de cultura contendo a concentração de CTX mais responsiva $(1,2 \mu \mathrm{g} / \mathrm{mL})$. Em seguida, os poços foram lavados com PBS e incubados na presença de meio RPMI contendo 10\% SFB (controle) ou na presença de meio condicionado de células tumorais (estímulo quimiotático), obtido conforme descrito no item 3.4.2, por um período de 24 horas. Após esse tempo, os sobrenadantes foram retirados e os poços foram lavados com PBS e as células foram fixadas pelo método pancrômico de Rosenfeld. As lamínulas foram montadas em lâminas com auxilio de Entelan ${ }^{\circledR}$ (Merck, Darmstast, Germany). Um total de 5 campos aleatórios por lamínula foram contados, em microscópio de campo claro (Standard 25, Carl Zeiss - Alemanha), utilizando-se objetiva de 10x

\subsubsection{Câmara de transwell}

A migração de células endoteliais foi avaliada utilizando o sistema de transwell, empregando membranas de policarbonato com 6,5 mm de diâmetro, e poros de 8,0 $\mu \mathrm{m}$ (Nunc-USA). Essas membranas foram hidradatas com a solução PBS-BSA 0,1 \% por 45 minutos em estufa de $\mathrm{CO}_{2}$. Durante o tempo do bloqueio, culturas semiconfluentes de células t.End.1 foram desprendidas do fundo da garrafa com solução de tripsina/EDTA e ressuspensas em meio RPMI 10\%. Após o bloqueio, foram adicionados ao poço inferior de uma placa de 24 poços $600 \mu 1$ de meio RPMI $2 \%$ (controle) ou $600 \mu 1$ de meio condicionado de cultura de células tumorais, conforme descrito no item 3.4.2, como estímulo quimiotático (GARRIDO et al., 1995; SHIH et al., 2012). Posteriormente, sob o meio, foi colocado o transwell, e em seguida 200 $\mu 1$ de meio RPMI, livre se soro, contendo $1,0 \times 10^{5}$ células, tratadas com CTX $(1,2 \mu \mathrm{g} / \mathrm{mL})$, por 1 hora ou apenas incubadas na presença de meio de cultura (controle), durante o mesmo período, foram colocadas sobre a face superior de transwell. 
Após 5 horas de migração, em estufa com $5 \%$ de $\mathrm{CO}_{2}$, a $37{ }^{\circ} \mathrm{C}$, o transwell foi retirado do poço, e com um cotonete, as células não migrantes foramretiradas da face superior da membrana. O Transwell, contendo as células migrantes foi fixado e corado pelo corante MayGrunwald-Giemsa, modificado por Rosenfeld (1947) por 1 minuto, seguido de uma incubação em águas destilada, previamente fervida, por 10 minutos. Em seguida, as membranas foram recortadas do transwell e montadas em lâminas com auxilio de Entelan ${ }^{\circledR}$. A contagem de células migrantes foi realizada segundo metodologia descrita por Leavesley et al. (1992).

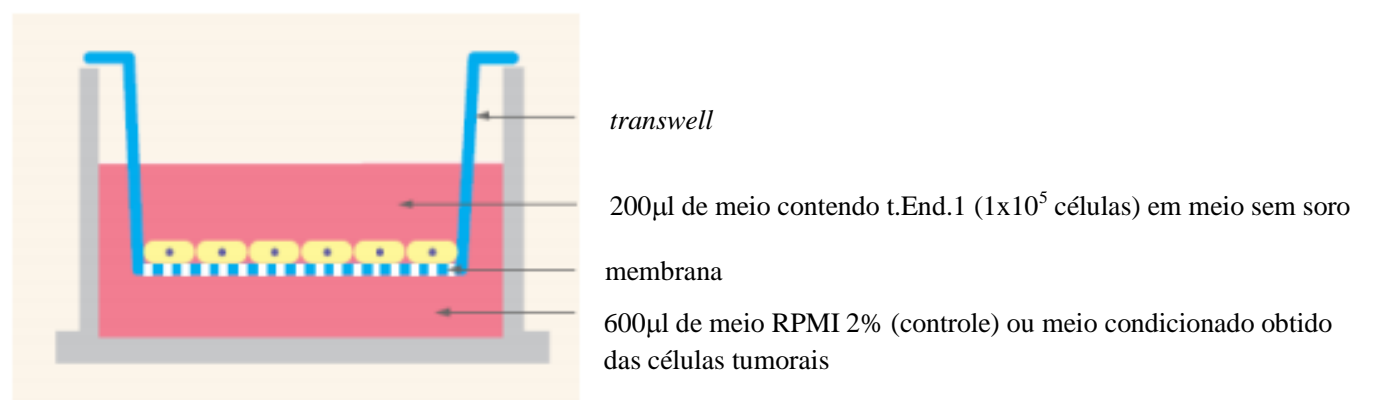

\subsubsection{Ensaio de competição entre a célula endotelial e o ligante natural}

Este ensaio foi realizado para avaliar a capacidade da CTX em inibir a adesão da célula endotelial ao seu ligante. Para os ensaios de competição com o ligante, uma suspensão de células t.End.1 ( $1 \times 10^{5} / 100 \mu \mathrm{L} /$ poço) foi previamente incubada, na ausência ou presença de CTX $(0,6 \mu \mathrm{g} / \mathrm{mL} ; 1,2 \mu \mathrm{g} / \mathrm{mL}$ e $2,4 \mu \mathrm{g} / \mathrm{mL})$, por 1 hora, a $5 \%$ de $\mathrm{CO}_{2}$ a $37{ }^{\circ} \mathrm{C}$. A seguir, a suspensão de células (100 $\mu \mathrm{L} /$ poço) foram adicionadas às placas Nunc Maxsorp® (eBioscience, San Diego, CA, USA), contendo 96 orifícios, previamente sensibilizados com os diferentes componentes de matriz (colágeno tipo I - $10 \mu \mathrm{g} /$ poço [MEEROVICTH et al., 2003]; fibronectina - $3 \mu \mathrm{g} /$ poço [MEEROVICTH et al., 2003] e laminina - $10 \mu \mathrm{g} /$ poço [ZARIC; RÜEGG, 2005]).As células que não aderiram foram removidas dos orifícios através de quatro lavagens consecutivas com PBS. As células aderidas foram incubadas com $30 \mu \mathrm{L}$ de MTT ( $5 \mathrm{mg} / \mathrm{mL}$ ), dissolvido em PBS, por 3 horas e foram adicionados, a seguir, $100 \mu \mathrm{lde}$ SDS $10 \%$, dissolvido em PBS (contendo 0,01 M de $\mathrm{HCl}$ ). As placas foram mantidas na estufa a $37{ }^{\circ} \mathrm{C}$ por 18 horas. Após esse período, foi realizada a leitura espectofotométrica a $595 \mathrm{~nm}$ em leitor de ELISA (Multiskan EX, Labsystem). As curvas padrões foram construídas partindo-se das suspensões de células nas concentrações de $10^{6}$ células/mL, utilizando número 
de células correspondentes a 100, 80, 65, 50, 35, 20 $\mu$ l dessa suspensão. Os experimentos foram realizados em octoplicata. Os valores obtidos pela leitura da absorbância a $595 \mathrm{~nm}$ foram inseridos no programa GraphPad InSTAT; Software V2.01 para a obtenção do número de células finais aderidas.

\subsection{Ensaio da formação de tubos em matrigel no modelo 3D}

Neste ensaio, células t.End.1 $\left(1,5 \times 10^{5}\right)$ foram tratadas ou não com CTX na concentração de $1,2 \mu \mathrm{g} / \mathrm{mL}$ por 1 hora, a $37^{\circ} \mathrm{C}$ e $5 \% \mathrm{CO}_{2}$. Durante o período de tratamento, $50 \mu \mathrm{L}$ de Matrigel (9,3 mg/mL - BD Biosciences, Bedford, MA, EUA) foram adicionados na placa de 96 poços e polimerizados por 45 minutos, em estufa a $37^{\circ} \mathrm{C}$ e $5 \% \mathrm{CO}_{2}$, formando um gel 3D. Após o período de tratamento, células t.End.1 foram centrifugadas para remover o meio de cultura contendo a toxina e ressuspensas em $1 \mathrm{~mL}$ de meio de cultura RPMI a $2 \%$ de SFB. Em seguida, $100 \mu \mathrm{L}\left(1,5 \times 10^{4}\right)$ de células foram adicionadas em cada poço, sobre o matrigel polimerizado e incubadas por 6 horas a $37^{\circ} \mathrm{C}$. Após este período, as imagens foram capturadas em microscópio Nikon Eclipse TS100, equipado com uma câmera DS-Fi2, em objetiva de 10x, utilizando o software Nis-Elements D. Este equipamento fica locado no Laboratório de Parasitologia do Instituto Butantan. Aquantificação foirealizada por meio da contagem do número de estruturas tubulares de 5 campos distintos em cada poço.

\subsection{Ensaio de imunofluorescencia para avaliar o efeito da CTX sobre as integrinas e o citoesqueleto de actina}

Para a reação de imunofluorescencia, foi utilizado células t.End.1 (5,0x10 $/ \mathrm{mL} /$ poço) previamente tratadas ou não com $1,2 \mu \mathrm{g} / \mathrm{mL}$ de CTX, por uma hora, sob coating de fibronectina $(3 \mu \mathrm{g} / \mathrm{mL})$ ou de colágeno tipo I $(10 \mu \mathrm{g} / \mathrm{mL})$ ou de laminina $(10 \mu \mathrm{g} / \mathrm{mL})$ nas lamínulas. Incuba overnight a $37^{\circ} \mathrm{C}, 5 \% \mathrm{CO}_{2}$, na presença de $1 \mathrm{~mL}$ de meio RPMI $2 \%$ de SFB ou na presença de $1 \mathrm{~mL}$ de meio condicionado de célula tumoral MCF-7. Em seguida, as lamínulas foram fixados e permeabilizados em tampão PHEM/Triton-X 0,5\%, sacarose 5\% e paraformoldeído $4 \%$, por 5 minutos, para promover a exposição dos sítios antigênicos a esses anticorpos. Os discos serão lavados em PHEM e glicina (1x) e fixados em paraformoldeído $4 \%$, sacrose $5 \%$, por um período de 20 minutos. As lamínulas foram lavadas novamente em PHEM e glicina (3 vezes a cada 10 minutos) e então foram bloqueadas com NGS (natural goat serum) diluído em PHEM e glicina (1:1) durante 1 hora a temperatura ambiente. Após 
este período, as lamínulas foram incubadas na presença de anticorpos primários conforme a matriz que se encontrava, no coating de colágeno tipo I as lamínulas foram incubadas com anticorpo monoclonal de coelho anti- $\alpha 2$ (Millipore, Billerica, MA, EUA) (diluição 1:500, diluído em 1:100 de soro de cabra em PHEM e glicina) e em coating de fibronectina as lamínulas foram incubadas com anticorpo monoclonal de coelho anti- $\alpha$ v (Millipore, Billerica, MA, EUA), diluição 1:500, diluído em 1:100 de soro de cabra em PHEM e glicina, incubar overnight a temperatura ambiente. Em seguida as lamínulas foram lavadas com PHEM e glicina 3 vezes por 10 minutos e incubadas com anticorpo secundário de cabra anti-coelho (Alexa 488 [Invitrogen, Carlsbad, Canadá]), diluído 1:2000 em tampão de bloqueio, juntamente com faloidina conjugada a Rodamina (Molecular Probes, Burlington, Canadá) (diluído 1:200 em tampão de bloqueio) por período de 1 hora a temperatura ambiente e ausência de luz. As lamínulas foram lavadas 3 vezes com PHEM e glicina por período de 10 minutos por lavagem. Montagem da lamina com Vectashield (Vector Labs, Burlingame, CA, EUA) e observadas a 40x no microscópio confocal do Laboratório de Parasitologia do Instituto Butantan.

\subsection{Análise estatística}

Os valores serão expressos como média \pm e.p.m. (erro padrão da média) e analisados estatisticamente por ANOVA e teste de Tukey-Kramer (INSTAT - GraphPad Software), comparando-se os valores do grupo controle com os valores dos experimentais. Para essas análises, bem como para elaboração dos gráficos foi utilizado o programa GraphPad Prism vs 4.0.As diferenças serão consideradas significativas para o nível de $\mathrm{p}<0,05$ (5\%). 


\section{RESULTADOS}

\subsection{Efeito in vitro da CTX sobre a proliferação célula endotelial (t.End.1)}

Inicialmente, a ação da CTX sobre a capacidade proliferativa das células endoteliais foi avaliada após um período de $24 \mathrm{~h}$ de incubação com diferentes concentrações da CTX $(0,15 \mu \mathrm{g} / \mathrm{mL}, 0,3 \mu \mathrm{g} / \mathrm{mL}, 0,6 \mu \mathrm{g} / \mathrm{mL}, 1,2 \mu \mathrm{g} / \mathrm{mL}, 2,4 \mu \mathrm{g} / \mathrm{mL}$ e $4,8 \mu \mathrm{g} / \mathrm{mL})$. Conforme demonstrado na Figura 3A, após 24 horas de incubação, a CTX acarretou significativa inibição da proliferação das células endoteliais nas concentrações de 0,3 $\mu \mathrm{g} / \mathrm{mL}(29 \%), 0,6$ $\mu \mathrm{g} / \mathrm{mL}$ (38\%), 1,2 $\mu \mathrm{g} / \mathrm{mL}$ (62\%), 2,4 $\mu \mathrm{g} / \mathrm{mL}$ (44\%) e 4,8 $\mu \mathrm{g} / \mathrm{mL}$ (24\%),quando comparado ao grupo controle incubado apenas na presença do meio RPMI 1640. A concentração de 0,15 $\mu \mathrm{g} / \mathrm{mL}$ não interferiu com o número de células, quando comparada aos valores obtidos no grupo controle (Figura 3A).

Após a avaliação da capacidade da CTX em interferir com a capacidade proliferativa de células tumorais, após a incubação por 24 h, avaliamos se, da mesma forma que observado em outros estudos, a incubação rápida na presença da CTX acarretaria o mesmo efeito inibitório observado. Assim, as células endoteliais foram incubadas na presença das mesmas concentrações de CTX, por um período de $1 \mathrm{~h}$ (Figura 3B). Os resultados demonstraram que nestas condições experimentais a CTX inibiu significativamente a capacidade proliferativa das células endoteliais nas concentrações de 0,6 $\mu \mathrm{g} / \mathrm{mL}$ (39\%), 1,2 $\mu \mathrm{g} / \mathrm{mL}(61 \%), 2,4 \mu \mathrm{g} / \mathrm{mL}$ (51\%), 4,8 $\mu \mathrm{g} / \mathrm{mL}$ (27\%), quando comparado ao grupo controle tratado apenas com meio RPMI 1640. As concentrações de $0,15 \mu \mathrm{g} / \mathrm{mL}$ e $0,3 \mu \mathrm{g} / \mathrm{mL}$ apresentaraminibição de $17 \%$, $18 \%$, respectivamente, porém não foram consideradasestatisticamente significativa (Figura 3B).

Em ambos os ensaios, a viabilidade celular tanto do controle quanto das células incubadas em diferentes concentrações da CTX (avaliada pelo teste de exclusão por azul de Tripan 1\%) apresentou sempre acima de $98 \%$ (dados não mostrados). 
Figura 3 - Efeito in vitroda CTX sobre a proliferação das células endoteliais t.End.1.

A)

\author{
Proliferação - Ensaio de 24 horas
}

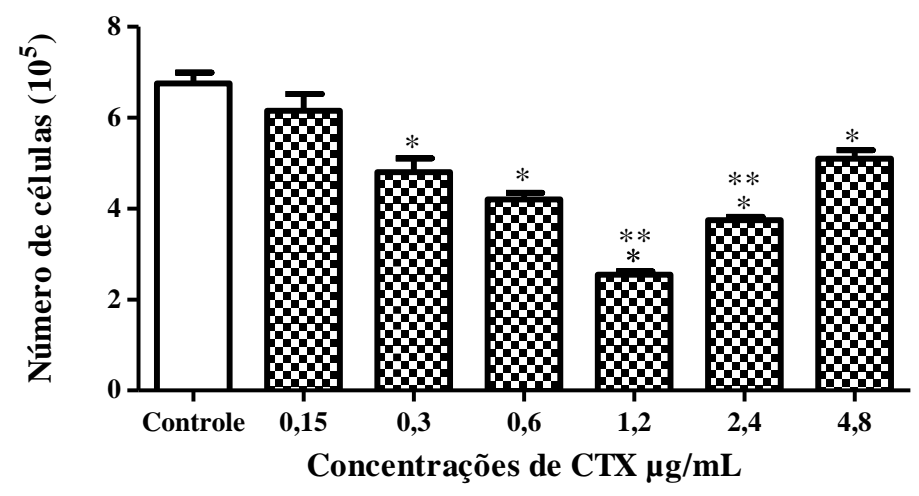

B)

Proliferação - Ensaio de 1 hora

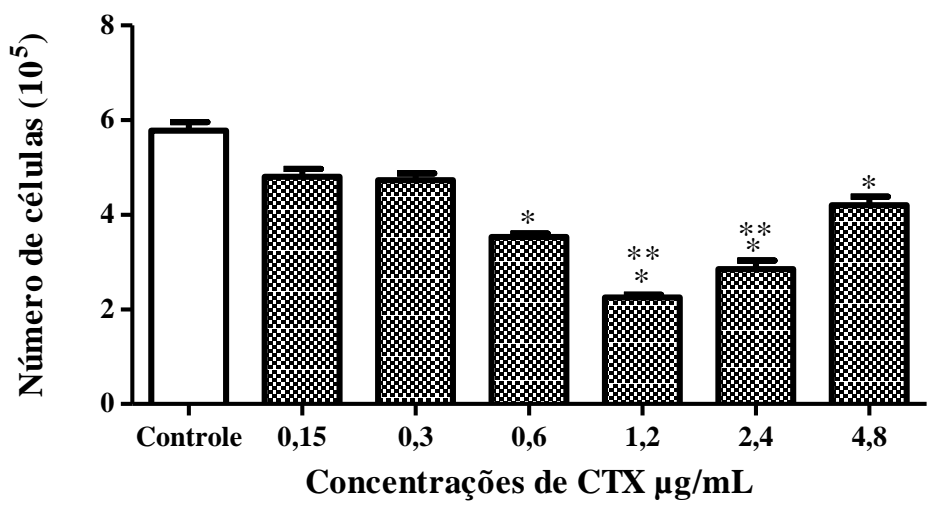

Células da linhagem t.End.1 (5,0x10 $/ \mathrm{mL} /$ poço $)$ foram plaqueadas e aderidas por 1 hora, em placa de cultura de 6 poços na presença de meio RPMI 10\%. Em seguida foram lavadas e: A) incubadas apenas na presença de meio de cultura (controle) ou em meio de cultura contendo as diferentes concentrações de CTX $(4,8 \mu \mathrm{g} / \mathrm{poço;}$ $2,4 \mu \mathrm{g} / \mathrm{poço} ; 1,2 \mu \mathrm{g} / \mathrm{poço} ; 0,6 \mu \mathrm{g} / \mathrm{poço} ; 0,3 \mu \mathrm{g} /$ poço, $0,15 \mu \mathrm{g} /$ poço), por 24 horas ou B) incubadas apenas na presença de meio de cultura (controle) ou em meio de cultura contendo as diferentes concentrações de CTX

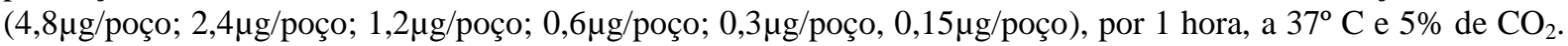
Após este período as placas foram lavadas e incubadas na presença apenas de meio RPMI 1640, por 24 horas a $37^{\circ} \mathrm{C}$ e $5 \%$ de $\mathrm{CO}_{2}$. Os resultados estão expressos como Número de Células e representam a média \pm e.p.m. para 6 amostras por grupo e representam 3 ensaios distintos. $* \mathrm{P}<0,05$ por comparação com o grupo incubado apenas com o meio (controle).** $\mathrm{P}<0,05$ por comparação com os grupos incubados com as demais concentrações de CTX. 


\subsection{Efeito da CTX sobre a adesão de células endoteliais (t.End.1) em diferentes ligantes da matriz extracelular}

Para investigar a ação da CTX em relação à adesão da célula endotelial em diferentes ligantes naturais, foram utilizadas as principais concentraçõesda toxina que induziram inibição sobre a capacidade proliferativa das células endoteliais.

Como demonstrado na Figura 4A, as concentrações de $0,6 \mu \mathrm{g} / \mathrm{mL}, 1,2 \mu \mathrm{g} / \mathrm{mL}$ e 2,4 $\mu \mathrm{g} / \mathrm{mL}$ de CTX inibiram significativamente $(47 \%, 64 \%$ e $72 \%$, respectivamente) a adesão das células endoteliais ao colágeno tipo I $(10 \mu \mathrm{g} / \mathrm{mL})$, quando comparada ao grupo controle (Figura 4A).

Já, em relação à adesão à fibronectina $(3 \mu \mathrm{g} / \mathrm{mL})$, a CTX acarretou inibição significativa das células endoteliais nas concentrações de $1,2 \mu \mathrm{g} / \mathrm{mL}(33 \%)$ e $2,4 \mu \mathrm{g} / \mathrm{mL}$ (28\%), em relação ao controle (Figura 4B).

Outro componente avaliado foi a laminina $(10 \mu \mathrm{g} / \mathrm{mL})$. A Figura 4C demonstra que, diferentemente ao observado para os outros componentes de matriz, as células endoteliais apresentaram menor adesão à laminina. Ainda, o efeito inibitório da CTX foi observado apenas para a concentração de 1,2 $\mu \mathrm{g} / \mathrm{mL}$ (55\%), em relação ao controle (Figura 4C). 


\section{Figura 4 - Efeito da CTX sobre adesão celular em diferentes componentes de matriz extracelular}

A

Colágeno tipo I $(10 \mu \mathrm{g} / \mathrm{mL})$

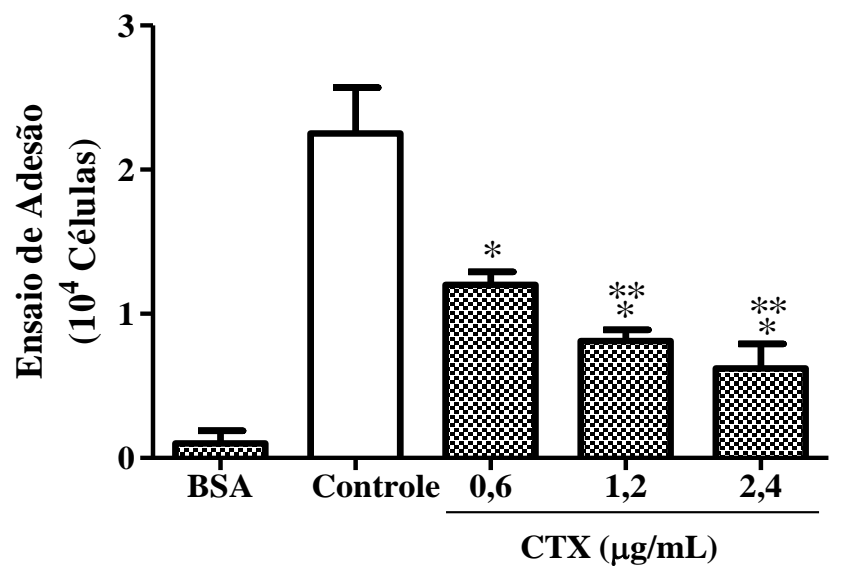

B

\author{
Fibronectina $(3 \mu \mathrm{g} / \mathrm{mL})$
}

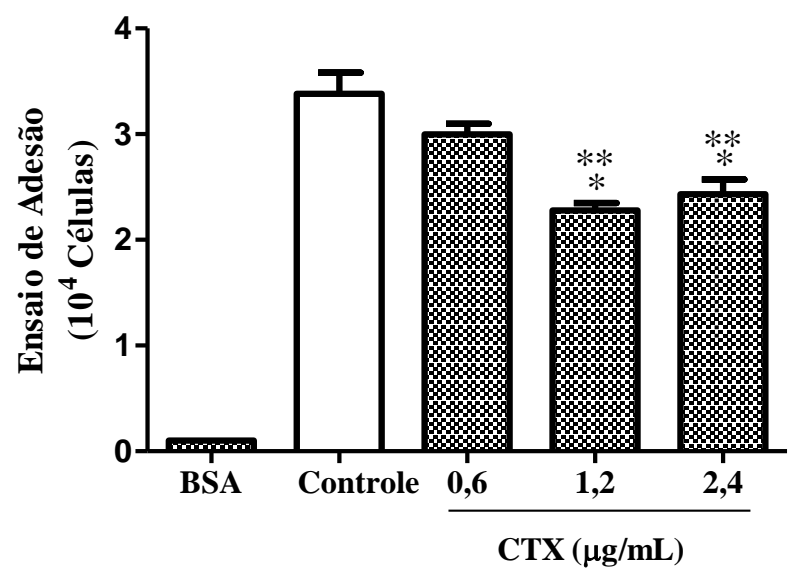

C Laminina $(10 \mu \mathrm{g} / \mathrm{mL})$

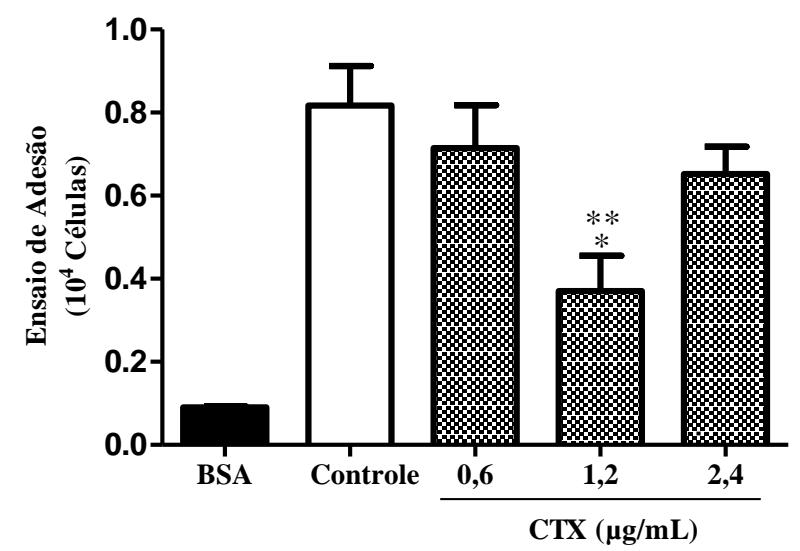

As placas sensibilizadas com os diferentes componentes de matriz receberam uma suspensão de células t.End.1 $\left(1 \times 10^{5}\right.$ células $\left./ 100 \mu \mathrm{L}\right)$, previamente incubadas, na ausência ou presença de diferentes concentrações de CTX $(0,6 \mu \mathrm{g} ; 1,2 \mu \mathrm{g}$ e $2,4 \mu \mathrm{g} / \mathrm{mL})$, por 1 hora, a $37^{\circ} \mathrm{C}$ e $5 \%$ de $\mathrm{CO}_{2}$. Após este período, as células foram centrifugadas, ressuspensas em PBS $(1 \mathrm{~mL})$. Em seguida, $100 \mu \mathrm{L}$ das suspensões celulares foram adicionadas às placas por mais 1 hora, a $37^{\circ} \mathrm{C}$ e $5 \%$ de $\mathrm{CO}_{2}$. Em seguida, os poços foram lavados com PBS e incubados com $100 \mu \mathrm{L}$ meio de cultura e com $30 \mu \mathrm{L}$ de MTT $(5 \mathrm{mg} / \mathrm{mL})$, dissolvido em PBS, por 3 horas e foram adicionados, a seguir, 100 $\mu \mathrm{l}$ de SDS $10 \%$, dissolvido em PBS (contendo 0,01 M de $\mathrm{HCl}$ ). As placas foram mantidas na estufa a $37^{\circ} \mathrm{C}$ e $5 \%$ de $\mathrm{CO}_{2}$. Após 18 horas foi realizada a leitura da placa em leitor de ELISA (Multiscan), absorbância em $595 \mathrm{~nm}$. Em A, B e C: $* \mathrm{P}<0,05$, significativamente diferente por comparação com o grupo de controle. $* * \mathrm{P}<0,05$, significativamente diferente em $\mathbf{A}$ ), para as concentrações $1,2 \mu / \mathrm{mL}$ ou $2,4 \mu \mathrm{g} / \mathrm{mL}$ em comparação com a concentração de 0,6 $\mu \mathrm{g} / \mathrm{mL}$ de CTX; em B), por comparação com a concentração de $0,6 \mu \mathrm{g} / \mathrm{mL}$ de CTX; em C), por comparação com as concentrações $1,2 \mu / \mathrm{mL}$ ou $2,4 \mu \mathrm{g} / \mathrm{mL}$ de CTX. 


\subsection{Efeito da CTX na migração da célula endotelial}

\subsubsection{Migração no modelo de Wound healing}

Neste ensaio, o wound healing foi utilizado para avaliar o movimento das células endoteliais no campo vazio criado por uma interrupção na monocamada celular. Em seguida as células foram tratadas com diferentes concentrações da CTX, por 1 hora. Após esse período, as células foram lavadas e incubadas apenas em meio de cultura por 6, 12 e 24 horas. Conforme demonstrado na Figura 5A, após 6 h de cultura foi observada ação inibitória significativa da CTX sobre a migração das células endoteliais nas concentrações de 1,2 $\mu \mathrm{g} / \mathrm{mL}$ e $2,4 \mu \mathrm{g} / \mathrm{mL}$ (59\% e $33 \%$, respectivamente), quando comparado com o controle no mesmo período. Ainda, no período de 6 horas, pode-se observar que a concentração de 1,2 $\mu \mathrm{g} / \mathrm{mL}$ da CTX inibiu, significativamente, a migração celular, quando comparada com as concentrações de $0,15 \mu \mathrm{g} / \mathrm{mL}$ (55\%); 0,3 $\mu \mathrm{g} / \mathrm{mL}$ (54\%); 0,6 $\mu \mathrm{g} / \mathrm{mL}(46 \%)$ e 2,4 $\mu \mathrm{g} / \mathrm{mL}$ (39\%) (Figura 5A).

No período de 12 horas, a ação inibitória das concentrações de $1,2 \mu \mathrm{g} / \mathrm{mL}$ e $2,4 \mu \mathrm{g} / \mathrm{mL}$ foi novamente significante, quando comparadas com as concentrações de $0,15 \mu \mathrm{g} / \mathrm{mL}$ ( $49 \%$ e $38 \%$, respectivamente), e $0,3 \mu \mathrm{g} / \mathrm{mL}$ (49\% e 39\%, respectivamente) (Figura 5A). Após 24 horas de incubação, a migração das células apresentou-se significativamente inibidas quando pré-tratadas com as concentrações de $1,2 \mu \mathrm{g} / \mathrm{mL}$ e $2,4 \mu \mathrm{g} / \mathrm{mL}$ ( $47 \%$ e $47 \%$, respectivamente), quando comparadas ao controle e à concentração de $0,15 \mu \mathrm{g} / \mathrm{mL}$ (Figura 5A).

A Figura 5B é representativa dos resultados obtidos no período de 24 horas de cultura, após o pré-tratamento de uma hora com $1,2 \mu \mathrm{g} / \mathrm{mL}$ de CTX. O tempo 0 horas corresponde ao período em que a monocamada foi interrompida. Após 24 horas é observada migração das células endoteliais para o campo vazio e com o pré-tratamento de 1 hora com a CTX houve diminuição da migração das células. 
Figura 5 - Efeito da CTX sobre a migração da t.End.1 no modelo de Wound healing em diferentes períodos de tratamento

A)

\section{Ensaio de Wound healing}

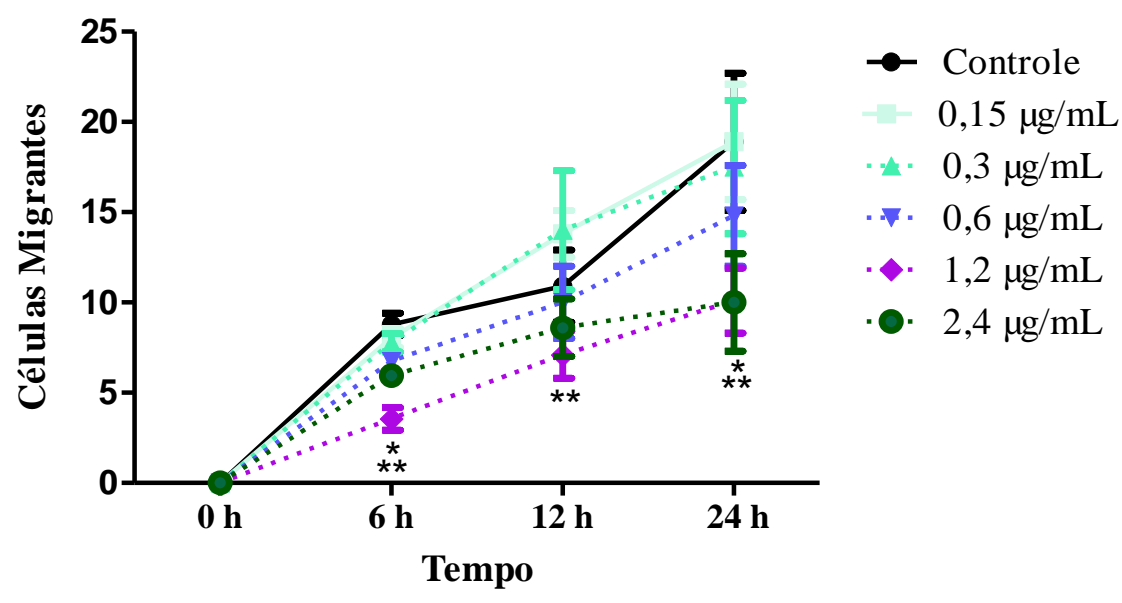

B)

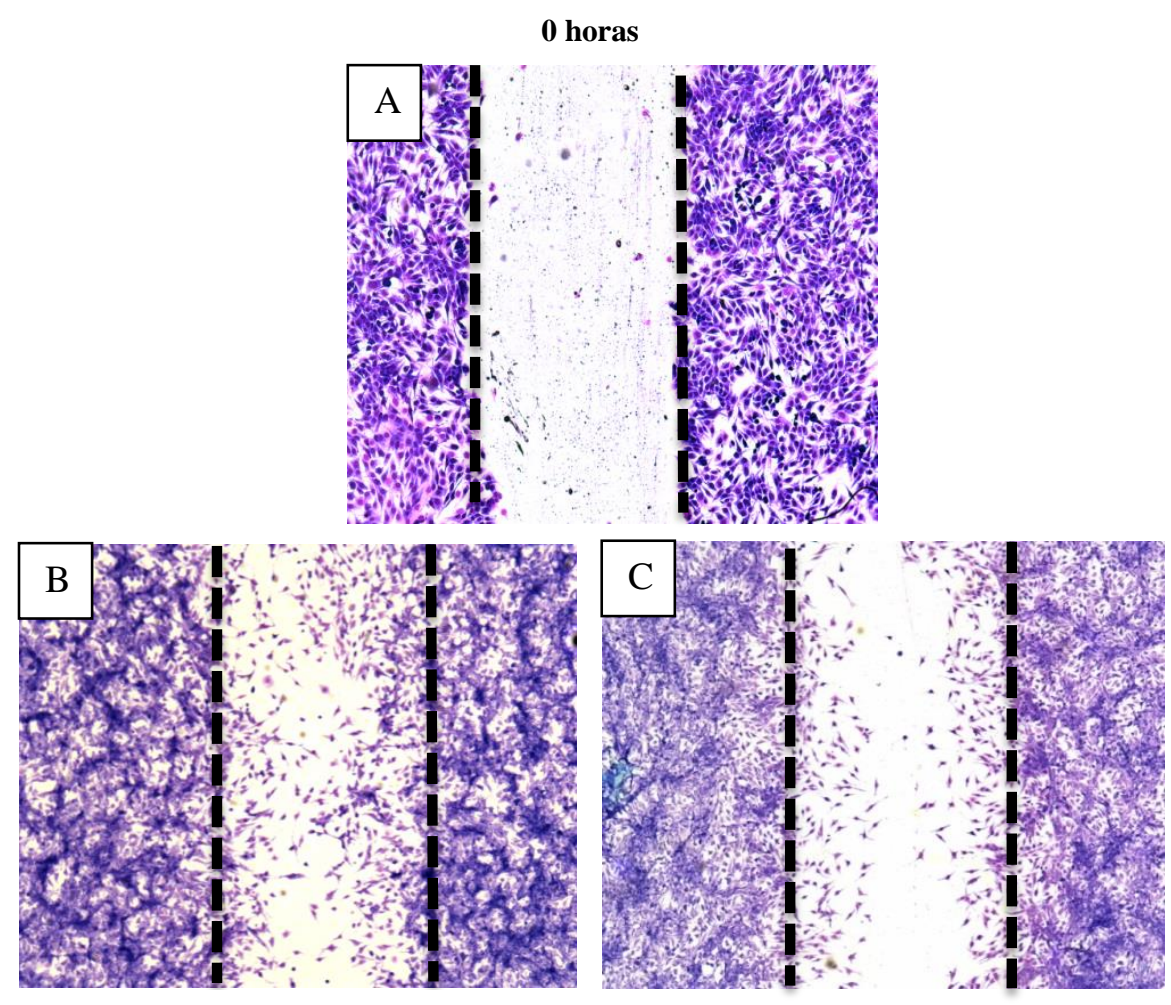

Controle 24h

CTX 24h 
Células da linhagem t.End.1 foram plaqueadas 5,0x10 $/ \mathrm{mL}$ em placa de 24 poços contendo lamínulas de vidro com coating de colágeno tipo I $(10 \mu \mathrm{g} / \mathrm{mL})$ na presença de meio RPMI $10 \%$ por 1 hora para aderência. Em seguida foram lavadas e incubadas em meio RPMI 10\%, por até 24 horas ou até a formação da monocamada com $90 \%$ de confluência. Após este período, o meio foi removido e na monocamada de células foi feita uma interrupção com uma ponteira de $200 \mu \mathrm{L}$, criando um espaço livre de células. Posteriormente, as placas foram lavadas com PBS e tratadas, ou não, com diferentes concentrações de CTX $(0,15 \mu \mathrm{g} / \mathrm{mL}, 0,3 \mu \mathrm{g} / \mathrm{mL}, 0,6 \mu \mathrm{g} / \mathrm{mL}$, $1,2 \mu \mathrm{g} / \mathrm{mL}$ e $2,4 \mu \mathrm{g} / \mathrm{mL}$ ) nos períodos de tempo de $0 \mathrm{~h}, 6 \mathrm{~h}, 12 \mathrm{~h}$ e $24 \mathrm{~h}$ de incubação a $37^{\circ} \mathrm{C}$ e $5 \%$ de $\mathrm{CO}_{2}$. Após esse tempo, os sobrenadantes foram retirados e os poços foram lavados com PBS e as células foram fixadas pelo método pancrômico de Rosenfeld. Os resultados estão expressos como Número de Células Migradas e representam a média \pm e.p.m. para 5 amostras por grupo e representam 2 ensaios distintos. ${ }^{*} \mathrm{P}<0,05$ por comparação com o grupo incubado apenas com o meio (controle). ${ }^{*} \mathrm{P}<0,05$ por comparação com os grupos incubados com as demais concentrações de CTX. As Fotomicrografias foram obtidas nos tempo 0 hora e 24 horas no aumento de 10x. As imagens foram coletadas em microscópio Olympus BX 51, utilizando o programa Image-Pro Plus 5.1, em objetiva de 10x. 


\subsubsection{Efeito da CTX na migração celular no modelo de Wound healing induzida por estímulo tumoral}

Neste ensaio, foi avaliado o efeito da CTX na concentração $1,2 \mu \mathrm{g} / \mathrm{mL}$ (responsável pelo maior efeito da CTX) sobre a migração das células endoteliais, avaliada após 1 hora de tratamento e 24 horas de cultura na presença de meio condicionado da linhagem de células tumorais MCF-7. Como controle, foi utilizado o mesmo meio de cultivo da célula tumoral (meio de cultura RPMI com SFB a 10\%).

A Figura 6A demonstra quea CTX, nesta concentração, inibiu significativamente (52\%) a migração das células endoteliais, previamente tratadas por 1 hora na presença da CTX e posteriormente incubada na presença de meio RPMI a 10\% de SFB. A utilização do meio condicionado obtido de cultura de células tumorais MCF-7, nas mesmas condições experimentais acarretou aumento de 59\% da capacidade migratória de t.End.1 (Figura 6A), quando comparado ao estímulo de meio RPMI com SFB 10\%. Quando células endoteliais foram pré-tratadas com a CTX e submetidas ao ensaio de migração sob o estímulo tumoral, por $24 \mathrm{~h}$, foi observado marcante efeito inibitório (81\%), em relação às células controles, tratadas apenas com meio de cultura e em relação às células tratadas com CTX e incubadas, por 24 horas na presença de meio de cultura com 10\% de SFB (Figura 6A).

A Figura 6B é representativa das células controles e tratadas com CTX estimuladas com meio RPMI 1640 com SFB a 10\% (Painéis A e B) e células controles e tratadas com CTX estimuladas com meio condicionado obtido de cultura de células tumorais MCF-7 (Painéis C e D). 
Figura 6 - Efeito da CTX sobre a migração celular avaliada no modelo de Wound healing após 24 horas de incubação em meio condicionado de cultura de célula tumoral

A)

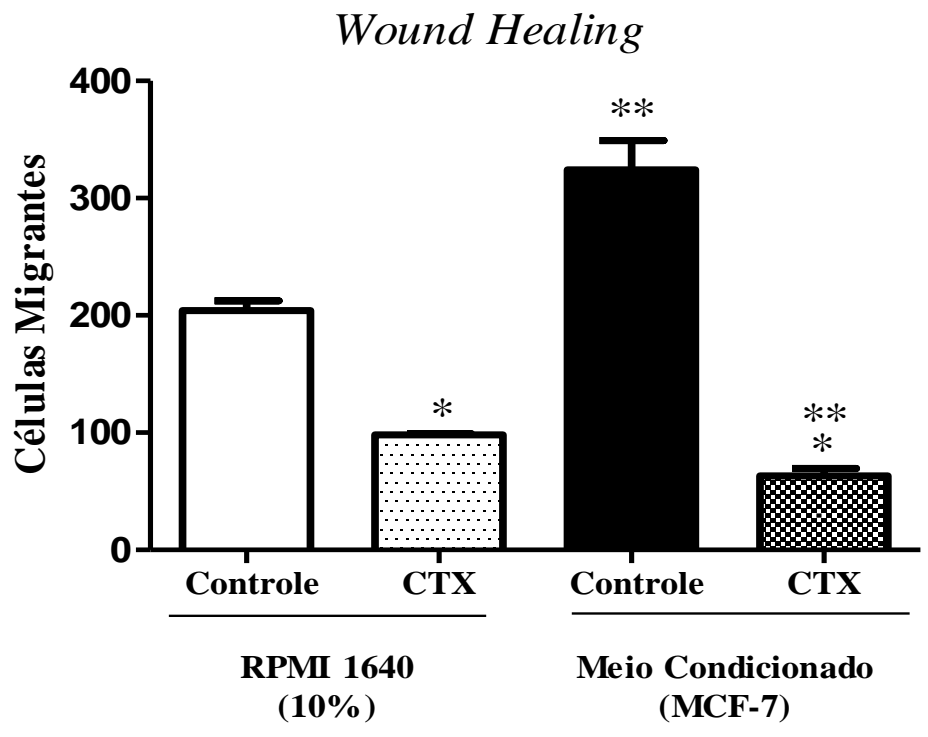

B)

Controles

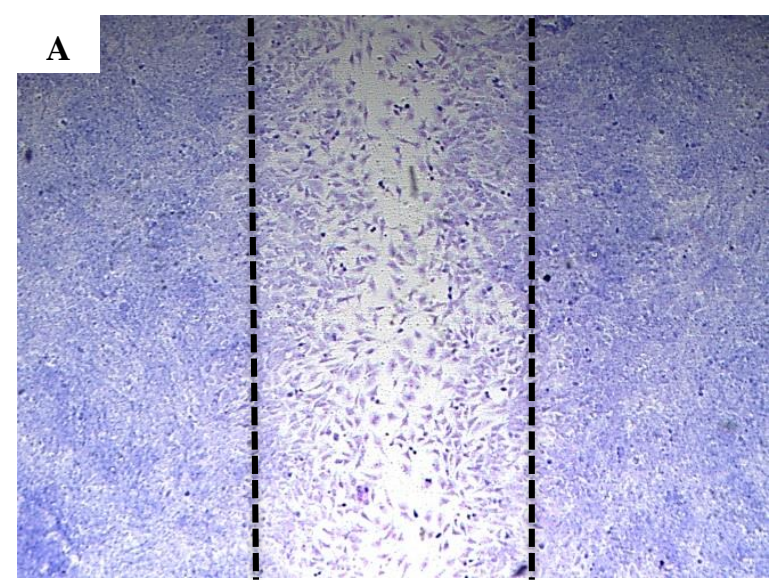

\section{C}

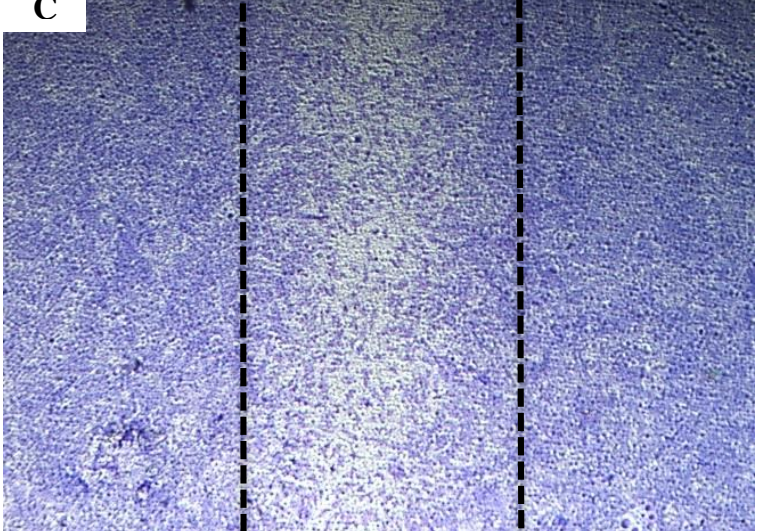

B

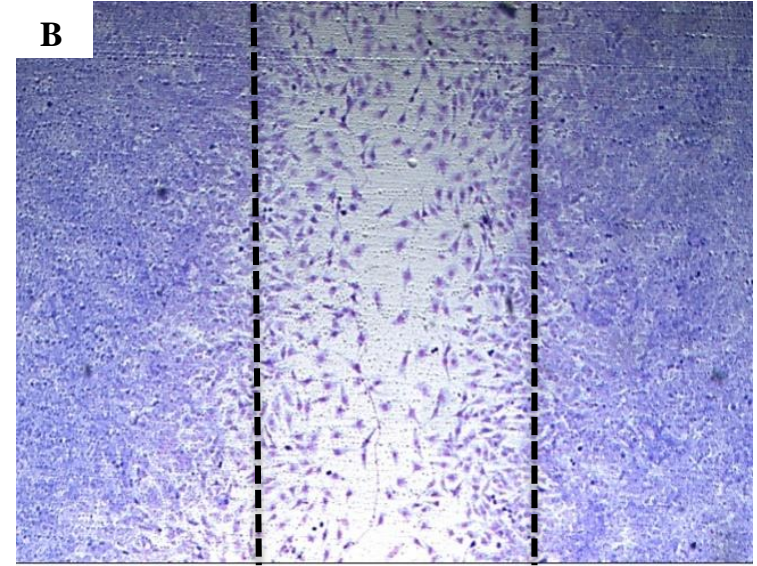

D

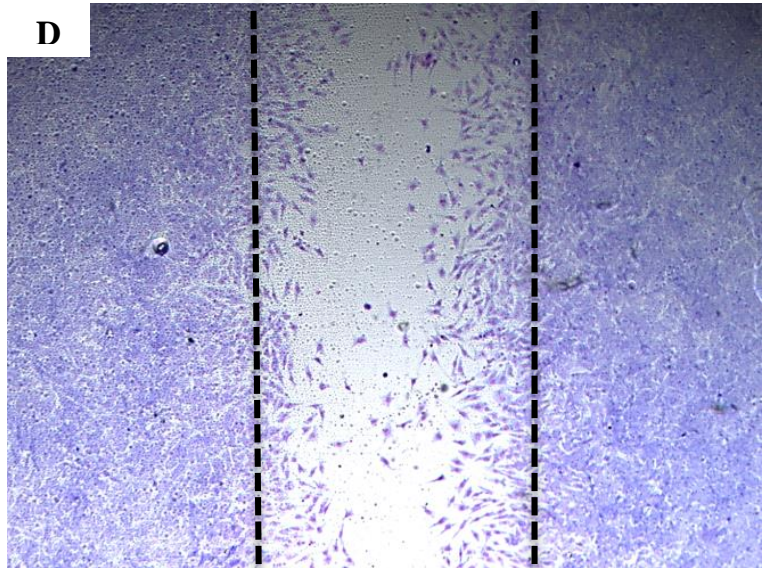


Células da linhagem t.End.1 $\left(5,0 \times 10^{4} / \mathrm{mL}\right)$ foram plaqueadas e aderidas por $1 \mathrm{~h}$, em placa de cultura de 24 poços contendo lamínulas de vidro de $13 \mathrm{~mm}$ com coating de colágeno I $(10 \mu \mathrm{g} / \mathrm{mL})$, na presença de meio RPMI $10 \%$. Em seguida, foram lavadas e incubadas em meio RPMI 10\%, por aproximadamente 24 horas, ou até a cultura atingir $90 \%$ de confluência. Após este tempo, o meio foi retirado e na monocamada de células foi feita uma interrupção, com uma ponteira de $200 \mu \mathrm{l}$, com o objetivo de criar uma área livre de células. Posteriormente as placas foram lavadas com PBS e incubadas apenas na presença de meio de cultura (controle) ou em meio de cultura contendo CTX $(1,2 \mu \mathrm{g} / \mathrm{mL})$, por 1 hora. Em seguida, os poços foram lavados com PBS e incubados na presença de meio RPMI contendo 10\% SFB (controle) ou na presença de meio condicionado de células tumorais (estímulo quimiotático), por um período de 24 horas. Após esse tempo, os sobrenadantes foram retirados e os poços foram lavados com PBS e as células foram fixadas pelo método pancrômico de Rosenfeld. Um total de 5 campos aleatórios por lamínula foram contados, em microscópio de campo claro (Standard 25, Carl Zeiss Alemanha), utilizando-se objetiva de 10x As imagens representadas nos Painéis A, B, C e D, foram obtidas em objetiva de 5x. Painel A representa células controle incubadas em meio RPMI 1640 com 10\% SFB; Painel B representa células tratadas com CTX e incubadas em meio RPMI 1640 com 10\% SFB; Painel C representa células controle incubadas em meio condicionado obtido de células tumorais MCF-7 e Painel D representa células tratadas com CTX e incubadas meio condicionado obtido de células tumorais MCF-7 . Os resultados estão expressos como Número de Células Migrantes e representam a média \pm e.p.m. para 4 amostras por grupo e representam 2 ensaios distintos. *p<0,001 por comparação com os respectivos grupos controles. **p<0,001 por comparação com o grupo controle incubado apenas com o meio RPMI 1640 com 10\% SFB. 


\subsubsection{Efeito da CTX sobre a quimiotaxia no modelo de câmara de transwell}

Neste ensaio, foi realizada por meio da câmara de transwell, a migração direcional in vitro da célula endotelial para um gradiente de quimioatrativos solúveis, migração conhecida como quimiotaxia. Para tanto, como quimioatrativos, foram utilizados o meio condicionado da linhagem de células tumorais mamáriashumana, MCF-7, que apresenta alta atividade secretória de diversas substâncias, incluindo as quimiocinas e, para controle negativo, meio RPMI 2\% de SFB. A concentração da CTX utilizada foi a que apresentou o melhor efeito inibitório em todos os períodos de tempo do ensaio de wound healing, a 1,2 $\mu \mathrm{g} / \mathrm{mL}$.

Como mostra a Figura 7A, as células endoteliais tratadas previamente com CTX por 1 hora apresentaram inibição de $24 \%$ do número de células migradas na presença de meio RPMI 2\%, porém essa diferença não foi estatisticamente significativa quando comparada com o grupo controle (Painéis A e B).

Em relação ao grupo controle, sobestímulo demeio condicionado de célula tumoral, houve aumento da migração celular quando comparado ao grupo controle estimulado com meio RPMI 2\%. Além disso, as células que foram pré-incubadas na presença de $1,2 \mu \mathrm{g} / \mathrm{mL}$ de CTX por uma hora, acarretou $42 \%$ de inibição da migração celular frente o estímulo tumoral quando comparadas ao grupo controle (Painéis C e D)

Com este ensaio, também foi possível observar a projeção do corpo celular da t.End.1 nos diferentes quimioatrativos. Uma vez que as células se encontram em condições fisiológicas, o núcleo celular está mais arredondado e o citoesqueleto alongado enquanto que quando as células se encontram no microambiente tumoral, o núcleo não é evidente e o corpo celular está mais achatado e houve maior polimerização do citoesqueleto de actina. 
Figura 7 - Efeito da CTX sobre a migração das células endoteliais em câmara de Transwell

A)

Ensaio de Quimiotaxia

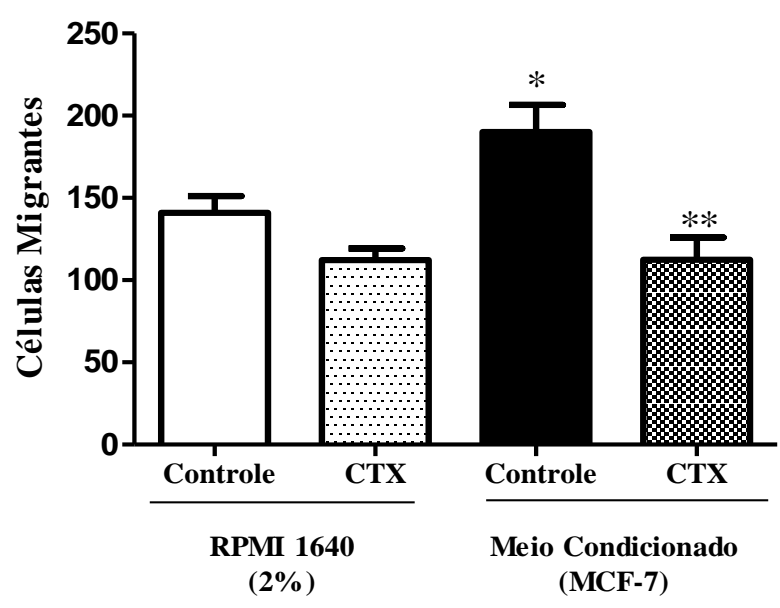

B)
Controles
CTX

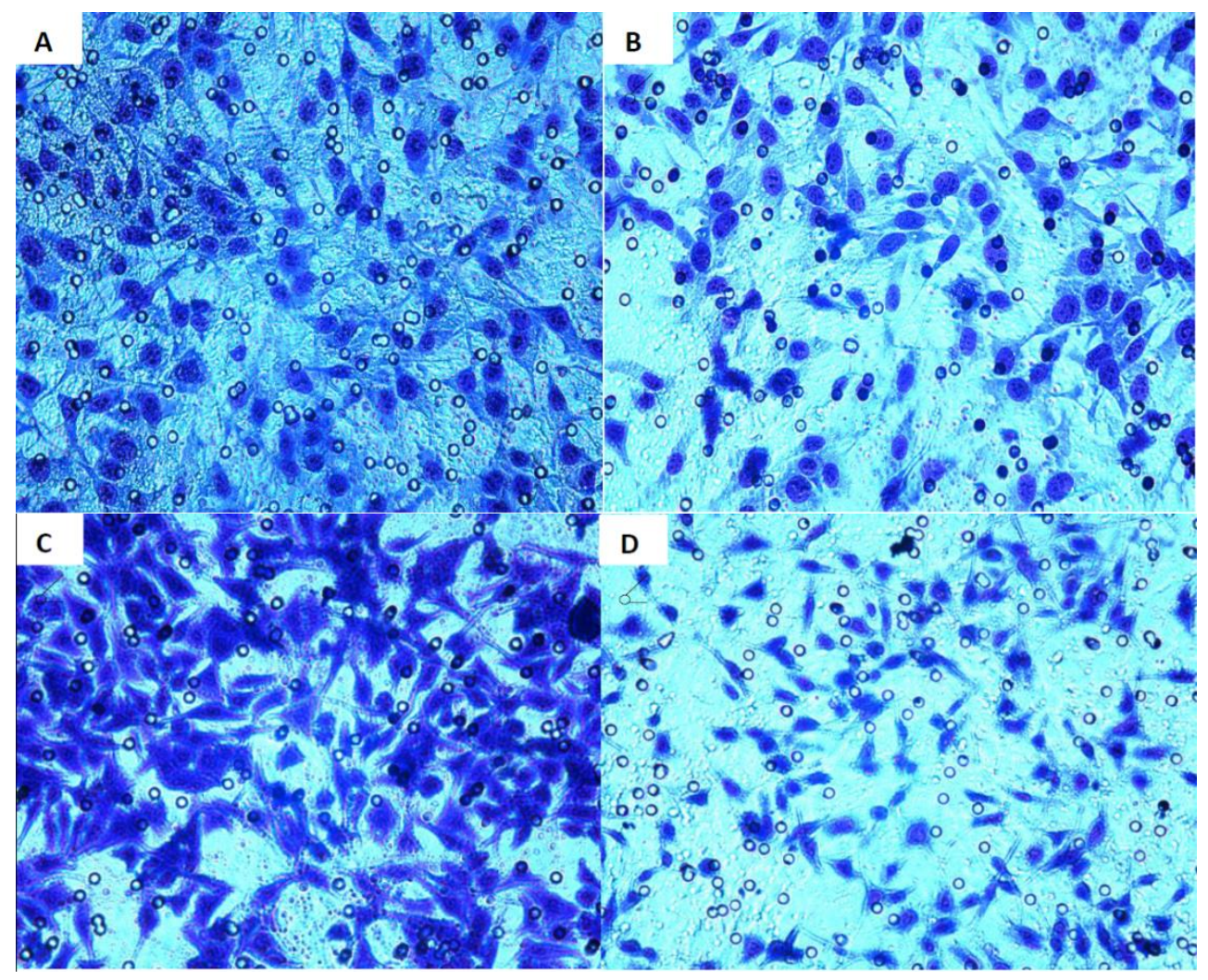


Células da linhagem t.End.1 $\left(1 \times 10^{6} / \mathrm{mL}\right)$ incubadas em meio RPMI sem soro (controle) ou em meio de cultura sem soro, contendo CTX $(1,2 \mu \mathrm{g} / \mathrm{mL})$, por 1 hora, a $37^{\circ} \mathrm{C}$ e $5 \%$ de $\mathrm{CO}_{2}$. Após este período, as células foram centrifugadas e ressuspensas em $2 \mathrm{~mL}$ de meio RPMI 1640 fresco, sem soro. Em seguida, $200 \mu \mathrm{L}$ desta suspensão celular contendo $1 \times 10^{5}$ foram adicionados sobre a face superior da membrana do transwell contidos em placas de 24 poços adicionados de $600 \mu \mathrm{l}$ de meio RPMI 2\% (controle) ou o mesmo volume de meio condicionado de cultura de células tumorais da linhagem MCF-7. Após 5 horas de incubação, a $37^{\circ} \mathrm{C}$ e $5 \%$ de $\mathrm{CO}_{2}$, o número de células em migração foi determinado por contagem em 5 campos aleatórios, por membrana, utilizando microscopia de luz. Os resultados estão expressos como Células Migrantes e representam a média \pm e.p.m. para 5 campos por grupo e representam 2 ensaios distintos. $* \mathrm{P}<0,001$ por comparação com o grupo incubado apenas com o meio (controle). ${ }^{*} \mathrm{P}<0,01$ por comparação com o grupo incubado com meio condicionado. Os painéis são representativos da quimiotaxia das células t.End.1: A) controle em resposta ao meio RPMI 1640 com SFB 2\%; B) CTX em resposta ao meio RPMI 1640 com SFB 2\%; C) controle em resposta ao meio condicionado das células tumorais MCF-7; D) CTX em resposta ao meio condicionado das células tumorais MCF-7. As imagens foram coletadas em microscópio Olympus BX 51, utilizando o programa Image-Pro Plus 5.1, em objetiva de 40x. 


\subsection{Efeito da CTX sobre a angiogênese in vitro no matrigel 3D}

Neste ensaio, foi avaliado o efeito da CTX sobre as células endoteliais em formar estruturas do tipo capilares in vitro na presença de meio de cultura RPMI 1604 a 2\% de SFB (Figura 8). O grupo controle apresentou rápida formação de estruturas do tipo capilar a partir da $2^{\mathrm{a}}$ hora de incubação (dados não mostrados) e, a partir da $6^{\mathrm{a}}$ hora, houve formação de redes com estruturas alongadas e finas estabelecendo o contato célula-célula (Figura 8A).

Células endoteliais pré-tratadas com $1,2 \mu \mathrm{g} / \mathrm{mL}$ de CTX por $1 \mathrm{~h}$, apresentaram diminuição da formação de estruturas do tipo capilares em $66 \%$ em relação ao controle após a

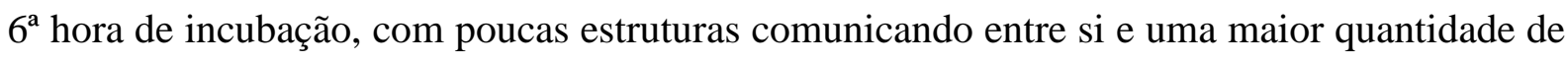
células com o corpo celular retraído (Figura 8B). 
Figura 8 - Efeito da CTX sobre a formação de estruturas do tipo tubulares no matrigel

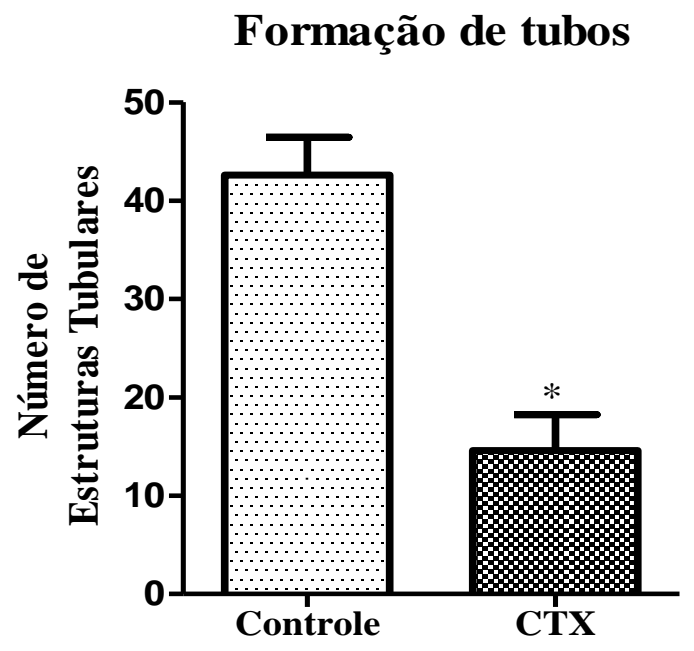

Controle

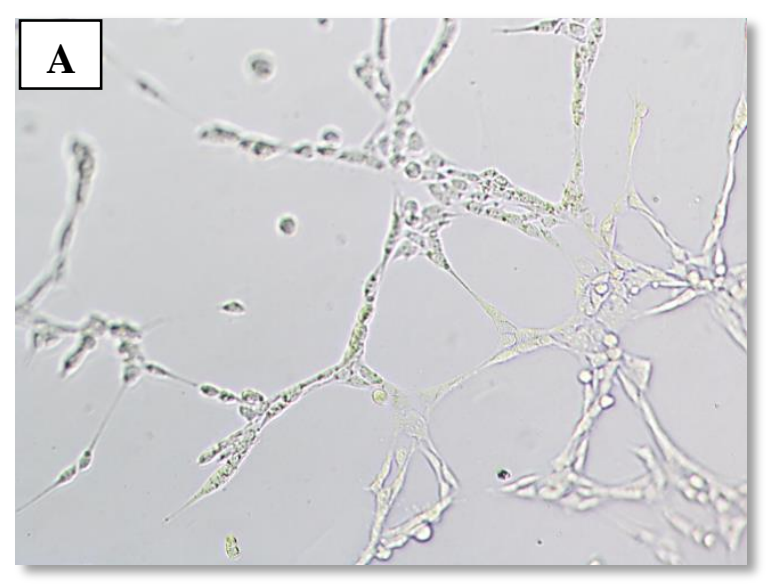

CTX

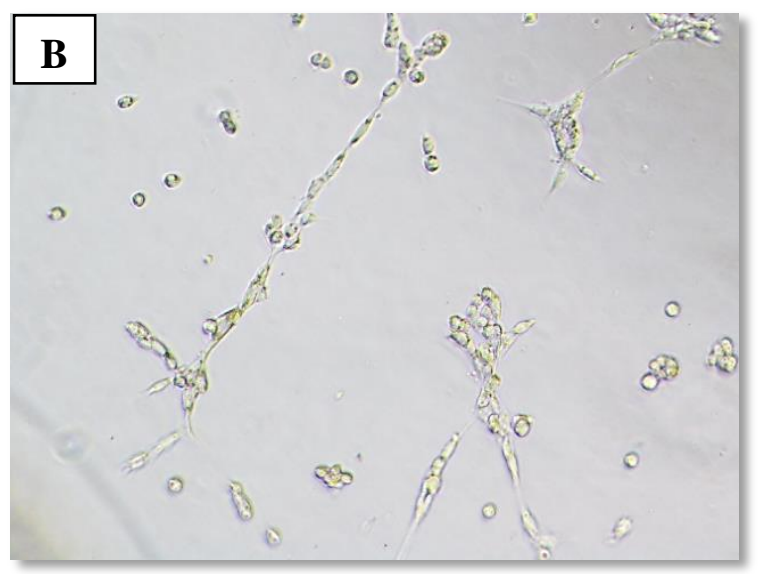

Células endoteliais t.End.1 $\left(1,5 \times 10^{4}\right.$ células/100 $\left.\mu \mathrm{L}\right)$ foram pré-tratadasna ausência (controle) ou presença de CTX $(1,2 \mu \mathrm{g} / \mathrm{mL})$ por 1 hora a $37^{\circ} \mathrm{C}, 5 \%$ de $\mathrm{CO}_{2}$. Durante este período, foram plaqueados $50 \mu \mathrm{L}$ de Matrigel $(9,3 \mathrm{mg} / \mathrm{mL})$ em cada poço da placa de 96 poços e polimerizados por 30 min a $37^{\circ} \mathrm{C}, 5 \%$ de $\mathrm{CO}_{2}$. Após o período de pre-tratamento, as células foram ressuspensas em meio de cultura RPMI 1604 a $2 \%$ SFB e $100 \mu \mathrm{L}$ de t.End.1 foram plaqueados sobre o Matrigel polimerizado, em seguida, incubados por 6 hora de incubação a $37^{\circ} \mathrm{C}, 5 \%$ de $\mathrm{CO}_{2}$. Os resultados estão expressos em número de estruturas tubulares e representam a contagem de 5 campos de 3 amostras distintas de cada grupo. ${ }^{*} \mathrm{p}<0,0001$, por comparação ao grupo controle incubado apenas com meio RPMI 1640 com SFB a $2 \%$. 


\subsection{Efeito da CTX sobre o citoesqueleto de actina e das integrinas $\alpha v$ e $\alpha 2$ em diferentes matrizes}

Neste ensaio foi utilizado anticorpos monoclonais para marcação da $\alpha \mathrm{v}$, principal subunidade para a fibronectina, e $\alpha 2$, principal subunidade para colágeno tipo I e laminina.

A Figura 9A mostra que sob coating de fibronectina, a célula endotelial apresentou corpo celular alongado com citoesqueleto de actina organizado e intensidade da integrina $\alpha \mathrm{v}$ mais evidenciada com distribuição homogênea, demonstrada pela marcação em verde evidenciada pelo anticorpo secundário (círculos), sugerindo conformação de uma célula em processo de migração, uma vez que demonstra presença de protrusões como filopódio e lamelipódio na borda do corpo celular (setas) (Figura 9A). As células previamente tratadas com CTX $(1,2 \mu \mathrm{g} / \mathrm{mL})$ apresentaram menor marcação da integrina (círculos), menor marcação do citoesqueleto de actina e da formação de protrusões como o lamelipódio (setas) (Figura 9B).

Sob coating de colágeno tipo I, houve maior marcação da subunidade $\alpha 2$ (evidenciado em verde) e maior projeção do corpo celular (círculos), além dapresença das protrusões bem como maior marcação das adesões ricas em actina ao redor da célula (setas) (Figura 9C). Células tratadas com CTX $(1,2 \mu \mathrm{g} / \mathrm{mL})$ não apresentaram prolongamentos citoplasmáticos apresentaram menor intensidade da integrina $\alpha 2$, com grande desarranjo do citoesqueleto por conta da desorganização dos filamentos de actina (círculos). Além disso, há marcações pontuais de rodamina (marcação em vermelho) na parte dianteira do corpo celular, sugerindo que houve acúmulo de actina polimerizada no lamelipódio (setas) (Figura 9D).

Em relação ao coating de laminina, as células endoteliais também apresentaram marcação da subunidade $\alpha 2$ homogênea com prolongamentos citoplasmáticos (círculos) e a actina organizada em feixes (setas) (Figura 9E). Já, as células tratadas com CTX, apresentaram diminuição drástica da projeção da célula com marcação da integrina $\alpha 2$ evidente (círculos). Ainda, observa-semaior formação de protrusões, principalmente filopódios e uma tentativa de formação de lamelipódio (setas) (Figura 9F). 
Figura 9 - Efeito da CTX sobre o citoesqueleto de actina e expressão das integrinas av e $\alpha 2$ em componentes de matriz
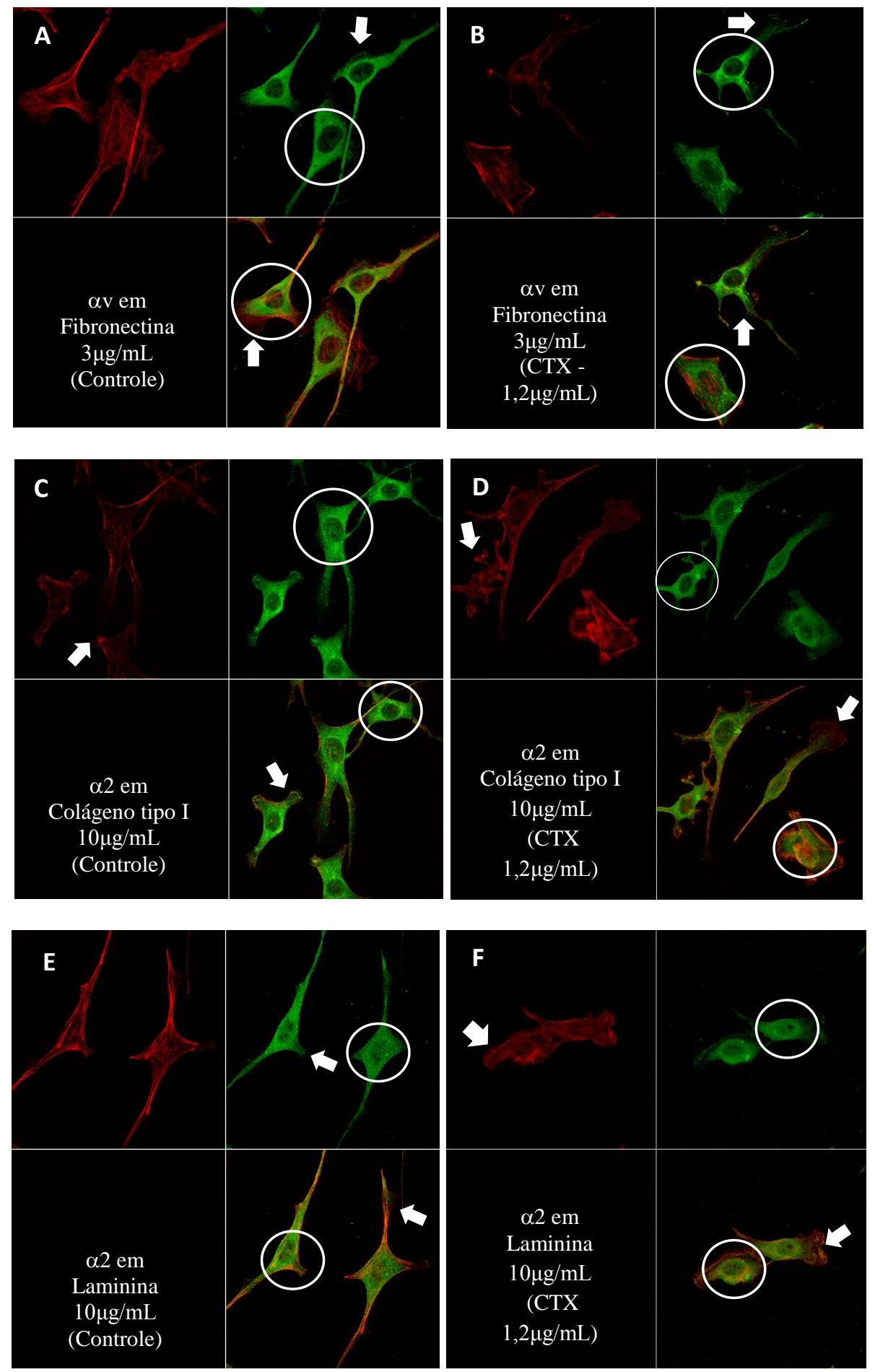

A) Marcação da subunidade de $\alpha v$ (verde) e F-actina (vermelho), das células controles. B) Marcação da subunidade de $\alpha$ v (verde) e F-actina (vermelho), das células tratadas com CTX. C e E) Marcação da subunidade de $\alpha 2$ (verde) e F-actina (vermelho), das células controles. D e F) Marcação da subunidade de $\alpha 2$ (verde) e Factina (vermelho), das células tratadas com CTX. (O) representam a expressão de $\alpha$ v e $\alpha 2$ no corpo celular; $(\boldsymbol{\bullet})$ representam as protrusões. 


\subsection{Efeito da CTX sobre o citoesqueleto de actina e sobre as integrinas $\alpha v$ e $\alpha 2$, em diferentes matrizes, sob estímulo tumoral}

Utilizando novamente a imunofluorescencia, foi investigada a distribuição das subunidades de integrinas, bem como o rearranjo do citoesqueleto de actina de células endoteliais, tratadas ou não com CTX, na presença de meio condicionado de célula tumoral MCF-7. Os resultados obtidos demonstraram que as células endoteliais do grupo controle (tratadas apenas com meio RPMI 1640) apresentaram marcação menos intensa da integrina $\alpha \mathrm{v}$ (círculo), evidenciadas em verde (Figura 10A) e um pouco mais intensa da integrina $\alpha 2$ (círculos) (Figuras 10C e 10E). Em relação ao corpo celular, independentemente da matriz, orearranjo do citoesqueleto foi, de maneira geral, o mesmo, apresentando protrusões de forma regular e organizada (setas).

Já, em células endoteliais tratadas previamente com $1,2 \mu \mathrm{g} / \mathrm{mL}$ de CTX, por 1 hora, observou-se que essas subunidades apresentaram menor ou igual intensidade de marcação, quando comparadas ao grupo controle. Adicionalmente, o citoesqueleto de actina, em coating de fibronectina, apresentoumarcações pontuais visualizadas pela marcação com rodamina (vermelha), evidenciada na borda dos lamelipódios, que são as adesões nascentes (seta) e forte presença de stress fibers (setas) (Figura 10B). Em coating de colágeno e de laminina, observa-se, de maneira similar, a retração do corpo celular a das protrusões citoplasmáticas (setas), alterando assim, a direção da migração (Figura 10D e 10F). 
Figura 10 -Efeito da CTX sobre o citoesqueleto de actina e expressão das integrinas $\alpha \mathrm{v}$ e $\alpha 2$ em componentes de matriz, na presença de meio condicionado de célula tumoral MCF-7
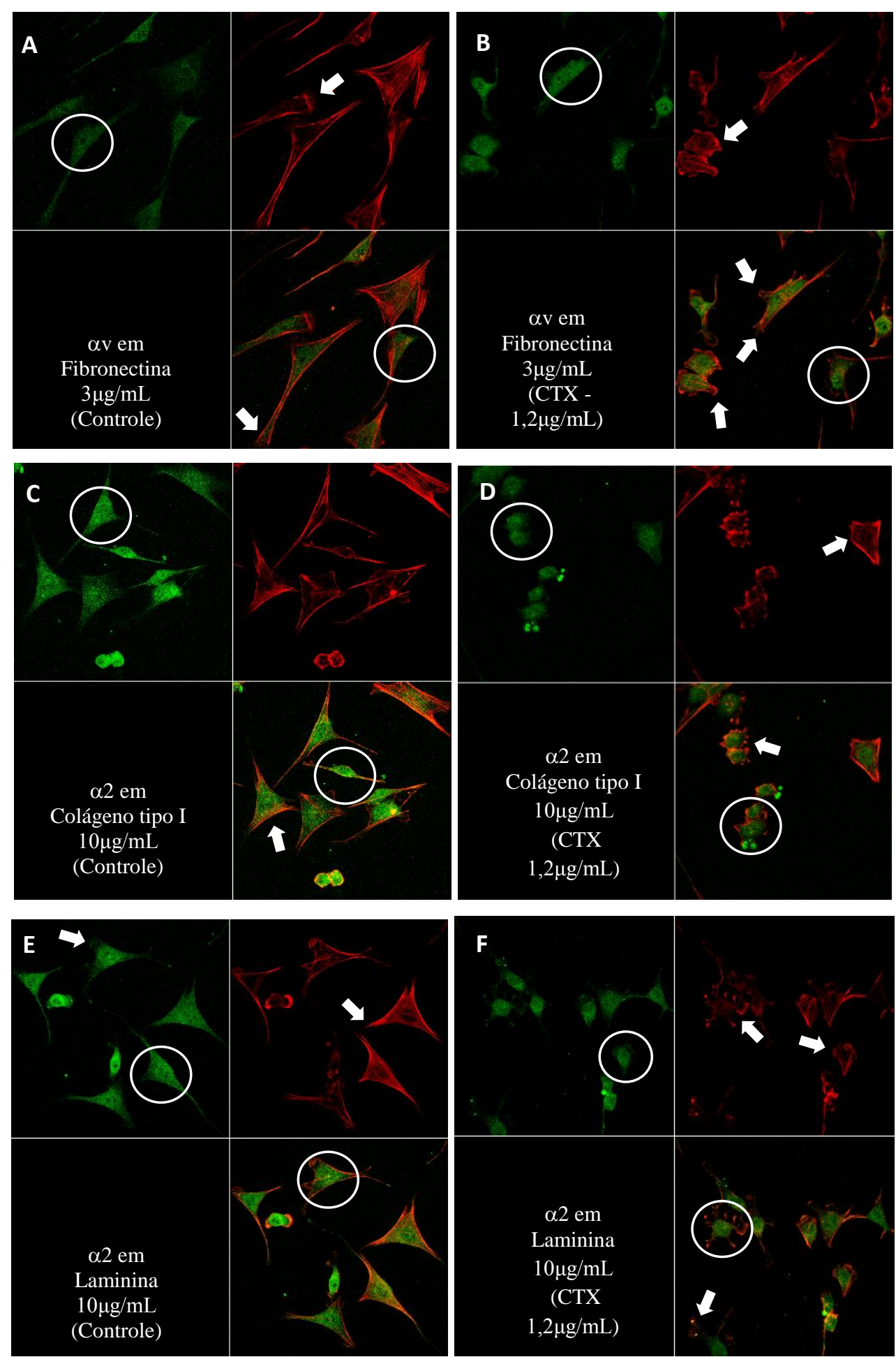

A) Marcação da subunidade de $\alpha$ v (verde) e F-actina (vermelho), das células controles. B) Marcação da subunidade de $\alpha$ v (verde) e F-actina (vermelho), das células tratadas com CTX. C e E) Marcação da subunidade de $\alpha 2$ (verde) e F-actina (vermelho), das células controles. D e F) Marcação da subunidade de $\alpha 2$ (verde) e Factina (vermelho), das células tratadas com CTX. (O) representam a expressão de $\alpha$ v e $\alpha 2$ no corpo celular; ( $)$ representam as protrusões. 


\section{DISCUSSÃO}

Para a sobrevivência de célula tumoral, bem como sua progressão e, consequentemente, invasão aos tecidos mais distantes, a angiogênese é um dos principais fatores que favorece a progressão tumoral, por conta da formação de novos vasos, a partir de vasos pré-existentes fornecendo, assim, nutrientes, oxigênio e fatores de crescimento necessários para a sobrevida da célula tumoral. Este processo envolve a matriz extracelular e as células endoteliais vasculares, as quais respondem a muitos sinais pró e antiangiogênicos (BAZAA et al., 2010; ELICEIRI; CHERESH, 1998; MONTAÑEZ et al., 2002).

Diversos estudos in vivo e in vitro têm demonstrado que a CTX possui atividade antitumoral. Em particular, nosso grupo demonstrou que a esta toxina acarreta importante redução de tumor desenvolvido no coxim plantar ou em flanco de ratos, acompanhada com diminuição da marcação de neovasos nas lâminas histológicas. Baseados nestes fatos, o presente estudo busca caracterizar a ação inibitória da CTX sobre eventos envolvidos no processo de angiogênese, sugerida nestes estudos in vivo (BRIGATTE et al., 2007).

Inicialmente, demonstramos que as células endoteliais tem sua capacidade proliferativa afetada na presença da CTX em diferentes concentrações $(0,6 \mu \mathrm{g} / \mathrm{mL}, 1,2 \mu \mathrm{g} / \mathrm{mL}$ e 2,4 $\mu \mathrm{g} / \mathrm{mL}$ ), após 24 horas de incubação na presença da toxina. É interessante salientar que as concentrações mais responsivas são as intermediárias (entre a menor $[0,15 \mu \mathrm{g} / \mathrm{mL}$ ] e a maior concentração [4,8 $\mu \mathrm{g} / \mathrm{mL}]$ avaliadas). Este perfil já foi observado em outros modelos experimentais, sendo a concentração mediana da curva a mais potente (FAIAD; DELLACASA; SAMPAIO, 2008). Ainda, esta ação inibitória da CTX não é decorrente da perda de viabilidade celular, uma vez que, após $24 \mathrm{~h}$ de incubação as células apresentaram viabilidade superior a 95\%, quando comparado ao controle (dados não mostrados).

Estudos anteriores demonstraram que a CTX é capaz de desencadear suas ações inibitórias sobre a proliferação de células tumorais, após 1 hora de incubação na presença da toxina, seguida de incubações em meio fresco por diferentes períodos (FAIAD, DELLACASA, SAMPAIO, 2008). Baseados nestes fatos foram realizados ensaios com intuito de evidenciar se a incubação de 1 hora na presença das diferentes concentrações da CTX seria capaz de inibir a atividade proliferativa das células endoteliais, após 24 horas de incubação apenas na presença de meio de cultura. Os resultados obtidos demonstraram que, da mesma maneira que observado para a incubação continua na presença da toxina por 24 horas, as células endoteliais tratadas por apenas 1 hora na presença da toxina apresentaram significativa diminuição do número de células nas mesmas concentrações demonstradas para o período de 
24 horas e de magnitude similar. Este resultado demonstra que a ação inibitória sobre a proliferação de células endoteliais é desencadeada logo nos primeiros períodos de incubação (1 hora), mantendo-se por períodos mais prolongados (24 horas), conforme demonstrado para as células tumorais (FAIAD, DELLA-CASA, SAMPAIO, 2008). Esse comportamento também foi evidenciado em estudos realizados pelo grupo, investigando a ação da CTX sobre a atividade secretória de macrófagos durante a progressão tumoral in vitro. Nestes estudos, macrófagos pré-tratados com a CTX $(0,3 \mu \mathrm{g} / \mathrm{mL})$ por 2 horas, apresentam aumento da capacidade secretória, o que acarreta efeito inibitório sobre a proliferação de células tumorais, observada por até 48 horas, no modelo de co-cultura (COSTA et al., 2013).

A proliferação celular depende do grau de adesão entre a célula e seu ligante da matriz extracelular. Assim, em continuidade aos objetivos propostos, foi investigada a ação da CTX sobre a ligação da célula endotelial a diferentes ligantes da matriz extracelular. Neste ensaio, as matrizes utilizadas foram de colágeno tipo I, fibronectina, e laminina. Os dados obtidos demonstraram que as células t.End.1 apresentaram bom grau de adesividade ao colágeno I e a fibronectina, obtendo valores (expresso em número de células) semelhantes aos relatados na literatura (SCHLIE-WOLTER; NGEZAHAYO; CHICHKOV, 2013). Diferentemente do obtido com esses componentes de matriz, a adesividade da t.End.1 foi menor em laminina. Esta menor adesividade da t.End.1 sob esta matriz de laminina pode ser explicada pela sua composição. A laminina é um dos componentes presente na membrana basal de sarcoma de murinos Engelbreth-Holm Swarm (EHS), sendo esta proteína classicamente caracterizada como laminina-1 ou laminina-111 (cadeias $\alpha 1 \beta 1 \gamma 1$ ), e é um ligante não favorável para a ligação da integrina à laminina (Barczyk et al., 2010). Nishiuchi et al (2006) realizou uma análise comparativa da interação entre diferentes integrinas que se ligam à laminina $(\alpha 3 \beta 1$, $\alpha 6 \beta 1, \alpha 7 \beta 1, \alpha 6 \beta 4$ ) e suas isoformas (laminina-1, laminina-2, laminina-3, laminina-4 e laminina-5) e, foi observado que a laminina-1 não apresentou nenhuma interação com as integrinas, porém a laminina-5 foi o ligante preferido para a maioria das integrinas testadas. Sendo assim, a adesão celular depende da isoforma, tanto da integrina quanto da laminina no que se refere à especificidade e afinidade.

Assim, em continuidade, uma vez demonstrado que as concentrações de 0,6 $\mu \mathrm{g} / \mathrm{mL}$, $1,2 \mu \mathrm{g} / \mathrm{mL}$ e $2,4 \mu \mathrm{g} / \mathrm{mL}$ foram as mais importantes para inibir a atividade proliferativa, apenas essas concentrações foram testadas no modelo de adesão, em ensaio de competição. Os resultados demonstraram ação inibitória da CTX na ligação da célula t.End.1 com o colágeno tipo I, em todas as concentrações testadas $(0,6 \mu \mathrm{g} / \mathrm{mL}, 1,2 \mu \mathrm{g} / \mathrm{mL}$ e $2,4 \mu \mathrm{g} / \mathrm{mL})$, quando comparada ao grupo controle. Já, em coating de fibronectina, o efeito inibitório da toxina foi 
evidenciado apenas nas concentrações de $1,2 \mu \mathrm{g} / \mathrm{mL}$ e $2,4 \mu \mathrm{g} / \mathrm{mL}$. Em relação à adesão em laminina, quando as células endoteliais foram incubadas na presença de CTX o efeito inibitório foi promovido somente pela concentração de $1,2 \mu \mathrm{g} / \mathrm{mL}$, quando comparada ao controle. É interessante salientar que a concentração $1,2 \mu \mathrm{g} / \mathrm{mL}$ acarretou sempre o efeito inibitório mais pronunciado, independente da matriz estudada.

Como citado na Introdução, a migração celular é o componente essencial para a progressão tumoral. Assim, foram realizados ensaios de migração utilizando dois modelos in vitro: o wound healing e a quimiotaxia em sistema de transwell. O wound healing é utilizado para avaliar o movimento das células endoteliais no campo vazio de uma ferida artificial criada por uma interrupção na monocamada de células endoteliais. Este ensaio foi realizado utilizando as concentrações de $0,15 \mu \mathrm{g} / \mathrm{mL} ; 0,3 \mu \mathrm{g} / \mathrm{mL}, 0,6 \mu \mathrm{g} / \mathrm{mL}, 1,2 \mu \mathrm{g} / \mathrm{mL}$ e $2,4 \mu \mathrm{g} / \mathrm{mL}$ de CTX, em duas situações: 1) estimuladas com meio de cultura (1\% ou $10 \%$ SFB) ou 2) estimuladas com meio condicionado de células tumorais MCF-7. Na primeira condição, (na presença de meio RPMI 1640 com SFB a 1\%), a CTX, nas concentrações de 1,2 $\mu \mathrm{g} / \mathrm{mL}$ e 2,4 $\mu \mathrm{g} / \mathrm{mL}$, foi capaz de inibir significativamente este evento, a partir da $6^{\mathrm{a}}$ hora, na $12^{\mathrm{a}}$ hora e também na $24^{\mathrm{a}}$ hora, período máximo analisado no modelo de Wound healing, em diferentes estudos (DENKER; BARBER, 2002; DURHAM; HERMAN, 2009; HOTCHKISS et al., 2002). Em todos os tempos avaliados, a concentração de $1,2 \mu \mathrm{g} / \mathrm{mL}$ foi a que acarretou ação inibitória mais marcante. Cabe salientar novamente que a CTX acarreta suas ações mais marcantes em doses medianas, em diferentes células (COSTA et al., 2013; FAIAD; DELLACASA; SAMPAIO, 2008; LIMA et al., 2012). Este fato nos levou a necessidade de estudos farmacocinéticos e de bioinformática para a compreensão da ligação desta toxina em seus alvos celulares. Estes ensaios serão realizados em conjunto com o Laboratório de Bioquimica e Biofísica do IBu e o Departamento de Farmacologia do ICB/USP.

A partir deste resultado, a concentração de $1,2 \mu \mathrm{g} / \mathrm{mL}$ foi a utilizada para o ensaio de wound healing induzido por sobrenadante meio condicionado obtido de células tumorais. Nesta concentração, a CTX inibiu significativamente a migração das células induzidas pelo meio condicionado de célula tumoral MCF-7. Resultados semelhantes foram obtidos no ensaio de quimiotaxia, realizando utilizando apenas a concentração de 1,2 $\mu \mathrm{g} / \mathrm{mL}$. Neste ensaio foi utilizado o modelo de migração celular utilizando a câmara de transwell, onde é possível observar a migração direcional das células endoteliais de uma baixa para uma alta concentração de quimioatrativo (SALCEDO; OPPENHEIM, 2003). Os resultados demonstraram, novamente, que a CTX, na concentração utilizada, inibiu de maneira 
significativa a migração das células endoteliais frente ao estímulo tumoral e frente ao estímulo basal não houve inibição significativa.

É importante salientar que o meio condicionado utilizado no ensaio de migração como fator quimiotático, foi proveniente de uma linhagem tumoral de mama humana (MCF-7), com característica altamente invasiva, decorrentes da sua capacidade de secretar diversos fatores de crescimento, incluindo as quimiocinas, que são citocinas pró-inflamatórias moduladoras do processo angiogênico (ROMAGNANI et al., 2004). Neste sentido, a literatura demonstra que as células de diferentes tumores mamários secretam quimiocinas com potencial angiogênico, como a CXCL8 (Interleucina-8), ligante dos receptores CXCR1 e CXCR2, moderadamente expressos nas células endoteliais (SINGH; SADANANDAM; SINGH, 2007) e a quimiocina CXCL12 (Fator-1 derivado de células estromais ou SDF-1), a mais estudada na angiogênese tumoral, por induzir a migração e proliferação das células endoteliais, formação de tubos, bem como a produção de VEGF (SINGH; SADANANDAM; SINGH, 2007; SINGH et al., 2013). De acordo com Salcedo e Oppenheim (2003), o CXCR4 é o receptor mais expresso nas células endoteliais que interage com a quimiocina CXCL12, o mais potente quimioatrativo entre todas as quimiocinas da família CXC para as células endoteliais. Recentemente, foi descrito outro receptor, o CXCR7, que também interage com a quimiocina CXCL12, expresso principalmente pelas células endoteliais associadas ao microambiente tumoral (SINGH et al., 2013). Uma vez observada importante ação inibitória da CTX sobre a migração das células endoteliais, particularmente frente ao estímulo quimiotático proveniente do meio de cultura obtido de células tumorais, pode-se sugerir que a CTX tenha uma ação sobre os receptores ligantes de quimiocinas das células endoteliais frente ao estímulo tumoral. Esta ação estaria de acordo com a atividade anti-inflamatória descrita para esta toxina (NUNES et al., 2010). Esta hipótese será investigada.

A formação de estruturas do tipo capilar é a etapa essencial do processo de angiogênese. Para estudar a angiogênese in vitro, foi utilizado o Matrigel, uma membrana basal reconstituída, que permite rápida formação dessas estruturas em um sistema 3D, sendo um método simples e facilmente quantificável (ARNAOUTOVA et al., 2009; BAZZA et al., 2010). Inicialmente, obteve-se uma houve rápida formação de uma rede de capilares após 2 horas de incubação no grupo controle (dados não mostrados). Ainda no grupo controle, a partir da $6^{\mathrm{a}}$ hora, a rede se estabilizou formando estruturas alongadas com intensa comunicação célula-célula. Esta formação de estruturas do tipo capilar, etapa essencial do processo de angiogênese, também foi afetada na presença da CTX, alterando a morfologia da célula endotelial por impedir a sua projeção ao matrigel, uma membrana basal reconstituída, 
que permite rápida formação dessas estruturas em um sistema $3 \mathrm{D}$, sendo um método simples e facilmente quantificável (ARNAOUTOVA et al., 2009; BAZZA et al., 2010). É sugestivo que o Matrigel propicia condições similares ao observado em microambiente tumoral, uma vez que é proveniente do sarcoma de murinos EHS, fornecendo assim, rápida formação de estruturas tubulares, conforme observado em nosso estudo. Além disso, os resultados deste ensaio corroboram com os dados obtidos nos ensaios de adesão e de migração celular, que nos permite sugerir que a CTX afeta os principais processos que dependem diretamente da reoganização do citoesqueleto.

O citoesqueleto de actina está diretamente relacionado com o comportamento adesivo e migratório das células endoteliais, os quais estão acorados a integrinas, moléculas de adesão com comunicação bidirecional permitindo a interação entre as células e os componentes matriz extracelular (WEIS; CHERESH, 2011), permitindo a reorganização do citoesqueleto de actina e consequentemente a migração da célula, porporcionando progresso no processo de angiogênese.

Como relatado na Literatura, a integrina $\alpha v \beta 3$ é capaz de se ligar a diferentes componentesde matriz, incluindo a fibronectina e esta integrina está diretamente relacionada com a angiogênese tumoral (BAZAA et al., 2010; HOOD; CHERESH, 2002), além de ser expressa na superfície das células endoteliais (ARRUAND-LIONS et al., 2004; DAVIS; SENGER, 2005). Além disso, as principais integrinas responsáveis pela interação entre a célula endotelial e o colágeno são as integrinas $\alpha 1 \beta 1$, reconhecendo preferencialmente o colágeno tipo IV, e $\alpha 2 \beta 1$ que se liga principalmente ao colágeno tipo I (ARLINGHAUS et al., 2013) e à laminina (LANGUINO et al., 1989), provocando após sua adesão, mudanças na forma destas células para promover a migração celular (DAVIS; SENGER, 2005).

Baseado nestes fatos, por meio do ensaio de imunofluorescência, foi observado que a distribuição das subunidades de integrinas $\alpha v$ (em coating de fibronectina) e $\alpha 2$ (em coating de colágeno tipo I e laminina) foi alterada nas células endoteliais tratadas com CTX, comparada com o controle. Consequentemente, esta diminuição pode ter desencadeado alterações no citoesqueleto de actina, promovendo desarranjo na projeção da célula sob coating de laminina, desorganização e diminuição das stress fibers sob coating de colágeno e fibronectina, respectivamente, comprometendo a contração do citoesqueleto. Ainda, observou-se acúmulos pontuais de actina pelo no lameipódio em coating de colágeno e fibronctina. Sendo assim, essas modulações do citoesqueleto de actina e das protrusões promovidas pela presença de CTX, possam ter sidodecorrentes de diminuição da sinalização intracelular relacionada a migração (RIDLEY et al., 2003) e possívelmente,à diminuição da 
expressão das subunidades de integrinas e, em consequencia, baixa adesividade entre a célula endotelial e o componente de matriz, impedindo, assim, a geração de força de tração o suficiente para uma migração eficiente (HOOD; CHERESH, 2002).

Sob estímulo tumoral, as subunidades de integrinas av e $\alpha 2$, na presença de CTX, acarretaram inibição da projeção das células endoteliais, apresentando formato arredondado e formação de protrusões ao seu redor com marcação de actina nessas adesões imaturas. Interessantemente, a distribuição da subunidade $\alpha 2$ em coating de colágeno e laminina, apresentou menor intensidade acompanhada de maior retração do corpo celular, sem formação regular de protrusões, corroborando com os dados obtidos no ensaio de wound healing com estímulo tumoral, onde acarretou $81 \%$ de inibição da migração. De acordo com o estudo realizado por Zhang et al. (2008), foi demonstrado que em condições fisiopatológicas, a ausência da integrina $\alpha 2 \beta 1$ em camundongos $\alpha 2$-null levou ao aumento da expressão do VEGF1 e aumento da angiogênese tumoral. Baseado nesses fatos e nos resultados obtidos, podemos sugerir fortemente que a CTX é capaz de inibir a expressão da integrina $\alpha 2 \beta 1$.

As características observadas no ensaio de imunofluorescência como a morfologia, o citoesqueleto e a extensão da célula estão fortemente correlacionadas com a proteína quinase FAK por estimular a polimerização da actina e a formação de filopódia de maneira dependente de Cdc42 e independente de Rho (SCHLIE-WOLTER; NGEZAHAYO; CHICHKOV, 2013). Estudos anteriores realizados pelo grupo demonstraram que a CTX é capaz de inibir a expressão das Rho GTPases tanto em macrófagos, inibindo a translocação de RhoA e Rac1, interferindo com a eficiência do citoesqueleto na captação das partículas a serem fagocitadas (SAMPAIO et al., 2006b). Ainda, em células tumorais da linhagem LLC WRC 256, a CTX foi capaz de inibir RhoA e quinase FAK (FAIAD, DELLA-CASA, SAMPAIO, 2008), comprometendo a polimerização dos filamentos de actina dessas células envolvidas também com a proliferação e adesão da célula tumoral. Ensaios preliminares evidenciaram a ação inibitória da CTX sobre a expressão das subunidades $\alpha 2$, $\alpha \mathrm{v}$ das integrinas e sobre as quinases ERK e FAK em células t.End.1 (KATO, ZAMBELLI, SAMPAIO, comunicação pessoal) ${ }^{1}$.

Desse modo, sugerimos fortemente que a CTX exerce sua ação inibitória sobre a expressão das integrinas $\alpha v \beta 3$ e $\alpha 2 \beta 1$ e, consequentemente, interferindo com a fosforilação das quinases ERK e FAK, além das Rho GTPases, uma vez que essas proteínas efetoras são ativadas, e como efeito, irão regular a proliferação celular (BRYAN; D’AMORE, 2007), entre

\footnotetext{
${ }^{1}$ Informação obtida por Kato, Zambelli e Sampaio, no Laboratório Especial de Dor e Sinalização. São Paulo, março 2014.
} 
outros processos celulares como a migração e invasão (VEGA; RIDLEY, 2008). Entretanto, estudos estão sendo realizados para comprovar essa hipótese.

Em conjunto, os resultados obtidos neste estudo caracterizam, pela primeira vez, a ação inibitória da CTX sobre os principais eventos envolvidos com a angiogênese, e pode, portanto, contribuir para novas perspectivas no desenvolvimento de um novo desenho de substâncias com propriedades terapêuticas no controle de neoplasias, além de ampliar o conhecimento sobre os mecanismos envolvidos com as ações descritas para esta toxina. 


\section{CONCLUSÃO}

Os dados obtidos neste presente estudo nos permitem concluir que a CTX inibe os principais eventos envolvidos com a angiogênese, tais como adesão, proliferação, migração das células endoteliais, diminuindo a formação de tubos. Ainda, a CTX inibiu a distribuição das subunidades $\alpha_{\mathrm{v}}$ e $\alpha_{2}$ de integrinas, com consequente mudança na polimerização do citoesqueleto de actina destas células. Particularmente, o efeito inibitório desta toxina foi mais pronunciado frente ao estímulo tumoral. Esta inibição sobre esses eventos não foi decorrente da perda de viabilidade celular. 


\section{REFERÊNCIAS}

AIRD, S. D. et al. A complete amino acid sequence for the basic subunit of crotoxin. Arch. Biochem.Biophys., v. 249, n. 2, p. 296-300, 1986.

AIRD, S D. et al. The amino acid sequence of the acidic subunit B-chain of crotoxin. Biochim. Biophys. Acta., v. 1040, n. 2, p. 217-224, 1990.

ALEXANDER, G. et al. Gyroxin, a toxin from the venom of Crotalus durissus terrificus, is a trombin-like enzyme. Toxicon, v. 26, p. 953-960, 1988.

ALEXANDER, S. et al. Dynamic imaging of cancer growth and invasion: a modified skinfold chamber model. Histochem. Cell Biol., v. 130, p. 1147-1154, 2008.

AMARAL, C. F.; MAGALHÃES, R. A.; DE REZENDE, N. A. Respiratory involvement secondary to crotalid ophidian bite (Crotalus durissus). Rev. Inst. Med. Trop. Sao Paulo, v. 33, p. 251-255. 1991.

AMORIM, M. F.; DE MELLO, R. F.; SALIBA, F. Envenenamento botrópico e crotálico. Mem. Inst. Butantan, v. 23, p. 108, 1951.

ARLINGHAUS, F. T. et al. Identification of $\alpha 2 \beta 1$ integrin inhibitor VP-I with anti-platelet properties in the venom of Vipera palaestinae. Toxicon, v. 64, p. 96-105, 2011.

ARNAOUTOVA, I. et al. The endothelial cell tube formation assay on basement membrane turns 20: state of the science and the art. Angiogenesis, v. 12, p. 267-274, 2009.

ARRAUND-LIONS, M. et al. Haemangiomas are formed by cells expressing high levels of $\alpha v \beta 3$ integrin and lacking acetylated LDL uptake. J. Pathol., v. 203, p. 700-709, 2004.

AVRAAMIDES, C. J.; GARMY-SUSINI, B.; VARNER, J. A. Integrins in angiogenesis and lymphangiogenesis. Nat. Rev. Cancer, v. 8, p. 604-617, 2008.

AZEVEDO-MARQUES, M. M. et al. Myonecrosis myoglobinuria and acute renal failure indice by South American rattlesnake (Crotalus durissus terrificus) envenomation in Brazil. Toxicon, v. 23, p. 633-636, 1985.

AZEVEDO-MARQUES, M. M.; CUPO, P.; HERING, S. E. Evidence that Crotalus durissus terrificus (South American rattlesnake) envenometion in human causes myolysis rather than hemolysis. Toxicon, v. 11, p. 1163-1168, 1987.

BAILEY, P.; WILCE, J. Venom as a source of useful biologically active molecules. Emerg. Med. (Fremantle), v. 13, p. 28-36, 2001.

BARCZYK, M.; CARRACEDO, S.; GULlBERG, D. Integrins. Cell Tissue Res., v. 339, p. 269-280, 2010.

*De acordo com:

ASSOCIAÇÃO BRASILEIRA DE NORMAS TÉCNICAS. NBR 6023: informação e documentação: referências: elaboração. Rio de Janeiro, 2002. 
BAYLESS, K. J.; DAVIS, G. E. The Cdc42 and Rac1 GTPases are required for capillary lumen formation in three-dimensional extracellular matrices. J. Cell Sci., v. 115, p. 11231136, 2002.

BAZAA, A. et al. MVL-PLA2, a Snake Venom Phospholipase A2, Inhibits Angiogenesis through an Increase in Microtubule Dynamics and Disorganization of Focal Adhesions. PLoS One, v. 5, p. e10124, 2010.

BERGERS, G. et al. Matrix metalloproteinase-9 triggers the angiogenic switch during carcinogenesis. Nat. Cell Biol., v. 2, p. 737-744, 2000.

BON, C. et al. Crotoxin halfcentury of investigations on a phospholipase A2 neurotoxin. Acta Physiol. Pharmacol. Latino-Am., v. 39, p. 439-448, 1989.

BORASCHI, D. et al.Endothelial cells express the interleukin-1 receptor type 1. Blood, v. 78, n. 5 , p. $1262-1267,1991$.

BRAZIL, V. Do emprego da peçonha em terapêutica. An. Paul. Med. Cir, v. 60, p. 398-408, 1950.

BRIGATTE, P. et al. Walker 256 tumor-bearing rats as a model to study cancer pain. J. Pain, v. 8, p. 412-421, 2007.

BROOS, K. et al. Blood platelet biochemistry. Thrombosis Research, v. 129, n. 3, p. 245249, 2012.

BRYAN, B. A.; D'AMORE, P. A. What tangled webs they weave: Rho-GTPase control of angiogenesis. Cell Mol. Life Sci, v. 64, p. 2053-2065, 2007.

CARDOSO, D. F.; MOTA, I. Effect of Crotalus venom on the humoral ans celular immune response. Toxicon, v. 4, p. 607-612, 1997.

CARDOSO, D. F. et al. Role of crotoxin, a phospholipase A2 isolated from Crotalus durissus terrificus snake venom, on inflammatory and immune reactions. Mediators of inflammation, v. 10, p. 125-133, 2001.

CEZAR-DE-MELLO, P. F. T. et al. ATL-1, an analogue of aspirin-triggered lipoxin A4, is a potent inhibitor of several steps in angiogêneses induced by vascular endothelial growth factor. British Journal of Pharmacology, v. 153, p. 956-965, 2008.

CHAN, P. C. et al. Crosstalk between hepatocyte growth factor and integrin signaling pathways. J. Biomed. Sci., v. 13, n. 2, p. 215-223, 2006.

CHOUMET, V. et al. Struture and function relationship of crotoxin, a heterodimeric neurotoxic phospholipase A2 from the venom of a South-American rattlesnake.Adv. Exp. Med. Biol., v.391, p. 197-202, 1996.

COSTA, E. S. et al. Effect of Crotoxin, the main toxin of the rattlesnake C.d. terrificus venom, on secretory activity of peritoneal macrophages during tumor progression. Basic \& 
Clinical Pharmacology \& Toxicology. Official Journal of Worls Pharma, v. 107, p. 2729, 2010, Suppl. 1. ISSN: 1742-7835. (Abstracts - World Congress Of Basic And Clinical Pharmacology, 16., 2010).

COSTA, E. S. et al. Involvement of formyl peptide receptors in the stimulatory effect of crotoxin on macrophages co-cultivated with tumour cells. Toxicon, v. 74, p. 167-178, 2013.

CUENOD, C. A. et al. Tumor angiogenesis: pathophysiology and implications for contrastenhanced MRI and CT assessment. Abdom Imaging, v. 31, p. 188-193, 2006.

CUKIERMAN, E.; PANKOV, R.; YAMADA, K. M. Cell interactions with three-dimensional matrices. Curr. Opin. Cell Biol., v. 14, n. 5, p. 633-639, 2002.

CUPO, P.; AZEVEDO-MARQUES, M. M.; HERING, S. E. Clinical and laboratory features of South American rattlesnake (Crotalus durissus terrificus) envenomation in children. Trans. R. Soc. Trop. Med. Hyg., v. 82, p. 924-929, 1988.

CURY, Y.; PICOLO, G. Animal toxins as analgesics--an overview. Drug News Perspect., v. 19, p. 381-392, 2006.

CZUCHRA, A. et al. Cdc42 is not essential for filopodium formation, directed migration, cell polarization, and mitosis in fibroblastoid cells. Mol. Biol. Cell, v. 16, p. 4473-4484, 2005.

DASS, C. R.; TRAN, T. M. N.; CHOONG, P. F. M. Angiogenesis inhibitors and the need for anti-angiogenic therapeutics. J. Dent. Res., v. 86, p. 927-936, 2007.

DAVIS, G, E.; SENGER, D. R. Endothelial Extracellular Matrix: Biosynthesis, Remodeling, and Functions During Vascular Morphogenesis and Neovessel Stabilization.Circ. Res., v. 97, p. 1093-1107, 2005.

DELANO, W. L. The PyMOL Molecular Graphics System.Delano Scientific LLC, San Carlos. Disponível em: <http://www.pymol.org>. Acesso em: 12 ago. 2013.

DÉLOT, E.; BON, C. Model for the interaction of crotoxin, a phospholipase A2 neurotoxin, with presynaptic membranes. Biochemistry, v. 32, p. 10708-19713, 1993.

DENKER, S. P.; BARBER, D. L. Cell migration requires both ion translocation and cytoskeletal anchoring by the NA-H exchanger NHE1. J. Cell Biol., v. 159, p. 1087-1096, 2002.

DURHAM, J. T.; HERMAN, I. M. Inhibition of angiogenesis in vitro: a central role for betaactin dependent cytoskeletal remodeling. Microvasc. Res., v. 77, n. 3, p. 281-288, 2003.

ECKES, B. et al., Mechanical tension and integrin alpha 2 beta 1 regulate fibroblast functions. J. Investig. Dermatol. Symp. Proc., v. 11, n. 1, p. 66-72, 2006.

EHRMANN, R. L.; GEY, G. O.The growth of cells on a transparent gel of reconstituted rattail collagen. J. Natl. Cancer Inst., v. 16, p. 1375-1403, 1956. 
ELSDALE, T.; BARD, J. Collagen substrata for studies on cell behavior. J. Cell Biol., v. 54, n. 3, p. 626-637, 1972.

ELICIERI, B. P.; CHERESH, D. A. The Role of av Integrins during Angiogenesis. Molecular Medicine, v. 4, p. 741-750, 1998.

EVEN-RAM, S.; YAMADA, K. M. Cell migration in 3D matrix. Curr. Opin. Cell Biol., v. 17, n. 5, p. 524-532, 2005.

FAIAD, O. J.; DELLA-CASA, M. S.; SAMPAIO, S. C. Lipoxin A4 contributes to inhibitory effect of Crotoxin on growth of Walker 256 tumor. In: ANNUAL SCIENTIFIC MEETING, 10., 2008, São Paulo. Anais... December 2008. p. 65, seção 8.04.

FIERRO, I. M. Angiogenesis and lipoxins. Prostaglandins Leukot Essent Fatty Acids, v. 73, n. 3-4, p. 271-275, 2005.

FOLKMAN, J. Angiogenesis in cancer, vascular, rheumatoid and other disease. Nat. Med., v. 1, p. 27-31, 1995.

FOLKMAN, J. Angiogenesis: an organizing principle for drug discovery? Nat. Rev. Drug Discov., v. 6, p. 273-286, 2007.

FORM, D. M.; PRATT, B. M.; MADRI, J. A. Endothelial cell proliferation during angiogenesis. Lab. Invest., v. 55, p. 521-530, 1986.

FRAENKEL-CONRAT, H.; SINGER, B. Fractionation and composition of crotoxin. Archs. Biochem., v. 60, p. 64-73, 1956.

FRANCIS, M. E.; URIEL, S.; BREY, E. M. Endothelialcell-matrix interactions in neovascularization. Tissue Eng. Part B Rev., v. 14, n. 1, p. 19-32, 2008.

FRIEDERICH, C.; TU, A. T. Role of metals in snake venoms of hemorrhage, esterase and proteolytic activities. Biochem. Pharmacol., v. 20, p. 1549-1556, 1971.

FRIEDL, P.; BRÖCKER, E. B. T cell migration in three-dimensional extracellular matrix: guidance by polarity and sensations. Dev. Immunol., v. 7, n. 2-4, p. 249-266, 2000.

GARRIDO, T. et al. Endothelial cell differentiation into capillary-like structures in response to tumour cell conditioned medium: a modified chemotaxis chamber assay. Br. J. Cancer, v. 71, n. 4, p. 770-775, 1995.

GIALELI, C.; THEOCHARIS, A. D.; KARAMANOS, N. K. Roles of matrix metalloproteinases in cancer progression and their pharmacological targeting. FEBS J., v. 278, n. 1, p. 16-27, 2011.

GOPALAKRISHNAKONE, $\mathrm{P}$. et al. Cellular and mitocondrial changes induced in the structure of murine skeletal muscle by crotoxin, a neurotoxic phospholipase A2 complex. Toxicon, v. 22, p. 85-98, 1984. 
HERBRAND, U.; AHMADIAN, M. R. p190-RhoGAP as an integral component of the Tiam1/Rac1-induced downregulation of Rho. Biol. Chem., v. 387, p. 311-317, 2006.

HOOD, J. D.; CHERESH, D. A. Role of integrins in cell invasion and migration. Nat. Ver. Cancer., v. 2, n. 2, p. 91-100, 2002.

HOTCHKISS, K. A. et al. Inhibition of endothelial cell function in vitro and angiogenesis in vivo by docetaxel (Taxotere): association with impaired repositioning of the microtubule organizing center. Mol. Cancer Ther., v. 1, n. 13, p. 1191-1200, 2002.

IWANAGA, S.; SUZUKI, T. Enzymes in snake venoms: In: LEE, C. Y. (Ed.). Handbook of Experimental Pharmacology, v. 52, p. 61-158, 1979.

JAFFE, E. A. Cell biology of endothelial cells. Hum. Pathol., v. 18, p. 234-239, 1987.

JAYO, A.; PARSONS, M. Imaging of cell adhesion events in 3D matrix environments. Eur. J. Cell Biol., v. 91, n. 11-12, p. 824-833, 2012.

KUBOTA, Y. et al. Role of laminin and basement membrane in the morphological differentiation of human endothelial cells into capillary-like structures. J. Cell Biol., v. 107, n. 4, p. 1589-1598, 1988.

LACAUD, G.; KELLER, G.; KOUSKOFF, V. Tracking mesoderm formation and specification to the hemangioblast in vitro. Trends Cardiovasc.Med., v. 14, n. 8, p. 314-317, 2004.

LAMALICE, L.; LE BOEUF, F.; HOUT, J. Endothelial Cell Migration During Angiogenesis. Circ. Res., v. 100, p. 782-794. 2007.

LAMMERMANN, T. et al. Rapid leukocyte migration by integrin independent flowing and squeezing. Nature, v. 435, p. 51-55, 2008.

LANDUCCI, E. C. et al. Effect of crotapotin and heparin on the rat paw edema induced by different secretory phospholipases A2. Toxicon, v. 38, p. 199-208, 2000.

LANDUCCI, E. C. et al. Inhibition of carrageenininduced rat paw oedema by crotapotin, a polypeptide complexed with phospholipase A2. Br. J. Pharmacol., v. 114, p. 578-583, 1995.

LANGUINO, L. R. et al. Endothelial cells use alpha 2 beta 1 integrin as a laminin receptor. J. Cell Biol., v. 109, n.5, p.2455-2462, 1989.

LEAVESLEY, D. I.; FERGUSON, G. D.; WAYNER, E. A.; CHERESH, D. A. Requirement of the integrin $\beta 3$ subunit for carcinoma cell spreading or migration on vitronectin and fibrinogen. J. Cell Biology., v. 17, p. 1101-1107, 1992.

LEE, C. Y. Snake venoms. In: Handbook of experimental pharmacology. Berlin, Spring-Verlag, 1979. v. 52.

LEWIS, R. J.; GARCIA, M. L. Therapeutic potential of venom peptides. Nat. Rev. Drug Discov., v. 2, n. 10, p. 790-802, 2003. 
LIMA, T. S. et al. Crotoxin, a rattlesnake toxin, induces a long-lasting inhibitory effect on phagocytosis by neutrophils. Exp. Biol. Med., v. 10, p. 1219-1230, 2012.

MARGADANT, C.; MONSUUR, H. N.; NORMAN, J. C.; SONNENBERG, A. Mechanisms of integrin activation and trafficking. Curr.Opin. Cell Biol., v. 23, n. 5, p. 607-614, 2011.

MARKLAND, F. S. Snake venoms and the hemostatic system. Toxicon, v. 36, p. 1749-1800, 1998.

MARTINS, G. G.; KOLEGA, J. Endothelial cell protrusion and migration in threedimensional collagen matrices. Cell Motil.Cytoskeleton., v. 63, n. 2, p, 101-115, 2006.

MCMAHON, B.; GODSON, C. Lipoxins: endogenous regulators of inflammation. Am. J. Physiol. Renal Physiol., v. 6, n. 2, p. 189-201, 2004.

MEEROVITCH, K. et al. A novel RGD antagonist that targets both alphavbeta3 and alpha5beta1 induces apoptosis of angiogenic endothelial cells on type I collagen. Vascul Pharmacol., v. 40, n. 2, p. 77-89, 2003.

MELO, F. H. M.; JUNQUEIRA, M. S.; CHAMMAS, R. Mecanismos de Invasão e Metástases. In: BRENTANI, M. M.; KOWALSKI, L. P.; COELHO, F. R. G. Bases da Oncologia. 2 ed. São Paulo: Editora Marina e Tedmedd Editora, 2003. p. 201-226.

MENDES-DA-CRUZ, D. A.; SMANIOTTO, S.; KELLER, A. C.; DARDENNE, M.; SAVINO, W. Multivectorial abnormal cell migration in NOD mouse thymus. J. Immunol., v. 180, p. 4639-4647, 2008.

MICHEL, J. B. Role of endothelial nitric oxide in the regulation of the vasomotor system Pathol. Biol., v. 46, n. 3, p. 181-189, 1998.

MONTAÑEZ, E. et al. Comparative study of tube assembly in three-dimensional collagen matriz and on Matrigel coats. Angiogenesis, v. 5, p. 167-172, 2002.

MORGAN, D. M. Measurement of polyamine transport. Adherent cells. Methods Mol. Biol., v. 79, p. 139-147, 1998.

NAHAS, L.; MACFARLANE, R. G.; DENSON, K. W. A. Study of the Coagulant Action of Eight Snake Venoms. Thromb. Diath. Haemorrh., v. 31, n. 12, p. 355-367, 1964.

NISATO, R. E. et al. Alpha $\mathrm{v}$ beta 3 and alpha $\mathrm{v}$ beta 5 integrin antagonists inhibit angiogenesis in vitro. Angiogenesis, v. 6, n. 2, p. 105-119, 2003.

NISHIUCHI, R. et al. Ligand-binding specificities of laminin-binding integrins: a comprehensive survey of laminin-integrin interactions using recombinant alpha3beta1, alpha6beta1, alpha7beta1 and alpha6beta4 integrins. Matrix Biol., v. 25, n. 3, p. 189-197, 2006.

NOBES, C. D.; HALL, A. Rho GTPases control polarity, protrusion, and adhesion during cell movement. J. Cell Biol., v. 22, p. 1235-1244, 1999. 
NOGUERA, R. et al. Extracellular matrix, biotensegrity and tumor microenvironment. An update and overview. Histol. Histopathol., v. 27, n. 6, p. 693-705, 2012.

NTAYI, C. et al. Cumulative influence of matrix metalloproteinase- 1 and -2 in the migration of melanoma cells within three-dimensional type I collagen lattices. Exp. Cell Res., v. 270, p. 110-118, 2001.

NUNES F. P. et al. Long-lasting anti-inflammatory properties of Crotalus durissus terrificus snake venom in mice. Toxicon, v. 49, n. 8, p. 1090-1098, 2007.

NUNES, F. P. et al. Crotoxin is responsible for the long-lasting anti-inflammatory effect of Crotalus durissus terrificus snake venom: involvement of formyl peptide receptors. Toxicon, v. 55, n. 6, p. 1100-1106, 2010.

PARK, H. Y. et al. Potential role of leptin in angiogenesis: leptin induces endothelial cell proliferation and expression of matrix metalloproteinases in vivo and in vitro. Exp. Mol. Med., v. 33, n. 2, p. 95-102, 2001.

PARSONS, J. T.; HORWITZ, A. R.; SCHWARTZ, M.A. Cell adhesion: integrating cytoskeletal dynamics and cellular tension. Nat. Rev. Mol. Cell Biol., v. 11, n. 9, p. 633-643, 2010.

RAMOS F. W. S. Efeitos do hormônio do crescimento sobre as células endoteliais tímicas. 2008. 68 f. Dissertação (Mestrado em Ciências da Saúde) - Instituto de Ciências Biológicas da Saúde, Universidade Federal de Alagoas, Alagoas, 2008.

RANGEL-SANTOS, A. et al. A comparative study of biological activities of crotoxin and CB fraction of venoms from Crotalus durissus terrificus, Crotalus durissus cascavella and Crotalus durissus collilineatus. Toxicon, v. 43, n. 7, p. 801-810, 2004.

RIDLEY, A. J.; HALL, A. The small GTPbinding protein rho regulates the assembly of focal adhesions and actin stress fibers in response to growth factors. Cell, v. 70, p. 389-399, 1992.

RIDLEY, A. J.; PATERSON, H. F.; JOHNSTON, C. L. DIEKMANN, D.; HALL A. The small GTP-binding protein rac regulates growth factor-induced membrane ruffling. Cell, v. 70, p. 401-410, 1992.

RIDLEY, A. J. Cell migration: integrating signals from front to back. Science, v. 302, n. 5651, p. 1704-1709, 2003.

RIENTO, K.; RIDLEY, A. J. Rocks: multifunctional kinases in cell behaviour. Nature Rev. Mol. Cell Biol., v. 4, p. 446, 2003.

ROSARIO, T.; DESIMONE, D. W. The extracellular matrix in development and morphogenesis: a dynamic view. Dev. Biol., v. 341, n. 1, p. 126-140, 2010.

ROMAGNANI, P. et al. CXC chemokines: the regulatory link between inflammation and angiogenesis. Trends Immunol., v. 25, n. 4, p. 201-209, 2004. 
ROSENFELD, G. Symptomathology, Pathology and Treatment of snakes bites in South America. In: BÜCHERL, W.; BUCKLEY, E. (Ed.). Venomous animals and their venoms. New York: Academic Press, 1971. p. 345-384.

SACHARIDOU, A. et al. Endothelial lumen signaling complexes control 3D matrix-specific tubulogenesis through interdependent Cdc42- and MT1-MMP-mediated events. Blood, v. 115 , n. 25, p. 5259-5269, 2010.

SAHAI, E.; MARSHALL, C. J. Rho-GTPases and cancer.Nat. Rev. Cancer, v. 2, n. 2, p.133$142,2002$.

SALCEDO, R.; OPPENHEIM, J. J. Role of Chemokines in Angiogenesis: CXCL12/SDF-1 and CXCR4 Interaction, a Key Regulator of Endothelial Cell Responses. Microcirculation, v. 10, p. 359-370, 2003.

SAMPAIO, S. C. et al. Contribution of crotoxin for the inhibitory effect of Crotalus durissus terrificus snake venom on macrophage function.Toxicon, v. 41, p. 899-907, 2003.

SAMPAIO, S. C. et al. Crotalus durissus terrificus snake venom regulates macrophage metabolism and function. J. Leukoc. Biol., v. 70, p. 551-558, 2001.

SAMPAIO, S. C. et al. Crotoxin induces actin reorganization and inhibits tyrosine phosphorylation and activity of small GTPases in rat macrophages. Toxicon, v. 47, n. 8, p. 909-919, 2006b.

SAMPAIO, S. C. et al. Crotoxin: novel activities for a classic beta-neurotoxin. Toxicon, v. 55, n. 6, p. 1045-1060, 2010.

SAMPAIO, S. C. et al. Inhibitory effect of phospholipase $A(2)$ isolated from Crotalus durissus terrificus venom on macrophage function. Toxicon, v. 45, n. 5, p. 671-676, 2005.

SAMPAIO, S. C. et al. Lipoxygenase-derived eicosanoids are involved in the inhibitory effect of Crotalus durissus terrificus venom or crotoxin on rat macrophage phagocytosis. Toxicon, v. 47, n. 3, p. 313-321, 2006a.

SANDER, E. E.; COLLAR, J. G. Rho-like GTPases: their role in epithelial cell-cell adhesion and invasion. Eur. J. Cancer., v. 35, p. 1905-1911, 1999.

SANO-MARTINS, I. S. et al. Coagulopathy following lethal and non-lethal envenoming of humans by the South American rattlesnake (Crotalus durissus) in Brazil. QJM.., v. 94, n. 10, p. 551-559, 2001.

SCHLIE-WOLTER, S.; NGEZAHAYO, A.; CHICHKOV, B. N. The selective role of ECM components on cell adhesion, morphology, proliferation and communication in vitro. Exp. Cell Res., v. 319, n. 10, p. 1553-1561, 2013.

SHIH, Y. T. et al. Modulation of chemotactic and pro-inflammatory activities of endothelial progenitor cells by hepatocellular carcinoma. Cell Signal., v. 24, n. 3, p. 779-793, 2012. 
SILVA, T. H. A. et al. Agentes antitumorais inibidores da angiogênese - Modelos farmacofóricos para inibidores da integrina $\alpha v \beta 3$. Braz. J. Pharm. Sciences, v. 43, n.1, p. 117, 2007.

SINAN: ACIDENTE POR ANIMAIS PEÇONHENTOS - Notificações registradas no Sistema de Informação de Agravos de Notificação, 2011.

SINGH, A. K. et al. Chemokine receptor trio: CXCR3, CXCR4 and CXCR7 crosstalk via CXCL11 and CXCL12. Cytokine Growth Factor Rev., v. 24, n. 1, p. 41-49, 2013.

SINGH, S.; SADANANDAM, A.; SINGH, R. K. Chemokines in tumor angiogenesis and metastasis. Cancer Metastasis Rev., v. 26, p. 453-467, 2007.

SLOTTA, K. H.; FRAENKEL-CONRAT, H. Estudos químicos sobre os venenos ofídicos. 4Purificação e cristalização do veneno da cobra cascavel. Mem. Inst. Butantan, v. 12, p. 505$512,1938$.

SOUSA-E-SILVA, M. C. C.; GONÇALVES, L. R. C.; MARIANO, M. The venom of South American rattlesnakes inhibits macrophage functions and is endowed with anti-inflammatory properties. Mediators of Inflammation, v. 5, p. 18-23, 1996.

STOCKER K. Composition of snake venoms. In: STOCKER, K. F. Medical use of snake venom proteins. Boca Raton, Boston: CRC, 1990. p. 33-56.

TANEN, D. A. et al. Rattlesnake envenomations: unusual case resentations. Arch. Intern. Med., v. 161, p. $474-479,2001$.

VEGA, F. M.; RIDLEY, A. J. Rho GTPase in cancer cell biology. FEBS Letters, v. 582, p. 2093-2101, 2008.

VITAL-BRAZIL, O. Neurotoxins from South American rattlesnake. J. Formosan. Med. Assoc., v.71, p. 394-396, 1972.

WALTER, F. G.; BIDLEN, E. F.; GIBLY, R. L. Envenomations.Crit. Care Clin., v. 5, 353386, 1999.

WANG, X. H. et al. Differential analyses of angiogenesis and expression of growth factors in micro- and macrovascular endothelial cells of type 2 diabetic rats. Life Sci., v. 84, n. 7-8, p. 240-249, 2009.

WEIS, S. M.; CHERESH, D. A. Tumor angiogenesis: molecular pathways and therapeutic targets. Nat. Med., v. 17, n. 11, p. 1359-1370, 2011.

WIECHELMAN, K. J.; BRAUN, R. D.; FITZPATRICK, J. F. Investigation of the bicinchoninic acid protein assay: identification of the groups responsible for color formation. Anal Biochem., v. 175, p. 231-237, 1988.

WILLIAMS, R. L.; COURTNEIDGE, S. A.; WAGNER, E. F. Embryonic lethalities and endothelial tumors in chimeric mice expressing polyoma virus middle $\mathrm{T}$ oncogene. Cell, $\mathrm{v}$. 52, v. 1, p. 121-131, 1988. 
WOLF, K. Collagen-based cell migration models in vitro and in vivo. Semin. Cell Dev. Biol., v. 20, n. 8, p. 931-941, 2009.

WOLF, K. et al. Amoeboid shape change and contact guidance: T-lymphocyte crawling through fibrillar collagen is independent of matrix remodelingbyMMPs and other proteases. Blood, v. 102, n. 9, p. 3262-3269, 2003.

ZAMBELLI, V. O. et al. Crotoxin alters lymphocyte distribution in rats: Involvement of adhesion molecules and lipoxygenase derived mediators. Toxicon, v. 51, p. 1357-1367, 2008.

ZARIC, J.; RÜEGG, C. Integrin-mediated adhesion and soluble ligand binding stabilize COX-2 protein levels in endothelial cells by inducing expression and preventing degradation. J. Biol. Chem., v. 280, n. 2, p. 1077-1085, 2005.

ZHANG, Z. et al. Alpha2beta1 integrin expression in the tumor microenvironment enhances tumor angiogenesis in a tumor cell-specific manner. Blood, v. 111, n. 4, p. 1980-1988, 2008. 